\title{
Airborne Chemical Elements in Spanish Moss
}

GEOLOGICALSURVEY PROFESSIONAL PAPER 574-E

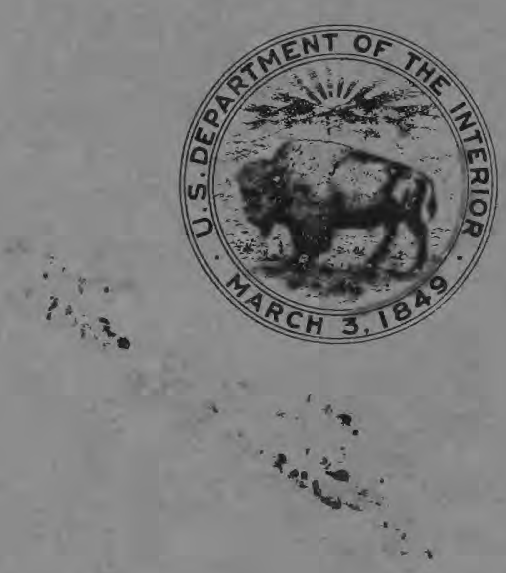




\section{Airborne Chemical Elements in Spanish Moss}

By HANSFORD T. SHACKLETTE and JON J. CONNOR STATISTICAL STUDIES IN FIELD GEOCHEMISTRY

GE O L O I G A L S U R V E P R OFESSIONAL PAPER $574-$ E $A$ study of local and regional variation in airborne materials as indicated by chemical analysis of an epiphyte

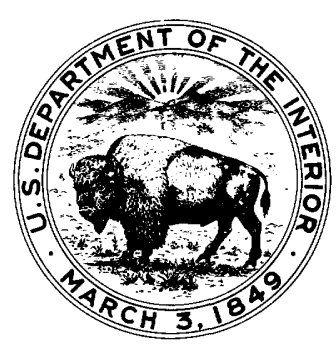




\title{
UNITED STATES DEPARTMENT OF THE INTERIOR
}

ROGERS C. B. MORTON, Secretary

\section{GEOLOGICAL SURVEY}

V. E. McKelvey, Director

\author{
Library of Congress catalog-card No. 73-600178
}

For sale by the Superintendent of Documents, U.S. Government Printing Office Washington, D.C. 20402 - Price $\$ 1.25$ (paper cover)

Stock Number 2401-02456 


\section{CONTENTS}

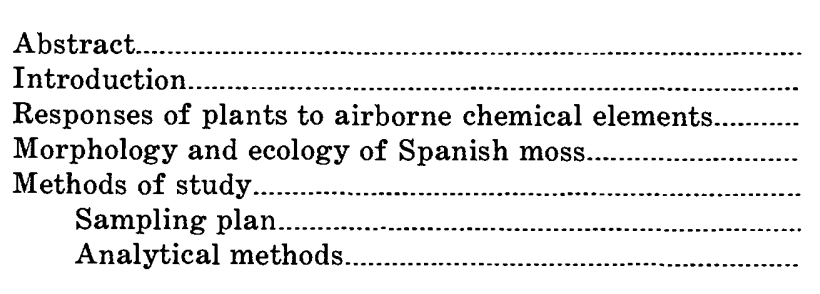

\begin{tabular}{|c|c|}
\hline \multicolumn{2}{|l|}{ Page } \\
\hline E1 & Methods of study - Continued \\
\hline 1 & Data presentation.................... \\
\hline 2 & Elemental composition of Spanish moss........... \\
\hline 3 & 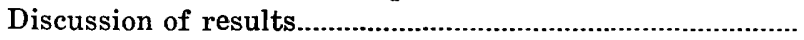 \\
\hline 4 & 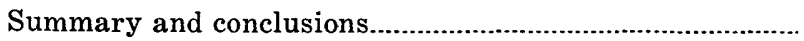 \\
\hline 4 & 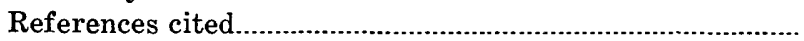 \\
\hline 6 & \\
\hline
\end{tabular}

\section{ILLUSTRATIONS}

Figure

1. Drawings of growth habit and morphological features of Spanish moss (Tillandsia usneoides L.)...

2. Photograph showing growth of Spanish moss on the tops of pond cypress (Taxodium ascendens Brongn.) and on the more shaded lower branches.

3. Map showing Spanish moss sample localities

4. Map showing localities of Spanish moss samples containing elements not commonly detected and the concentrations of the elements.

5-35. Maps showing ash yield and element content of Spanish moss samples:
5. Ash.
6. Aluminum
7. Arsenic
8. Barium
9. Boron
10. Cadmium
11. Calcium...
12. Chromium
13. Cobalt.
14. Copper.
15. Gallium
16. Iron
17. Lanthanum
18. Lead..
19. Lithium.
20. Magnesium
21. Manganese..
22. Molybdenum
23. Nickel
24. Phosphorus
25. Potassium.
26. Scandium
27. Silver.
28. Sodium
29. Strontium
30. Titanium
31. Vanadium
32. Ytterbium
33. Yttrium
34. Zinc
35. Zirconium 


\section{TABLES}

TABLE

1. Spanish moss sample localities and sampling dates...

Page

2. Analytical limits of detection.

3. Chemical composition of Spanish moss samples and samples of soil-rooted plants from the conterminous United States

4. Elements found in concentrations greater than average in Spanish moss samples from four kinds of sites 
STATISTICAL STUDIES IN FIELD GEOCHEMISTRY

\title{
AIRBORNE CHEMICAL ELEMENTS IN SPANISH MOSS
}

\author{
By Hansford T. Shacklette and Jon J. Connor
}

\begin{abstract}
Spanish moss (Tillandsia usneoides L.), collected from its geographic range in Southern United States, was analyzed for 38 chemical elements in 123 samples. Although Spanish moss is an epiphyte and must obtain all of its element load from the atmosphere, most elements in samples of this plant occur in concentrations similar to those of ordinary soil-rooted plants. Analyses of Spanish moss samples collected at rural, residential, highway, and industrial locations reflected significant differences in concentrations of metals. Samples from industrial and highway locations are characterized as containing greater-than-average amounts of arsenic, cadmium, chromium, cobalt, copper, lead, nickel, and vanadium. The high levels of lead found in some samples from highway locations are especially noteworthy. Many samples from sites near the seashore contained greater-than-average amounts of sodium that is thought to have been derived from ocean spray. Samples from rural locations commonly contain low concentrations of the metals usually associated with industrial or urban activity but may contain large amounts of the elements that are ordinary constituents of soil dust. Four of six samples containing detectable amounts of tin were collected within 50 miles of the only tin smelter in the United States; this result suggests that elemental analyses of Spanish moss samples can provide an economical and rapid method of estimating the kind and relative degree of local atmospheric metal pollution.
\end{abstract}

\section{INTRODUCTION}

The importance of airborne materials in affecting the quality of the environment for organisms has prompted many investigators to search for materials and methods most suitable for measuring the concentrations and distribution of these materials. Commonly, the methods consist of various procedures for collecting the airborne materials by filtration and then chemically analyzing the materials, or for continuous instrumental monitoring of gaseous elements or compounds in the air. Recently, however, the degree and extent of airborne contamination have been evaluated by means of observation or chemical analysis of plants that either respond in some visible way to the airborne materials or have the ability to col- lect airborne materials by their physical structures, physiological functions, or both.

The use of suitable plants for measuring concentrations of airborne materials provides the advantages of (1) an integration of the periodic fluctuations in amounts of these materials that occur over relatively long periods of time, and (2) economy in sampling. A disadvantage of using plants, as opposed to filtration or direct monitoring, for this purpose is that analyses of the plants can give estimates only of the relative amounts of airborne materials at different locations, rather than the amounts in a known volume of air.

This study reports the use of Spanish moss (Tillandsia usneoides L.), an epiphyte (commonly called an "air plant") that is common in the Atlantic and Gulf Coastal Plains, for evaluating local and regional variation in airborne materials. Specimens were collected from industrial areas and near major highways, where man-related contaminants were expected to be abundant, as well as from rural areas, where more natural atmospheric burdens were believed to occur.

We thank Messrs. Todd Church, J. A. Erdman, J. R. Keith, R. R. Tidball, and J. D. Vine, of the U.S. Geological Survey, and Messrs. D. B. Ames, W. G. Haag, and Richard Harter, and Mrs. M. A. Erdman for assistance in collecting samples. County Agricultural Extension Agents in each of the States also submitted samples; their cooperation is gratefully acknowledged. Mrs. J. G. Boerngen assisted in computer processing of data, and Mrs. J. M. Bowles prepared the drawings from living plants. All statistical analyses were performed on the U.S. Geological Survey's IBM $360 / 65$ computer and were based on computer programs in the Survey's STATPAC system (Sower and others, 1971). Analyses were made by the following Geological Survey chemists : Leon A. Bradley, Thelma F. Harms, Harriet G. Neiman, Clara S. E. Papp, and James H. Turner. 


\section{RESPONSES OF PLANTS TO AIRBORNE CHEMICAL ELEMENTS}

The effects of excessive concentrations of certain airborne materials on many types of organisms may be either deleterious or beneficial. The responses of plants to airborne toxic substances have been reported many times as evidence of aerial pollution, and the effects of this pollution were reviewed by the European Congress on the Influence of Air Pollution on Plants and Animals (1969).

Some plants, particularly lichens and mosses, are very sensitive to sulfur dioxide (and perhaps other gaseous compounds) in the air. More than a century ago Nylander $(1866$, p. 365) reported [translated], "lichens provide, through their behavior, a measure of the healthfulness of air, and are (one may say) very sensitive "hygiometers." "The sensitivity of both mosses and lichens to air pollution was discussed by LeBlanc (1969). The extent and physiological condition of lichen populations were used to map the degree of pollution in urban and industrial areas by Sloover and LeBlanc (1968).

Many plant species are sensitive to concentrations of airborne fluorine. Symptoms of fluorine poisoning in plants were discussed by Brewer (1966, p. 180-196), and the "normal" fluorine contents of many species were given by Garber $(1968$, p. 42-48) for use in evaluating the extent of fluorine pollution from industrial emissions.

Although additions of extraneous materials to the air generally are considered to be undesirable, increased atmospheric concentrations of certain elements may be beneficial to plants. Ingham (1950) discussed the importance of the mineral content of air and rain to agriculture. Egnér (1965) reviewed the importance to soil fertility of sulfur compounds that are supplied by atmospheric precipitation, and Riehm (1965) described the role of this source in supplying the biologically essential elements calcium, chlorine, boron, potassium, magnesium, nitrogen, and sodium to soils in Europe.

The absorption of atmospheric ammonia by soils in New Jersey was measured by Malo and Purvis (1964). They found that 8.2 pounds of ammoniacal nitrogen per acre was deposited from precipitation in a year, and they believed that nitrogen from this source was a factor in the high yields of maize that was grown without the addition of nitrogen fertilizers from 1958 to 1960 . The direct absorption of atmospheric ammonia by plant leaves was demonstrated by Hutchinson, Millington, and Peters (1972), who stated,

We believe that our data have broad implications in regard to both plant nutrition and air pollution and water pollution control. Calculations [based on their data] indicate that the annual $\mathrm{NH}_{3}$ absorption by plant canopies could be about $20 \mathrm{~kg}$ per hectare. This rate of $\mathrm{NH}_{3}$ supply is large enough to contribute significantly to the nitrogen budget of a growing plant community and could exert a prodigious influence on the long-term behavior of an ecosystem.

Shacklette and Cuthbert $(1967$, p. 42) calculated that the total iodine content of certain soil-rooted plants could be obtained from the exchanges of atmospheric gases that accompany the process of photosynthesis. The total amount of atmospheric iodine added to the soil each year in England was estimated to slightly exceed the amount of iodine removed from the soil in a crop of kale (Chilean Iodine Educ. Bur., 1956).

The "normal" concentration of carbon dioxide in air is generally considered to be about $300 \mathrm{ppm}$ (parts per million), and amounts much greater than this may be considered undesirable for animals. Yet experiments have shown that above-normal concentrations of this gas in the atmosphere increase the growth rate of plants. Holley (1965) found that increasing the carbon dioxide content of the air in greenhouses to as much as $1,000 \mathrm{ppm}$ was economically feasible, and at present the use of carbon dioxide generators is a common practice in the production of some greenhouse crops.

Many other reports have pointed out the importance to land plants of nutrient elements that are obtained directly or indirectly from the atmosphere. However, reports apparently lack conclusive experiments on the relative amounts of certain chemical elements absorbed by land plants from the soil solution, as opposed to amounts of these elements absorbed directly from the atmosphere (Shacklette and Cuthbert, 1967, p. 41). The problem of element source does not arise in discussing Spanish moss because this plant obtains all nutrients from atmospheric gases, precipitation, and airborne particulate matter.

Most kinds of airborne materials cause no apparent damage to plants that are subjected to them. However, the plants may respond by accumulating large amounts of certain of these materials either within the tissues, in deposits on the surfaces of the plants, or both. Ordinary terrestrial plants may incorporate airborne materials into their tissues directly through leaves or indirectly by root absorption of fallout material that accumulates in soils. Wöhlbier $(1968$, p. 142) noted [translated], "Plants take fluorine from the soil by means of their roots, and from the air through the stomates of the leaves." Garber, Guderian, and Stratmann (1968, p. 41) concluded [translated],

The variation in fluorine enrichment in plants from experi- 
mental soil that has not been polluted is insignificant in comparison with the possible enrichment through fluorinecontaining air pollution. Therefore, analyses of the fluorine content of plants can be of consequence as an important adjunct in diagnosing the effects of fluorine in areas of airborne industrial emissions.

The mechanisms of element absorption by, or fixation on, leaves and stems of plants are not fully understood; doubtless, the mechanisms vary greatly, depending on elements and plant species. Generally, the amounts of airborne substances absorbed and incorporated in the plant tissue cannot be distinguished from the amounts held only on the surfaces of leaves and stems. Washing the samples with water or other solvents may remove some of the surficial deposits that are not firmly bound to the plant surfaces. Goodman and Roberts (1971, p. 298) reported, Earlier experiments clearly showed that it was not possible to wash any significant amounts of metals either from moss samples or grass material when it was obtained outside the moss desert [an area so heavily polluted from atmospheric fallout that mosses could not grow in it]. Grass samples taken inside the desert, however, bore significant quantities of washable metals. *** as much as $45 \%$ of analysed metals could be removed by washing.

MacIntire, Hardin, and Hester (1952, p. 1368) found analyses of Spanish moss useful in measuring relative degrees of atmospheric fluorine at different locations, but they did not determine whether the increases in fluorine content in the experimental plants were due to metabolic functions of the plants or to chemical or physical fixation on the plant. In a study of air pollution as measured by analysis of the moss Hypnum cupressiforme, Goodman and Roberts $(1971$, p. 291) stated,

Further information is, however, required about the relative bonding energies of the metals on the exchange surfaces of Hypnum and the modifying influences of rainfall $\mathrm{pH}$. It is also important to know the relative contribution to uptake made by dry deposition (sedimentation and diffusion of various particle sizes) and wash-out processes by rainfall.

Practical applications of the pronounced ability of mosses and lichens to accumulate airborne contaminants have been made recently in Europe. By analyzing specimens of the mosses Hylocomium splendens, Pleurozium schreberi, and Hypnum cupressiforme that were preserved in the Botanical Museum in Lund, Sweden, and that had been collected at intervals from 1860 to 1968 from the same locations, Rühling and Tyler (1968) were able to record the effect of human activity on the concentration of atmospheric lead. They wrote $(1968$, p. 321), "From values of c. $20 \mathrm{ppm}$ [dry weight basis] in the years 1860-1875 the concentration of lead was more than doubled between 1875 and 1900. During the first half of the 20th century no measurable changes were observed, but after about 1950 there was a new strong increase to a present average of c. $80-90$ ppm." Rühling and Tyler $(1968,1969,1971)$ and Rühling $(1969,1971)$ conducted studies of regional distribution of other airborne heavy metals by analyzing samples of mosses and other plants, and they found this method effective in evaluating aerial pollution.

Jaakkola, Takahashi, and Miettinen (1971) analyzed specimens of a lichen (Cladonia alpestris) to measure the airborne cadmium that was released by a recently constructed zinc refinery in Finland. Goodman and Roberts (1971) used samples of the moss Hypnum cupressiforme to measure the airborne heavy metals in some industrial areas in Wales. They concluded (1971, p. 291), "Our methods are much more rapid, inexpensive, and probably more meaningful than spot-sampling of air by filtration, for which prohibitive resources are needed for a few months' operation."

\section{MORPHOLOGY AND ECOLOGY OF SPANISH MOSS}

Certain morphological features of plants enhance their ability to accumulate airborne materials ; therefore, as the physical structures among different species vary, so do responses to airborne materials. Osburn (1963) found moss and lichen mats to be effective filters of radioactive fallout in snow melt water in the Rocky Mountains. In a study of radionuclide fallout from the atmosphere, Watson, Hanson, Davis, and Rickard (1966) stated, "Direct foliar interception by plants is regarded as one of the principal sources of contamination from fallout materials. *** Foliar surface area and plant density are therefore important factors requiring consideration in evaluating fallout accumulation." In the same study the writers pointed out (p. 1176) that greater accumulations of atmospheric fallout occur in plants (1) with persistent above-ground parts (perennial plants), (2) capable of obtaining water and nutrients from the atmosphere, and (3) having great absorptive characteristics. Mosses, lichens, Spanish moss, and certain other plants have all these attributes; moreover, Spanish moss has the advantage, for use in evaluating the kind and amount of airborne materials, of having no roots or rootlike organs and hence of having no direct contact with the soil.

Results of chemical element analyses of plant samples are expressed, on the basis of weight, as the proportion of the element of concern in relation to the total sample. Therefore, plants with a great foliar surface in proportion to their weight tend to accumulate greater concentrations of elements from 
the air than do other plants because their large surface area favors increased absorption and surface deposition of the airborne materials. Thin, small, numerous, and finely divided stems and leaves (or stemlike and leaflike organs, as occur in lichens) are morphological expressions of great surface area relative to the weight of the plant.

Spanish moss is classed as an epiphyte because it most commonly grows on trees. It is not parasitic because it gets all essential elements and water from the air and produces its own food by photosynthesis. It is in the pineapple family (Bromeliaceae), and most species in this family are epiphytes with highly specialized morphological adaptations that assist in obtaining water and other materials from the air. The morphology of this plant was outlined by Garth (1964), who also gave the major references in the literature.

The plant body consists of a sinuous pendant stem that bears curved filiform leaves at nodes on the stem (fig. 1A). The entire plant body, except the flowers and seed capsules, is closely invested with overlapping translucent scales (fig. $1 H$ ), each scale being attached to the stem or leaf at a central point (fig. $1 G$ ). These abundant scales greatly increase the surface of the plant that is exposed to the air. Aso (1909), on the basis of experiments he conducted on lithium nitrate absorption, concluded that salts could pass through the scales into the plant. The ability of the scales to entrap airborne particulate matter is obvious. The scales also assist in water absorption by the body of the plant and contribute to the ability of the plant to withstand drying even when placed in a strong dessicant (Billings, 1904).

Small yellow flowers (fig. $1 B$ ) borne terminally on short branches that arise from leaf axils (fig. $1 A$ ) appear usually in March and April and probably are self-pollinated. The seed capsules (fig. $1 A$ and $C$ ) begin to form in June but do not mature until the following December and January (Garth, 1964). The capsules then open (dehisce), and each releases 10 to 20 seeds (fig. $1 D$ ). Each seed bears a plume of long epidermal hairs (fig. $1 E$ ) that add buoyancy to the seed and enable it to become airborne. If the seed falls on a suitable substrate, such as the rough bark of a tree or a mass of Spanish moss plants, the small barbs at the joints of the hairs (fig. $1 F$ ) assist the seed in adhering to the substrate (Billings, 1904, p. 107). After germination of the seed, rootlike organs (rhizoids) attach the plant to the substrate (fig. 1I) but do not function as absorbing organs (Garth, 1964). These anchoring organs soon degenerate, and the plant is supported only by its densely intertwined stems and leaves.
The factors responsible for the occurrence of Spanish moss at particular locations, and for its regional distribution, are imperfectly understood, although the ecology of the plant has been investigated extensively. In many large areas Spanish moss is extremely abundant and grows on almost any kind of support, whereas in others it occurs at discontinuous locations or is found only closely associated with ponds and streams. It grows on both living and dead trees and in full sun exposure or in shade (fig. 2). Masses of the plants are torn from the supporting trees by winds, and if dropped at suitable locations, they continue growth and establish new colonies. Garth (1964) suggested that the distribution of Spanish moss in the United States is related to major storm paths which arise in Mexico and move laterally over the coastal plains.

The northern limit of the distribution of Spanish moss (fig. 3) is controlled in some manner by seasonal temperatures, although the plant will endure short periods of freezing weather and snowfall. Transplant experiments have proved that it will survive and reproduce at favorable locations as much as 75 miles north of its natural range (Garth, 1964). Its western limit, in east-central Texas, probably is controlled by the frequency of rainfall. Garth (1964) demonstrated that the plant could survive only about 3 to 4 months if deprived of rain, even if natural high humidity was maintained around the plant.

\section{METHODS OF STUDY SAMPLING PLAN}

The collection of samples for this study was begun in 1965 and was continued through 1970 as opportunities arose while we were engaged in other field studies. The general plan was to obtain samples from as many areas as possible at sites spaced about 50 miles apart throughout the range of Spanish moss. In order to obtain samples from some areas that we could not visit, County Agricultural Extension Agents in selected counties were requested to collect and submit samples, and 22 agents responded. In addition, single samples were contributed by several other persons.

Samples were obtained from a wide variety of habitats, including roadsides, industrial and urban areas, remote locations in forests and swamps, ocean beaches, and agricultural areas. Special efforts were made to procure some specimens from sites at the western and northern limits of the plant's range. The samples were pulled from trees or other supports, and visible extraneous matter was removed from the samples before they were placed in cardboard boxes and shipped to the U.S. Geological Survey laboratories in Denver. 

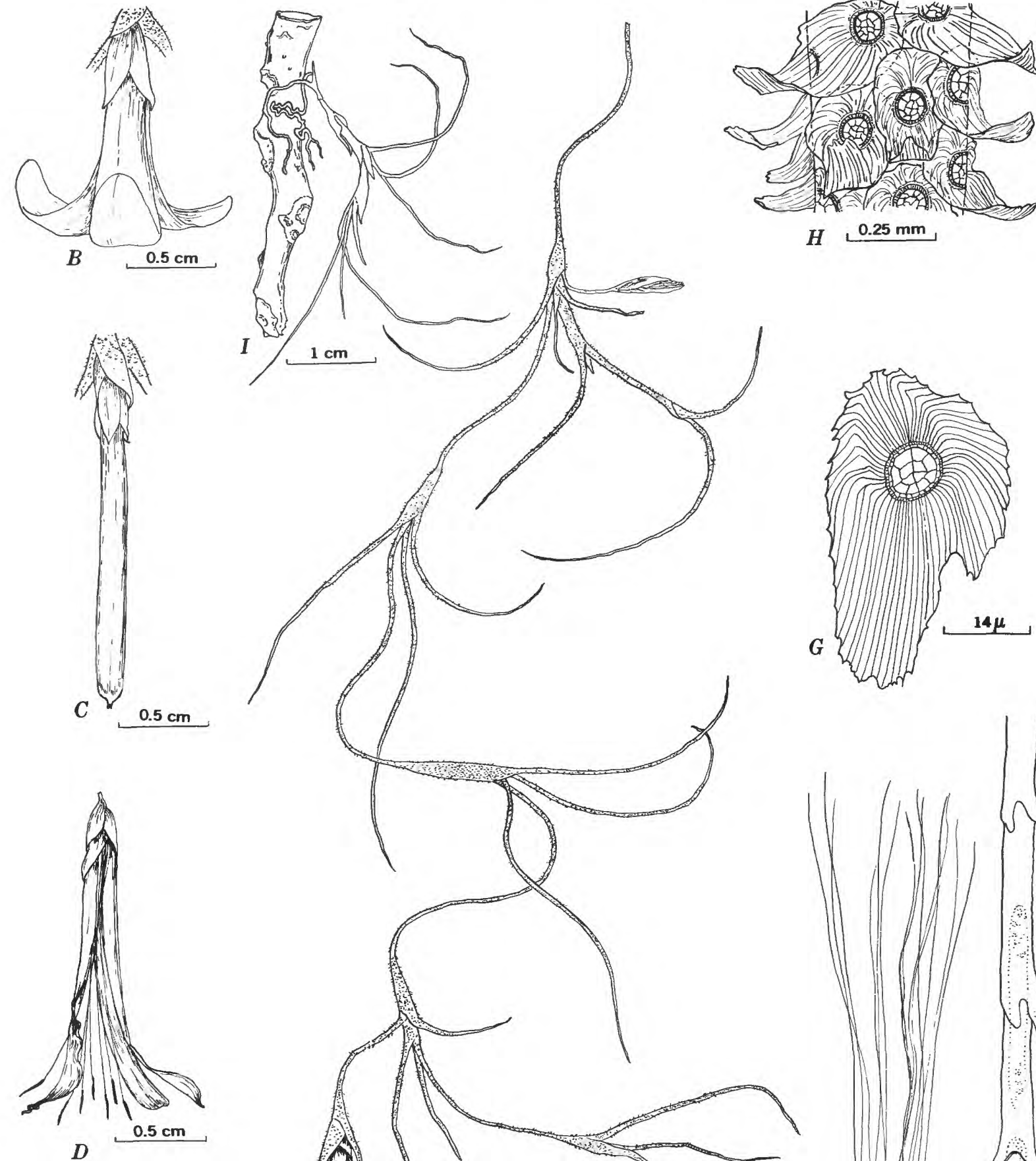

$D$
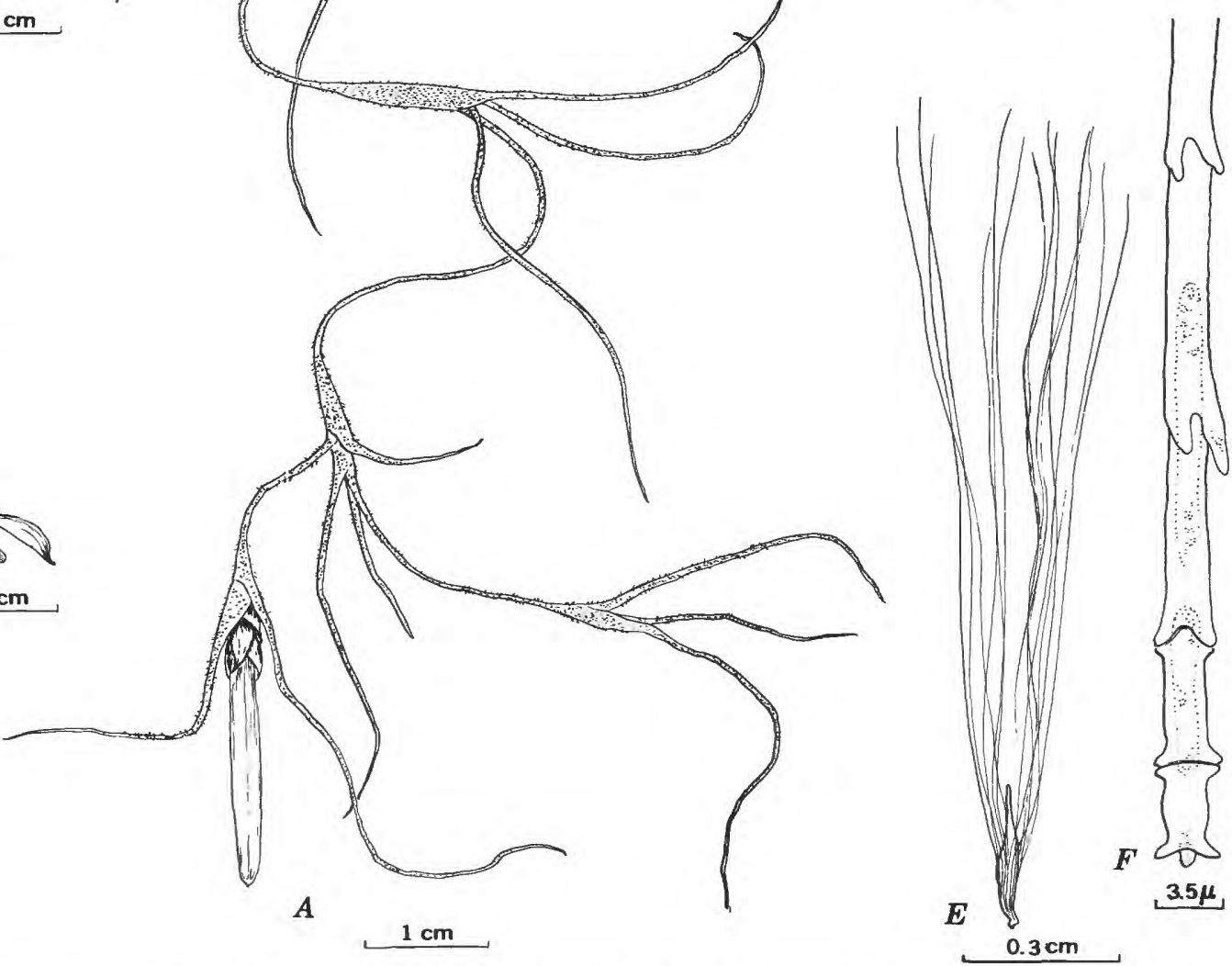

FIGURE 1. - Growth habit and morphological features of Spanish moss (Tillandsia usneoides L.). A, mature plant bearing a seed capsule; $B$, flower; $C$, immature seed capsule; $D$, dehiscence of the mature capsule, which releases the seed; $E$, airborne seed, with plume of epidermal hairs; $F$, distal portion of a single epidermal hair; $G$, a peltate epidermal scale; $H$, portion of stem, showing imbricated translucent scales; $I$, young seedling attached to a branch by means of rhizoids. 


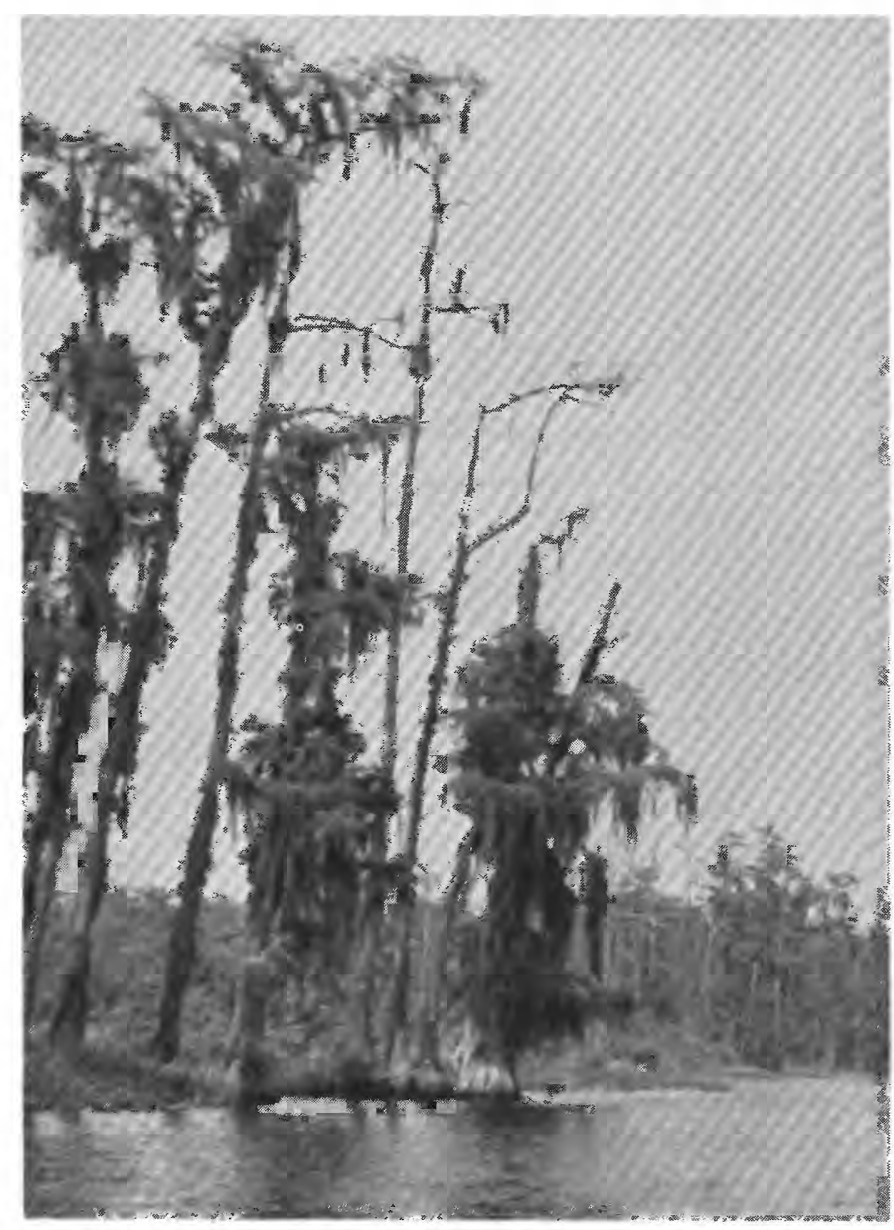

Figure 2. - Growth of Spanish moss on the tops of pond cypress (Taxodium ascendens Brongn.) and on the more shaded lower branches. Okefenokee Swamp, Charlton County, Ga. Photographed July 23, 1963.

The sampling sites are plotted in figure 3 and described in table 1 . All samples were analyzed in the winter of 1970-71. Although the gain or loss of elements during storage of the samples could not be precisely evaluated, we noted no correlation between storage time and concentrations of the more volatile elements.

\section{ANALYTICAL METHODS}

In order to minimize the effects of analytical drift, the samples were arranged in a randomized order before being submitted to the laboratories, and they were analyzed in the same sequence. The unwashed samples were ovendried and then pulverized in a blender. A wet-digestion method was used to prepare the samples for determining their arsenic, mercury, and selenium concentrations. For determining the concentrations of other elements in the samples, portions of the pulverized plants were transferred to ceramic crucibles, weighed, and burned to ash in an electric muffle in which the heat was increased $50^{\circ} \mathrm{C}$ per hour to a temperature of $550^{\circ} \mathrm{C}$ and held at this temperature for about 24 hours. The ash was then weighed to determine the ash yield of the dry plant sample. A colorimetric method was used to analyze the ash for phosphorus content, and an atomic absorption method was used for determining cadmium, calcium, lithium, potassium, sodium, and zinc. Concentrations of the remaining elements in ash were determined by a semiquantitative einission spectrographic method (Myers and others, 1961).

The values obtained by spectrography were reported in geometric brackets having boundaries, in percent, of $1.2,0.83,0.56,0.38,0.26,0.18,0.12$, and so forth; the brackets are identified by their respective geometric midpoints, $1.0,0.7,0.5,0.3,0.2,0.15$, and so forth. Thus, a reported value of 0.3 percent, for example, identifies the bracket from 0.26 to 0.38 percent as the analyst's best estimate of the concentration present. The precision of a reported value is approximately plus or minus one bracket at the 68-percent level of confidence and plus or minus two brackets at the 95-percent level.

The approximate limits of detection of the analytical methods that were used are given in table 2. Some combinations of elements in a sample, however, affect these limits. For example, concentrations somewhat lower than these values may be detected in unusually favorable materials, whereas these limits of detection may not be attained in unfavorable materials.

\section{DATA PRESENTATION}

The concentration of each element in each sample (or its ash) and the location of the corresponding sample site expressed as degrees and minutes of latitude and longitude were entered on automaticdata-processing cards. The analytical values were transformed to logarithms through a computer program which also determined the minimum and maximum values and the basic statistics. In addition, the program reported all occurrences of missing data, indicated the concentrations that were beyond the limits of detection of the analytical methods, and printed both a histogram of the analytical values and an accompanying table of frequencies and cumulative frequencies for each class designation on the histogram.

The table of frequencies could be used to divide the range of reported values into five classes so that as far as possible about 20 percent of the values fell into each class. For some elements the limited ranges in values prohibited use of more than two or three classes to represent the total distribution. Class-in- 


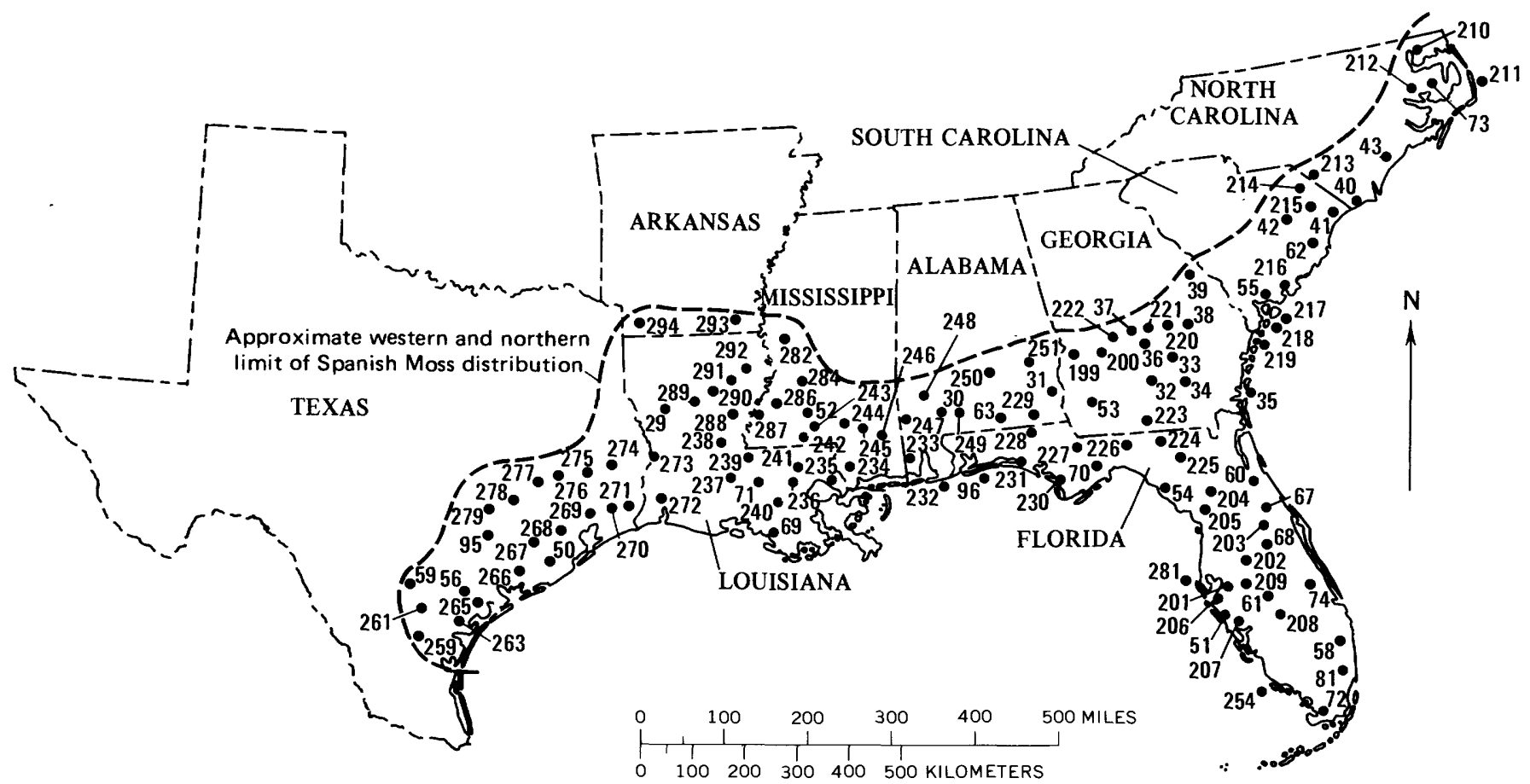

Figure 3. - Spanish moss sample localities (described in table 1). Seashore sites are plotted offshore.

TABLE 1. - Spanish moss sample localities and sampling dates

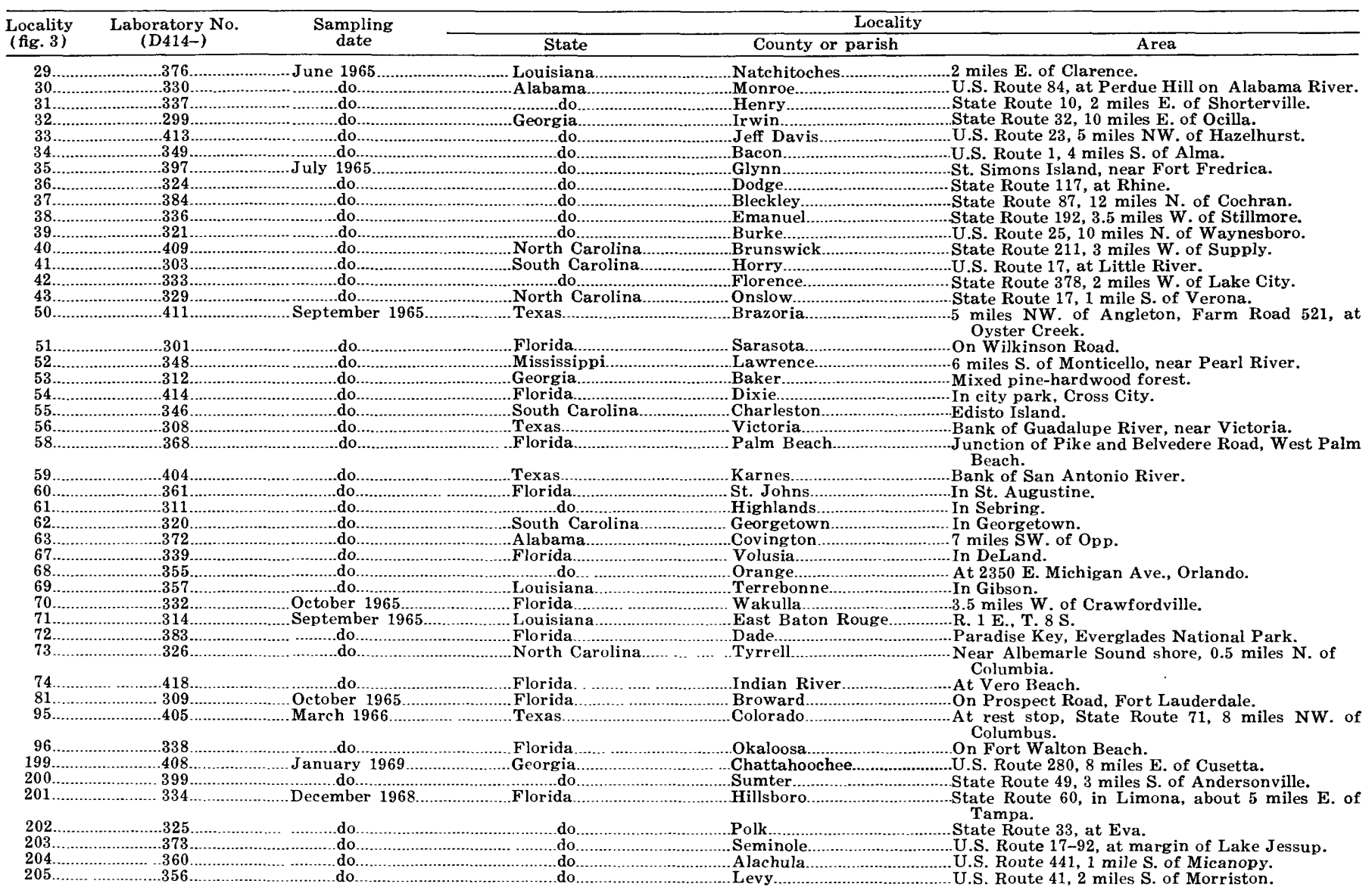


TABLE 1. - Spanish moss sample localities and sampling dates - Continued

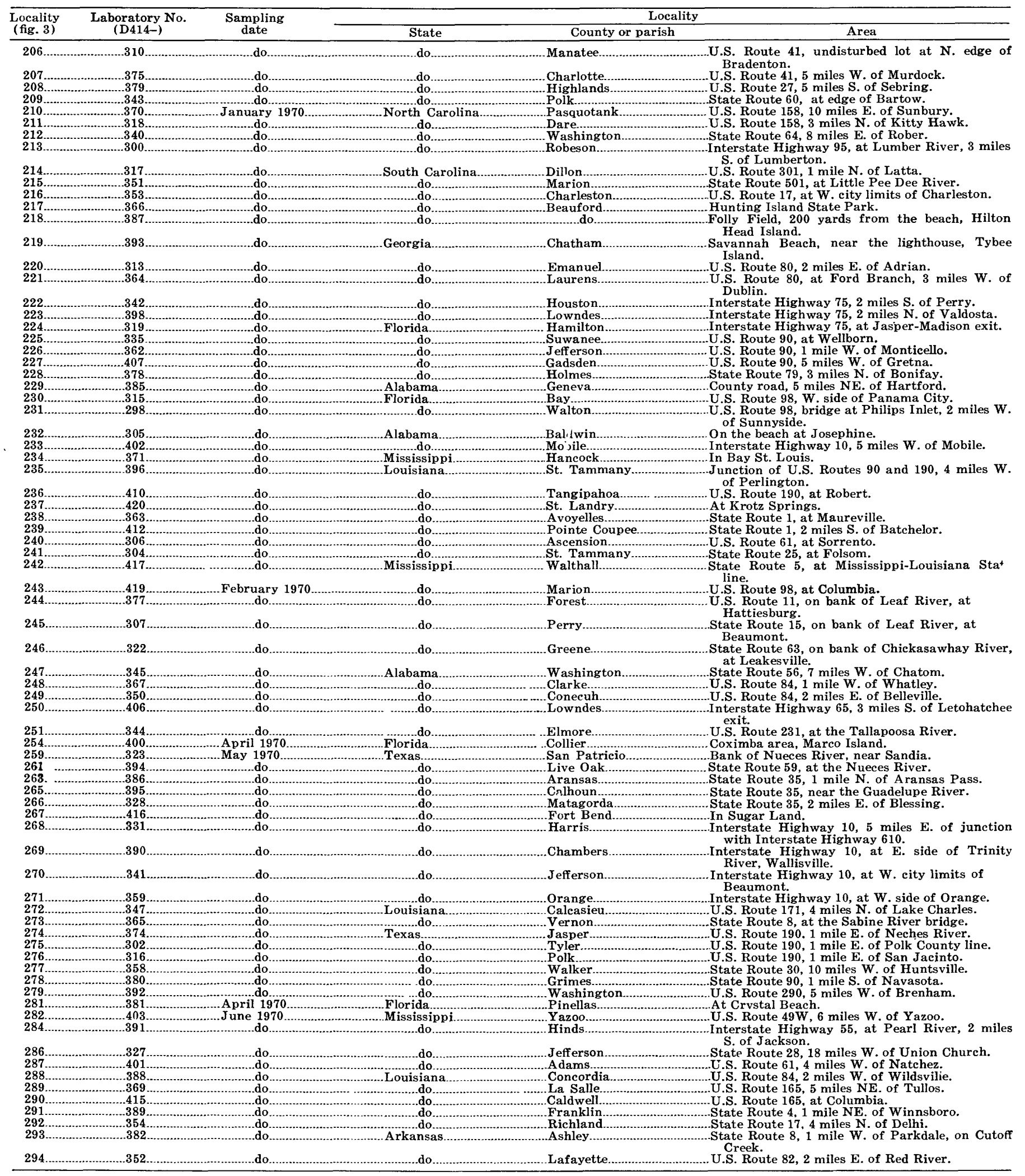


terval code numbers were assigned to each analytical value; these numbers were entered on base maps by an automatic plotter at the proper geographical location of the corresponding sample and then replaced with symbols as shown in figures 5 to 35 .

The geometric means and geometric deviations given in figures 5 to 35 are antilogs of the arithmetic means and standard deviations, respectively, of the logarithms of the analytical values. Where some of the concentrations for an element were determined to be less than the sensitivity of the analytical method (table 2), the means and standard deviations of the logarithms were estimated by means of a censored-distribution technique devised by Cohen (1961). Means estimated by the use of this technique may be lower than the limits of detection for certain elements, as is illustrated by the mean arsenic content of $0.79 \mathrm{ppm}$ in Spanish moss (fig. 7), whereas the limit of detection for arsenic is $1 \mathrm{ppm}$ (table 2). Further discussions of the treatment of censored frequency distributions of geochemical data and of the use of geometric means and geometric deviations were given by Miesch (1967) and Shacklette, Sauer, and Miesch (1970).

All data analysis in this study is based on logarithms of reported concentrations because minor elements commonly tend to exhibit positively skewed frequency distributions. The geometric mean is the best measure of central tendency in log normally distributed data and, as such, is an estimate of the typical or most common concentration for the element. The range from the geometric mean multiplied by the geometric deviation to the geometric mean divided by the geometric deviation generally includes about two-thirds of the analytical values. About 95 percent of the values occur in the range from the geometric mean multiplied by the square of the geometric deviation to the geometric mean divided by the square of the geometric deviation. For example, the geometric mean cadmium content of ash of Spanish moss is $7.9 \mathrm{ppm}$, and the geometric deviation is 1.65 (fig. 10). Thus, probably about two-thirds of a large group of randomly selected samples will have cadmium contents in the range $7.9 \div 1.65=4.8 \mathrm{ppm}$ to $7.9 \times 1.65=13.0 \mathrm{ppm}$, and about 95 percent will have cadmium contents in the range $7.9 \div 1.65^{2}=2.9 \mathrm{ppm}$ to $7.9 \times 1.65^{2}=21.5 \mathrm{ppm}$.

\section{ELEMENTAL COMPOSITION OF SPANISH MOSS}

Chemical analyses of Spanish moss were performed first by Wherry and Buchanan (1926) and later by Wherry and Capen (1928); the analyses indi-
TABLE 2. - Analytical limits of detection

[Analyses made by semiquantitative spectrographic method, except as indicated. Dry plant material was used for arsenic, mercury, and selenium ported in parts per million]

\begin{tabular}{|c|c|c|c|}
\hline Element & $\begin{array}{l}\text { Lower limit } \\
\text { of detection }\end{array}$ & Element & $\begin{array}{l}\text { Lower limit } \\
\text { of detection }\end{array}$ \\
\hline 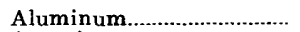 & 20 & 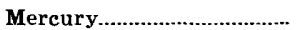 & 10.5 \\
\hline Arsenic & 11 & Molybdenum & \\
\hline Barium & 3 & Neodymium & 150 \\
\hline 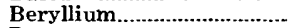 & 2 & Nickel & 10 \\
\hline Boron & 50 & 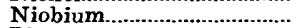 & 20 \\
\hline Cadmium.. & 2.5 & Phosphorus.... & 12 \\
\hline Calcium................................ & 2150 & Potassium. & 250 \\
\hline Cerium & 300 & Scandium..... & 10 \\
\hline Chromium................... & 2 & Selenium.... & 1 \\
\hline Cobalt. & 7 & Silver.............. & 1 \\
\hline Copper..................... & 2 & Sodium......... & ${ }^{2} 100$ \\
\hline 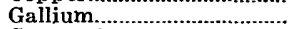 & 10 & 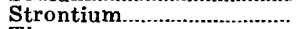 & 10 \\
\hline Germanium & 15 & Tin & 20 \\
\hline Iron & 20 & Titanium......... & 5 \\
\hline Lanthanum. & 70 & Vanadium... & 15 \\
\hline Lead................. & 20 & Ytterbium........................... & 2 \\
\hline Lithium........... & 24 & Yttrium & 20 \\
\hline Magnesium. & 50 & Zinc. & 225 \\
\hline 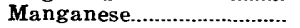 & 2 & 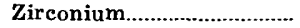 & 20 \\
\hline
\end{tabular}

${ }^{1}$ Analyzed by colorimetric method.

${ }^{2}$ Analyzed by atomic absorption method.

cated that the plant obtains a wide range of chemical elements from the atmosphere. MacIntire, Hardin, and Hester (1952) transplanted specimens of Spanish moss that contained about 27 ppm fluorine in ash when growing in Florida to sites in Tennessee at different distances from factories that emitted fluorine from their stacks. After 3 months the fluorine content of the transplanted specimens ranged from $100 \mathrm{ppm}$ to as much as $2,418 \mathrm{ppm}$ on a dry-weight basis, the amount in the specimen being inversely proportional to the distance of the sample from the factory. Shacklette and Cuthbert $(1967$, p. 43) reported that the iodine content of five Spanish moss specimens averaged $5 \mathrm{ppm}$ in dry matter and ranged from 4 to $7 \mathrm{ppm}$.

Martinez, Nathany, and Dharmarajan (1971) reported lead analyses of eight Spanish moss samples from Baton Rouge, La., from sites near heavily traveled highways and from sites more distant from heavy traffic. They found that the lead concentration was greatest in the samples from sites near highways, with a maximum of 0.085 percent $(850$ $\mathrm{ppm}$ ) in the dry samples, whereas samples from sites more distant from highways contained as little as 0.0051 percent $(51 \mathrm{ppm})$. The percentages of ash obtained by burning the samples were not given; if the ash yield of these samples was similar to the mean ash content of samples analyzed in the present study (4.5 percent of dry weight), their maximum lead concentration would convert to about 18,700 $\mathrm{ppm}$ in ash, and their minimum lead concentrations would convert to about $1,122 \mathrm{ppm}$ in ash. These values are well within the range (70 to $50,000 \mathrm{ppm}$ lead in ash) given in figure 17 of the present report. 
Benzing and Renfrow (1971) analyzed samples of Tillandsia circinata Schlecht., a small epiphyte closely related to Spanish moss. They reported concentrations of the nutritive elements calcium, magnesium, nitrogen, phosphorus, potassium, and sodium in samples of prefruiting, fruiting, and postfruiting plants from six sites in southern Florida. Although considerable variation was found in the concentrations of these elements among sites and growth stages, plants in the prefruiting stage generally contained more potassium, magnesium, and phosphorus than plants in other growth stages. Trends in growth-stage concentrations of the other elements were not pronounced, although the postfruiting stage at one sampling site contained the largest amounts of magnesium, calcium, and sodium.

Shacklette (1972) reported that the cadmium concentrations in the Spanish moss samples discussed in the present report ranged from 2.2 to 27 ppm in ash. The concentrations were thought to be related to the degree and kind of aerial pollution at the locations where the samples grew.

The ash yield and the concentrations of selected elements in the samples of Spanish moss collected in this study are presented in figures 5 to 35 . Sample localities indicated by symbols in these figures are referred to by locality numbers in figure 3 and are described in table 1.

Concentrations of all elements but arsenic, mercury, and selenium (figs. 4-35) are given as parts per million in ash. The percentages of ash obtained by burning the dry samples are given in figure 5 . The parts per million of an element in ash can be converted to approximate parts per million in the dry material by means of the following equation:

Element $(\mathrm{ppm})$ in dry plant $=$ element $(\mathrm{ppm})$ in ash

$$
\times \frac{\text { ash content (percent) }}{100}
$$

The elements beryllium, cerium, germanium, mercury, neodymium, niobium, selenium, and tin were not commonly detected in the samples. The localities where samples containing these elements were collected and the concentrations of the elements in the samrles are shown in figure 4.

Some elements were looked for in all samples but were not found. These elements, analyzed by the semiquantitative emission spectrographic method, and their lower detection limits, in parts per million,

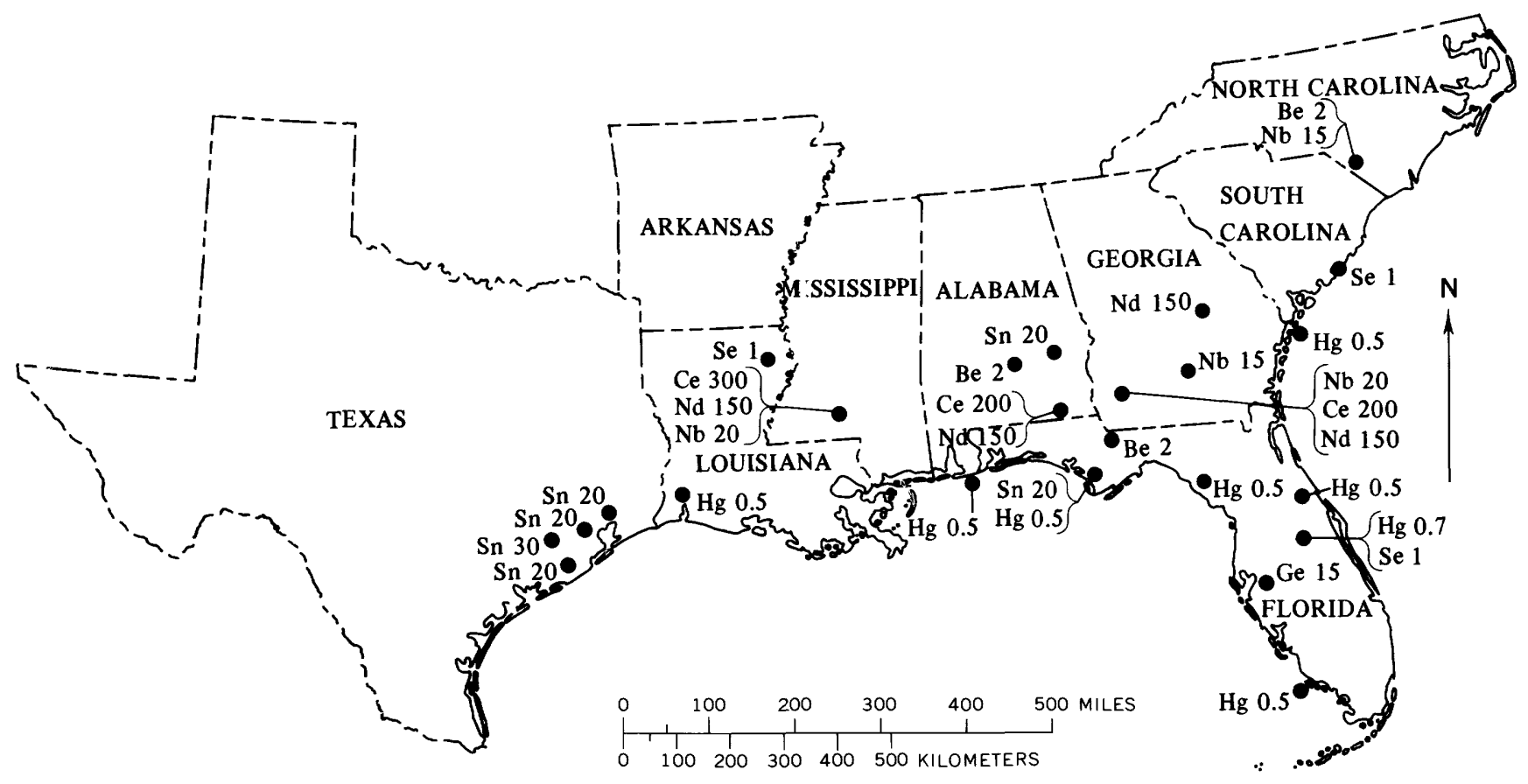

FIGURE 4. - Localities of Spanish moss samples containing elements not commonly detected and the concentrations of the elements. Mercury $(\mathrm{Hg})$ and selenium (Se) values are expressed as parts per million in dry plant material; beryllium $(\mathrm{Be})$, cerium $(\mathrm{Ce})$, germanium $(\mathrm{Ge})$, neodymium $(\mathrm{Nd})$, niobium $(\mathrm{Nb})$, and tin ( $\mathrm{Sn}$ ) values are expressed as parts per million in ash. 
are as follows: Gold, 40; hafnium, 200; indium, 20 ; platinum, 60 ; palladium, 2 ; rhenium, 60 ; tantalum, 400 ; tellurium, 4,000; thallium, 100 ; thorium, 400 ; and uranium, 1,000. If lanthanum or cerium was found in a sample, the following elements, with their stated lower detection limits, were specifically looked for in the same sample: Dysprosium, 100 ; erbium, 100; gadolinium, 100; holmium, 40; lutetium, 60 ; terbium, 600 ; and thulium, 40 . Though looked for, none of these elements was found.
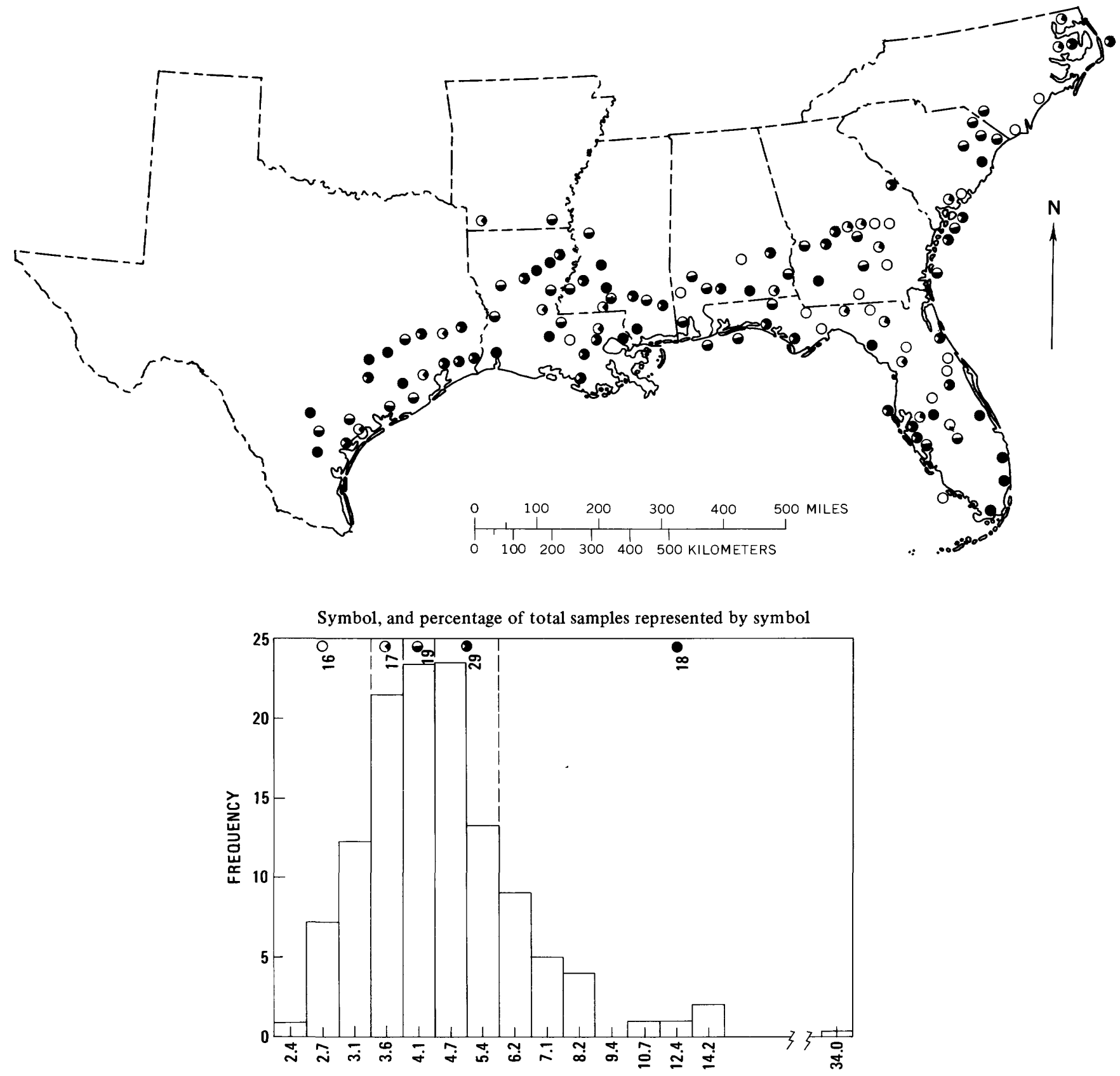

ASH, IN PERCENTAGE OF DRY WEIGHT

Geometric mean, 4.6

Geometric deviation, 1.46

Number of samples and analyses, 123

Figure 5. - Ash yield of Spanish moss. 

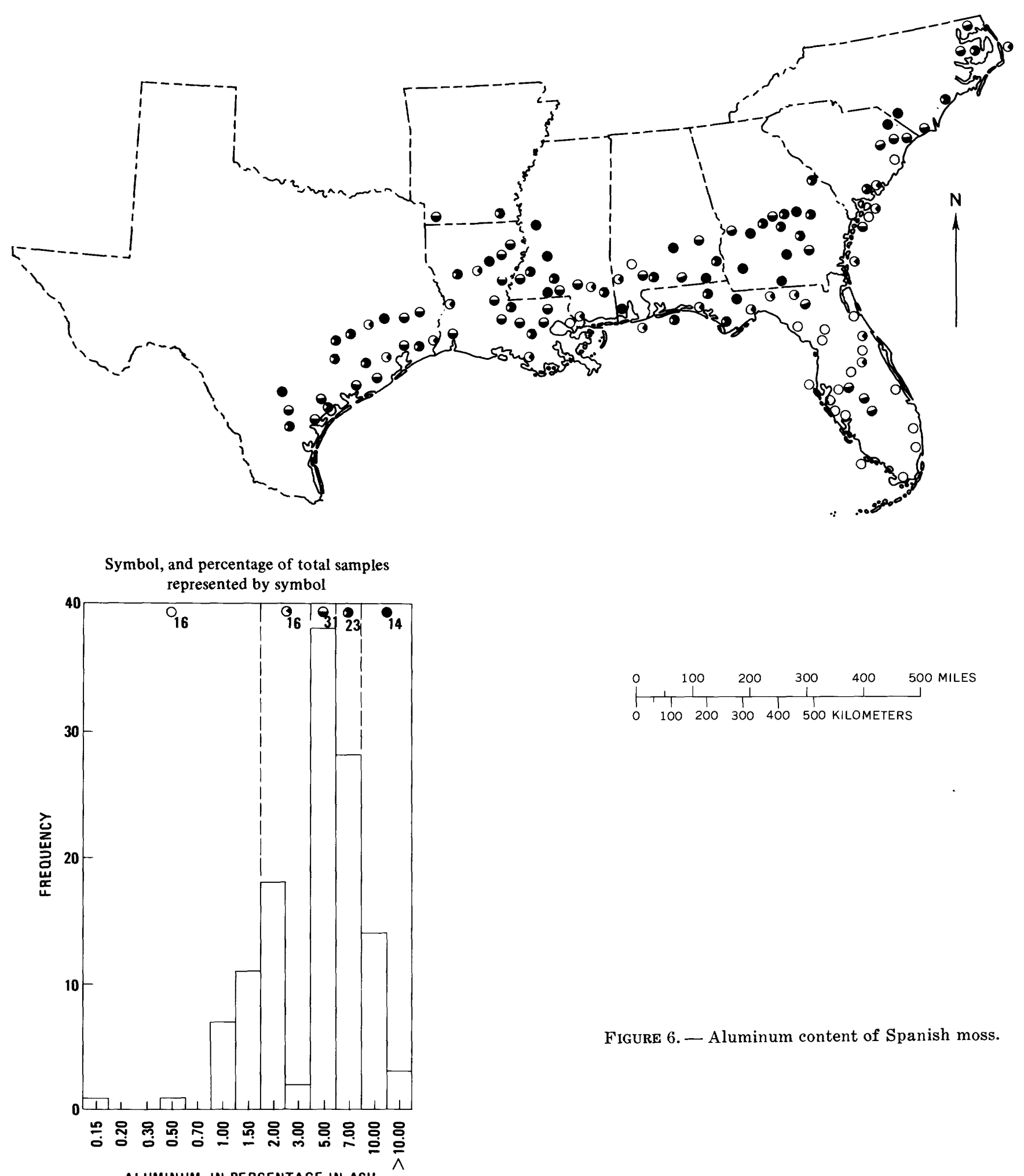

ALUMINUM, IN PERCENTAGE IN ASH

Geometric mean, 4.08

Geometric deviation, 2.21

Number of samples and analyses, 123

Figure 6. - Aluminum content of Spanish moss. 


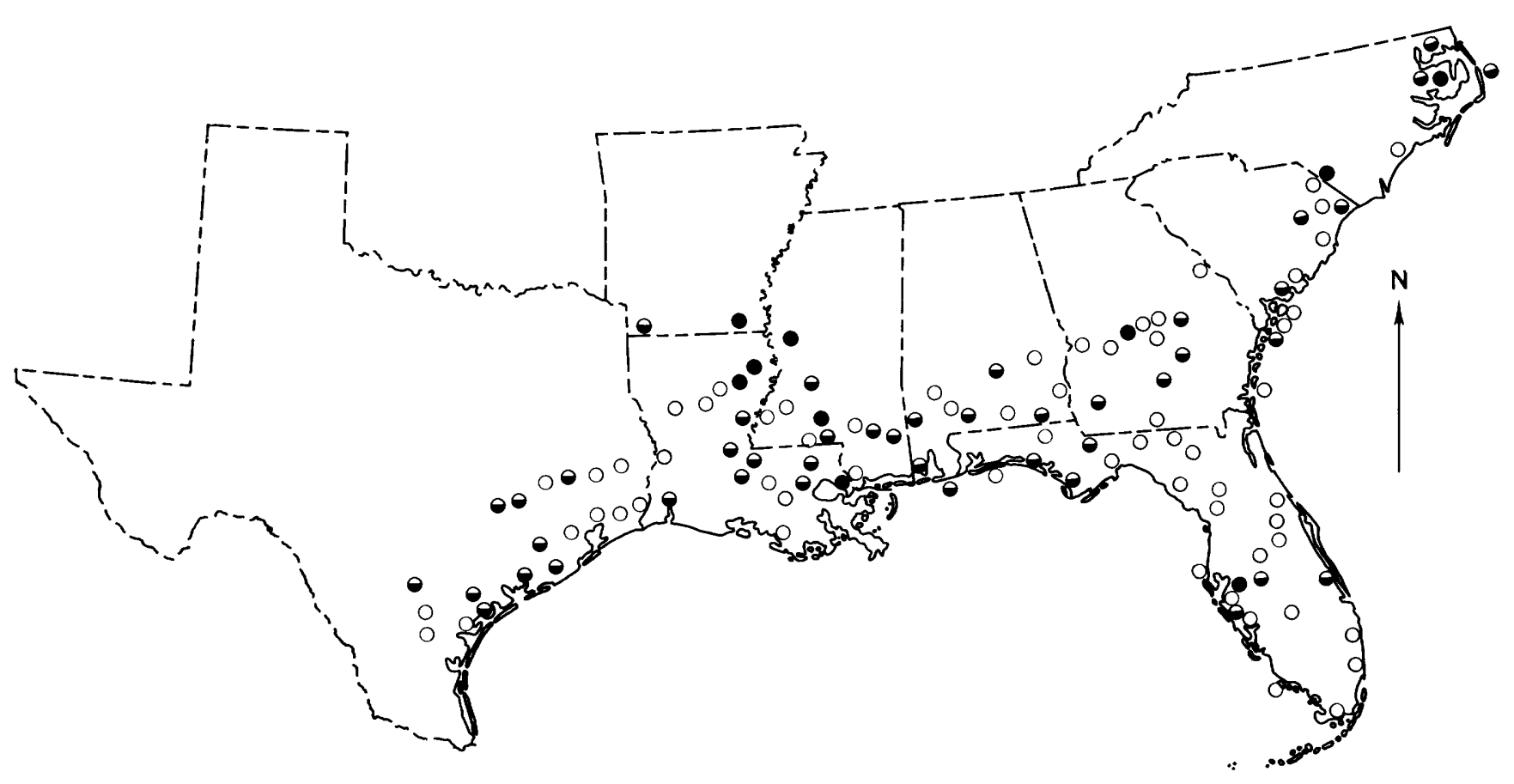

Symbol, and percentage of total samples represented by symbol
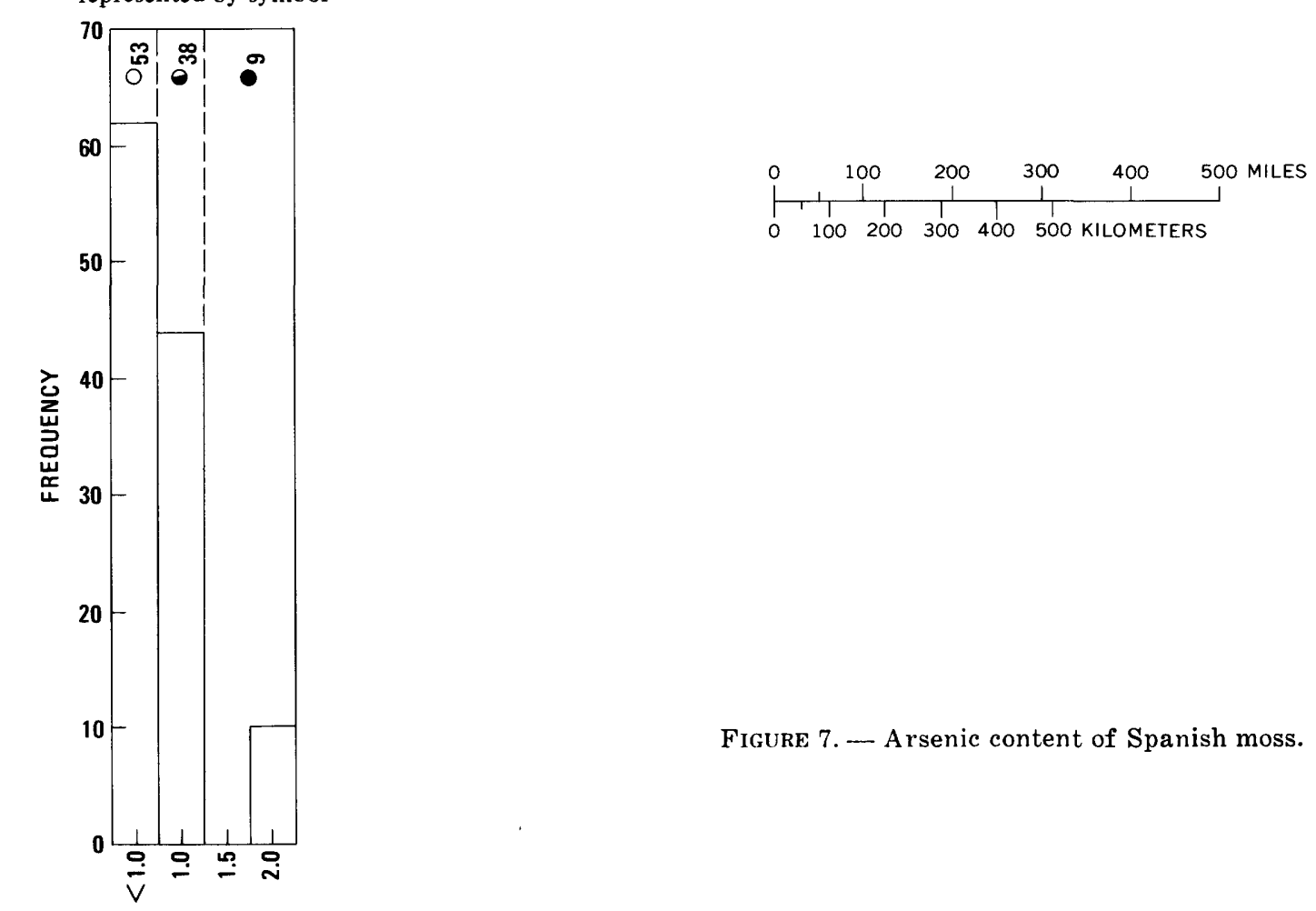

ARSENIC, IN PARTS PER MILLION IN DRY MATERIAL

Geometric mean, 0.79

Geometric deviation, 1.55

Number of samples and analyses, 116 


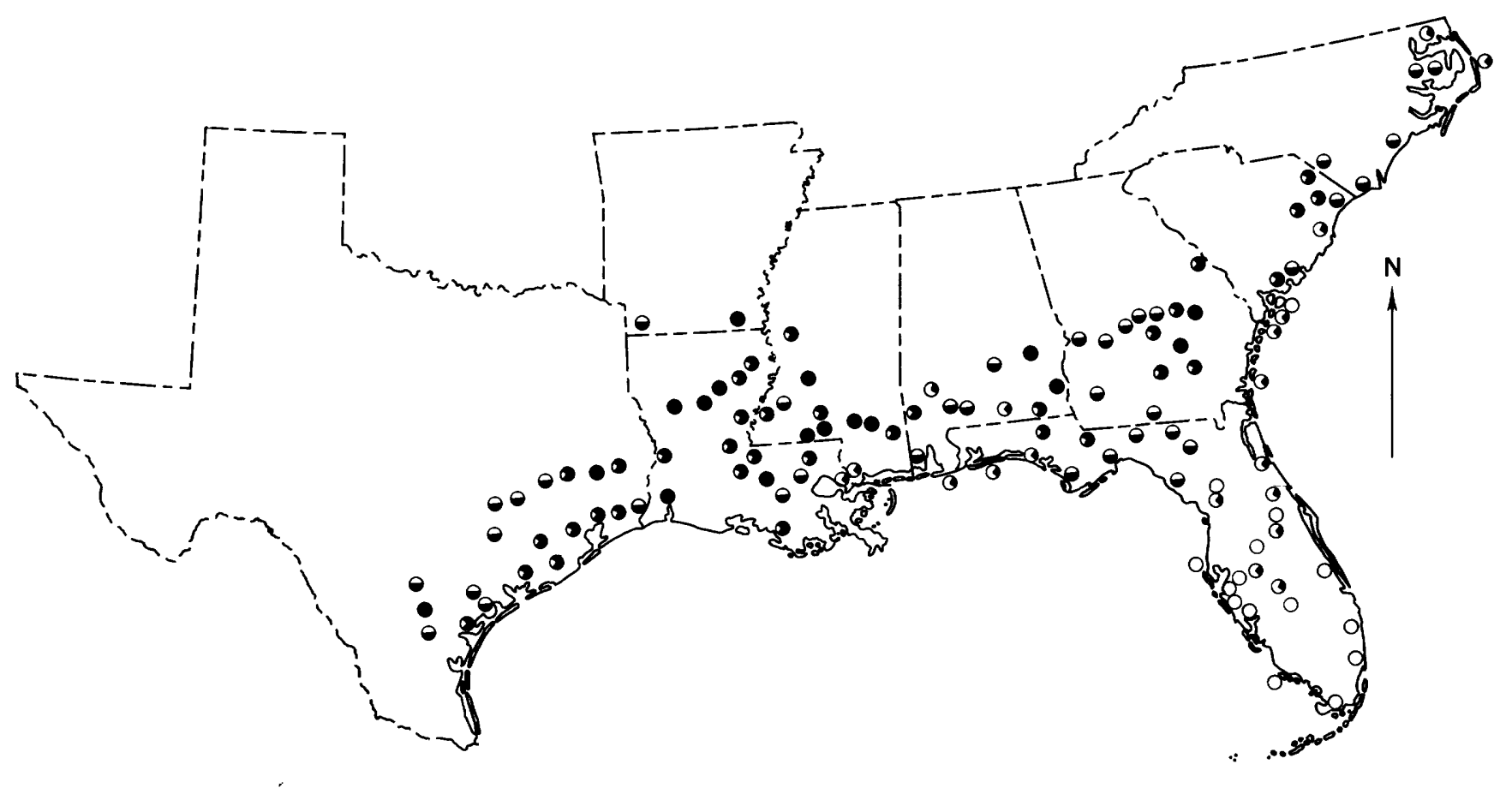

Symbol, and percentage of total samples represented by symbol
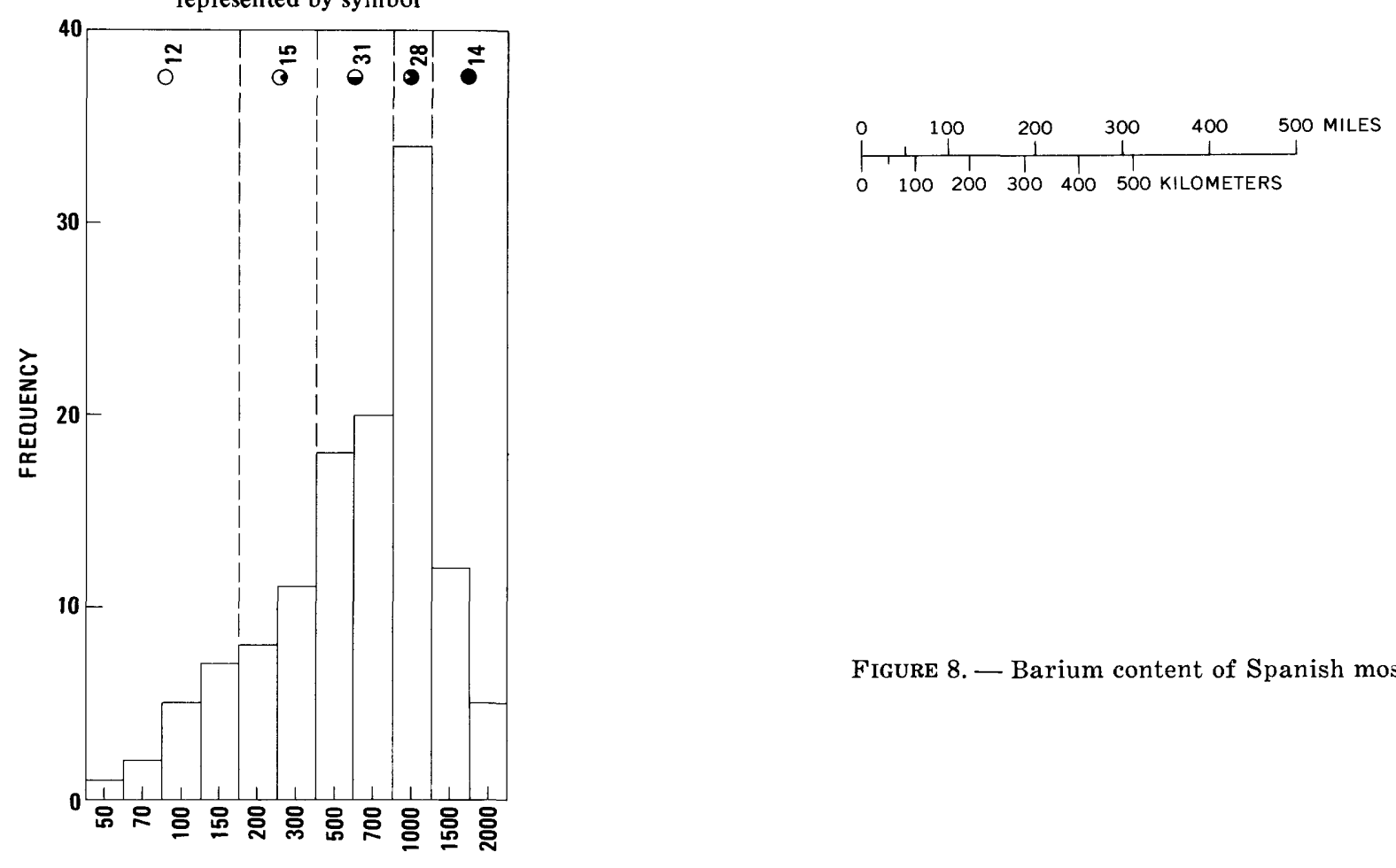

Figure 8. - Barium content of Spanish moss.

BARIUM, IN PARTS PER MILLION IN ASH

Geometric mean, 564

Geometric deviation, 2.32

Number of samples and analyses, 123 


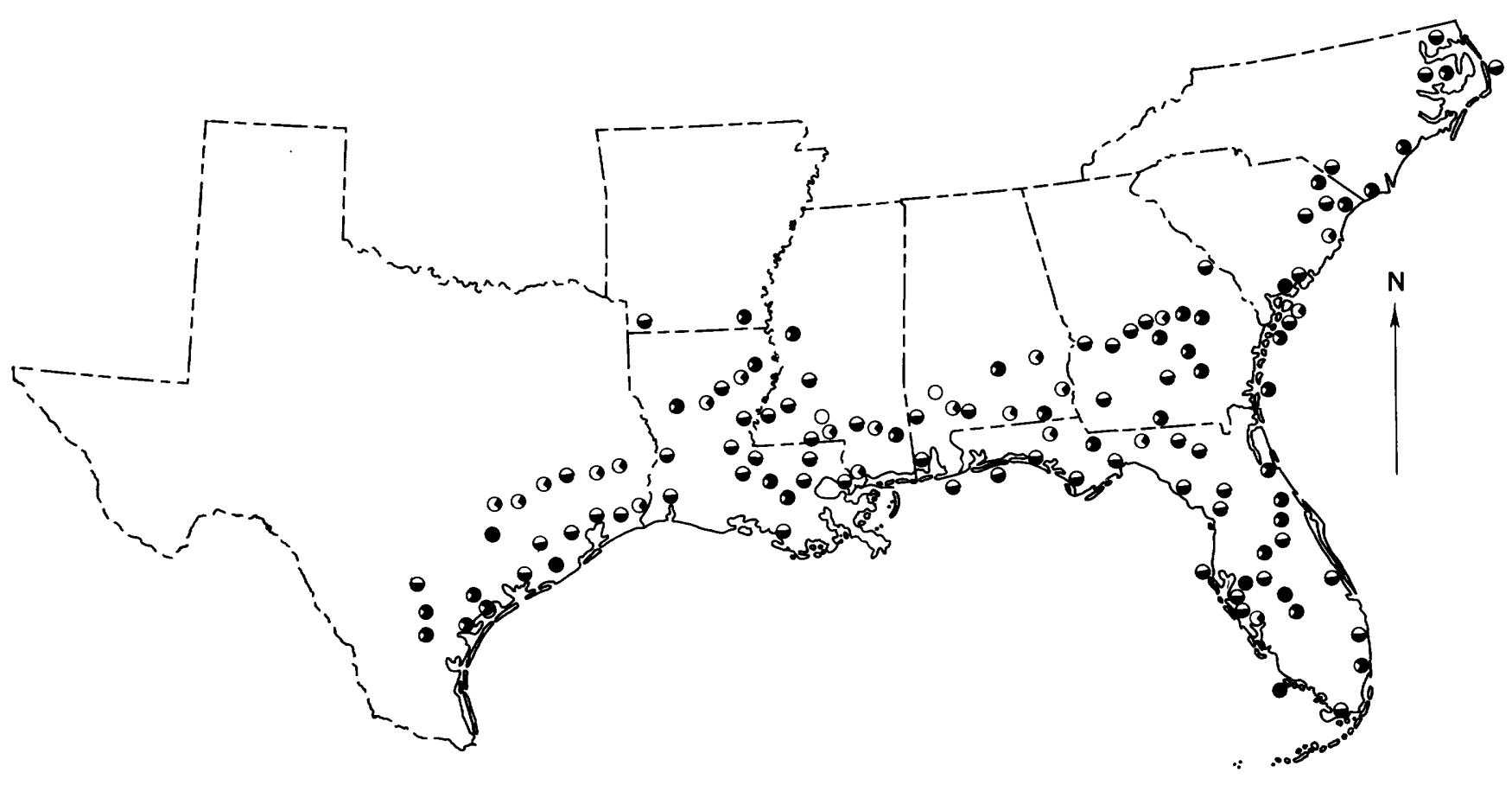

Symbol, and percentage of total samples
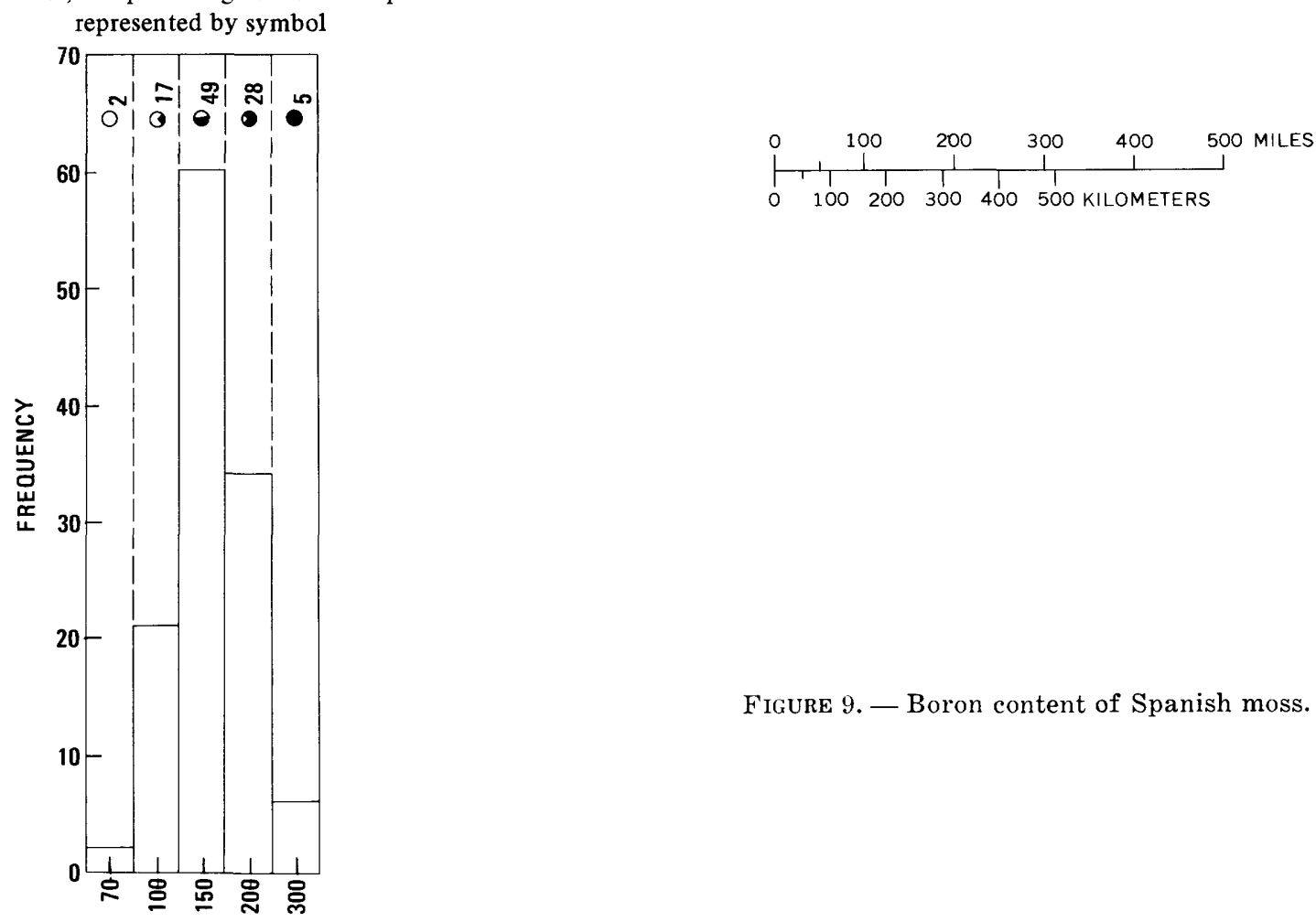

BORON, IN PARTS PER MILLION IN ASH

Geometric mean, 150

Geometric deviation, 1.34

Number of samples and analyses, 123

Figure 9. - Boron content of Spanish moss. 

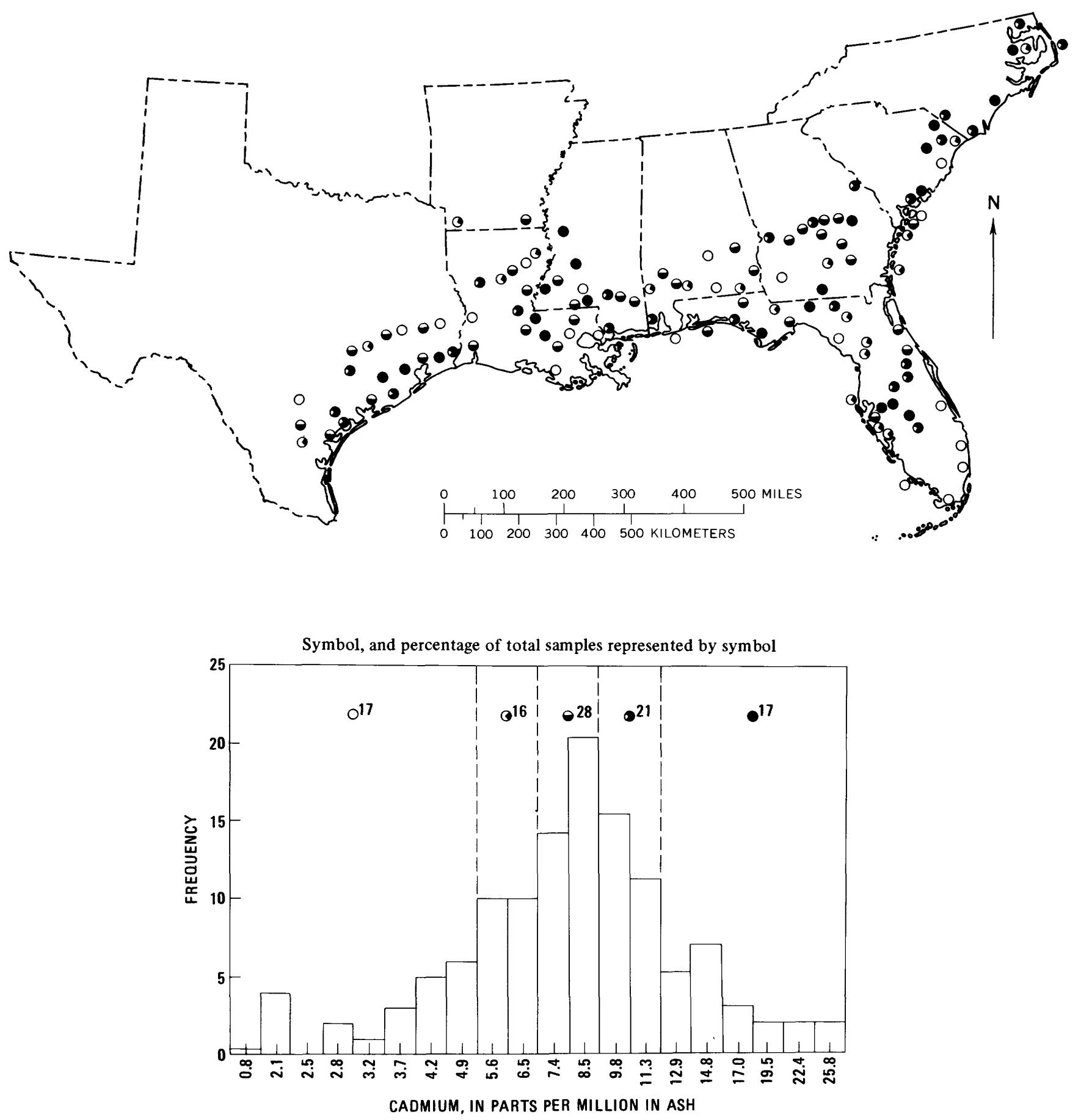

Geometric mean, 7.9

Geometric deviation, 1.65

Number of samples and analyses, 122

Figure 10. - Cadmium content of Spanish moss. 


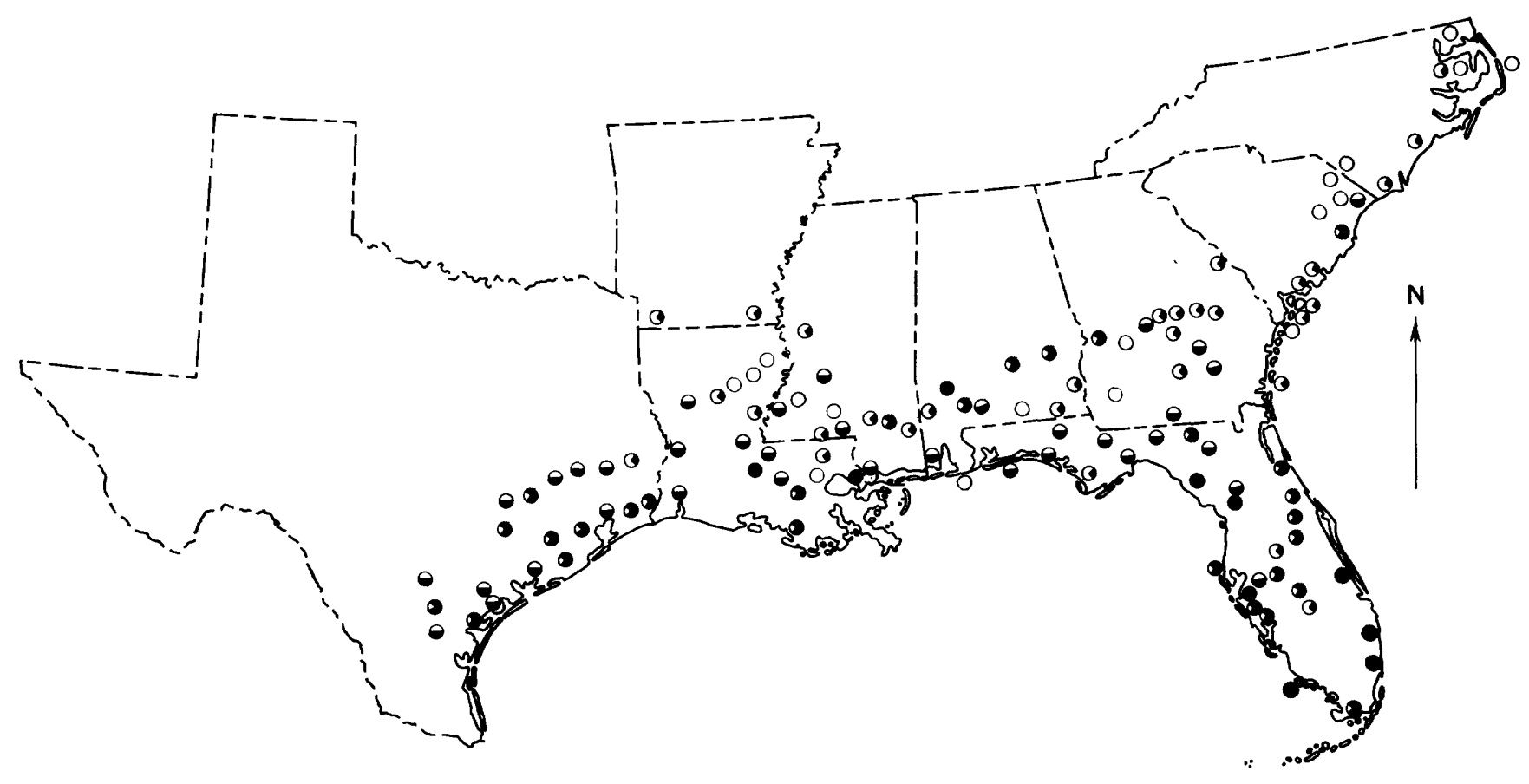

Symbol, and percentage of total samples
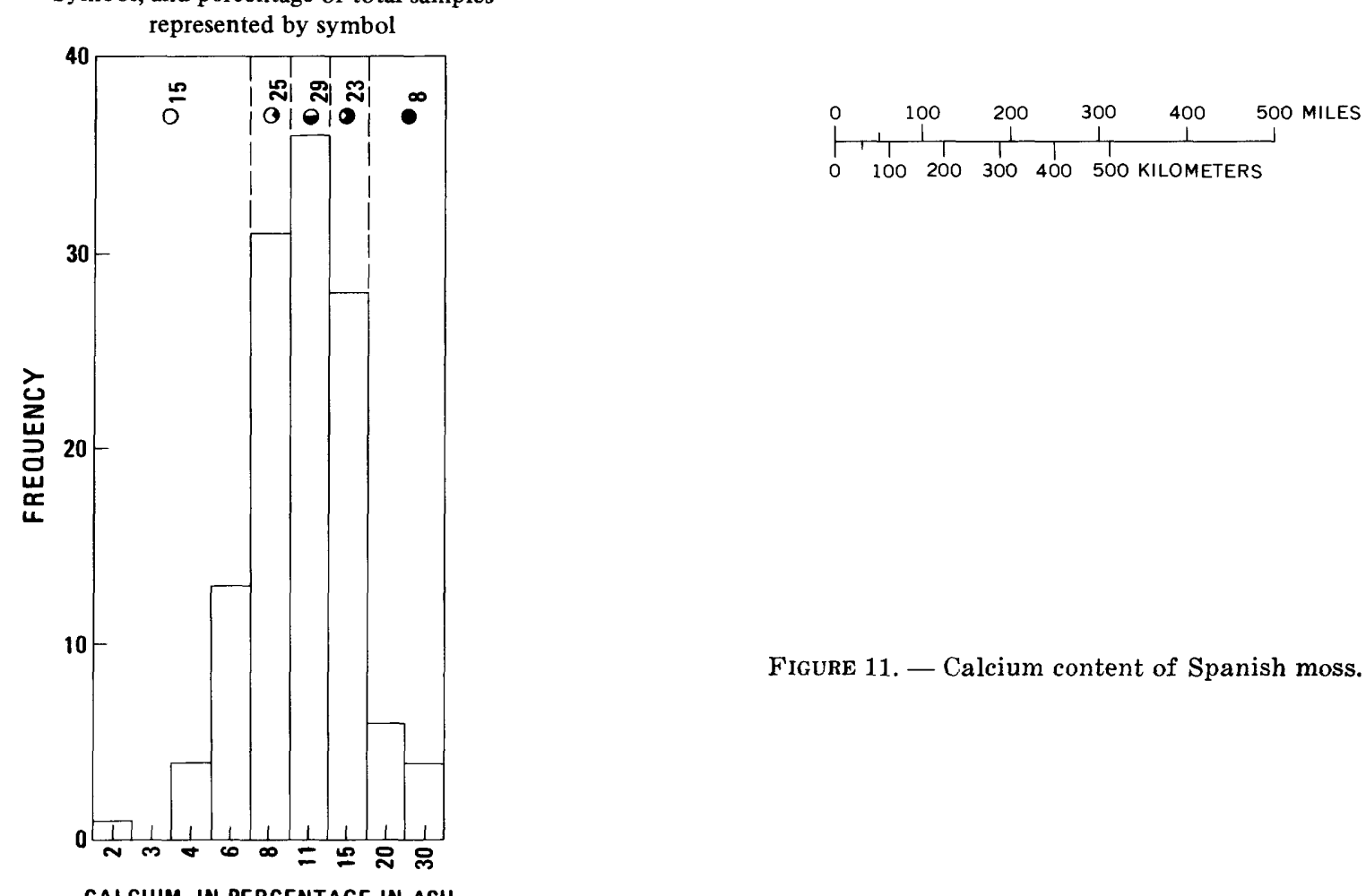

CALCIUM, IN PERCENTAGE IN ASH

Geometric mean, 10.07

Geometric deviation, 1.56

Number of samples and analyses, 123

Figure 11. - Calcium content of Spanish moss. 

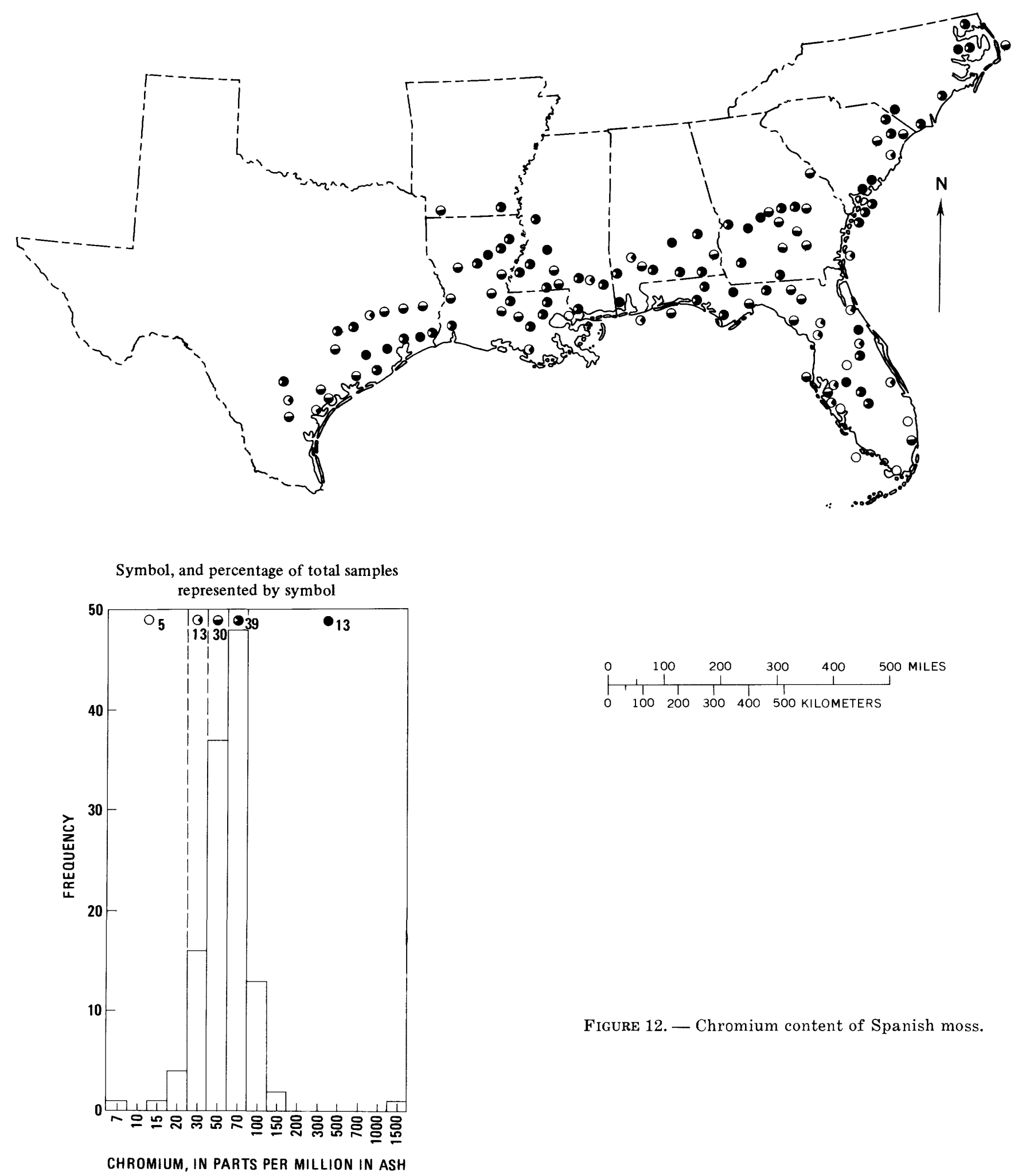

Figure 12. - Chromium content of Spanish moss.

Geometric mean, 57

Geometric deviation, 1.73

Number of samples and analyses, 123 


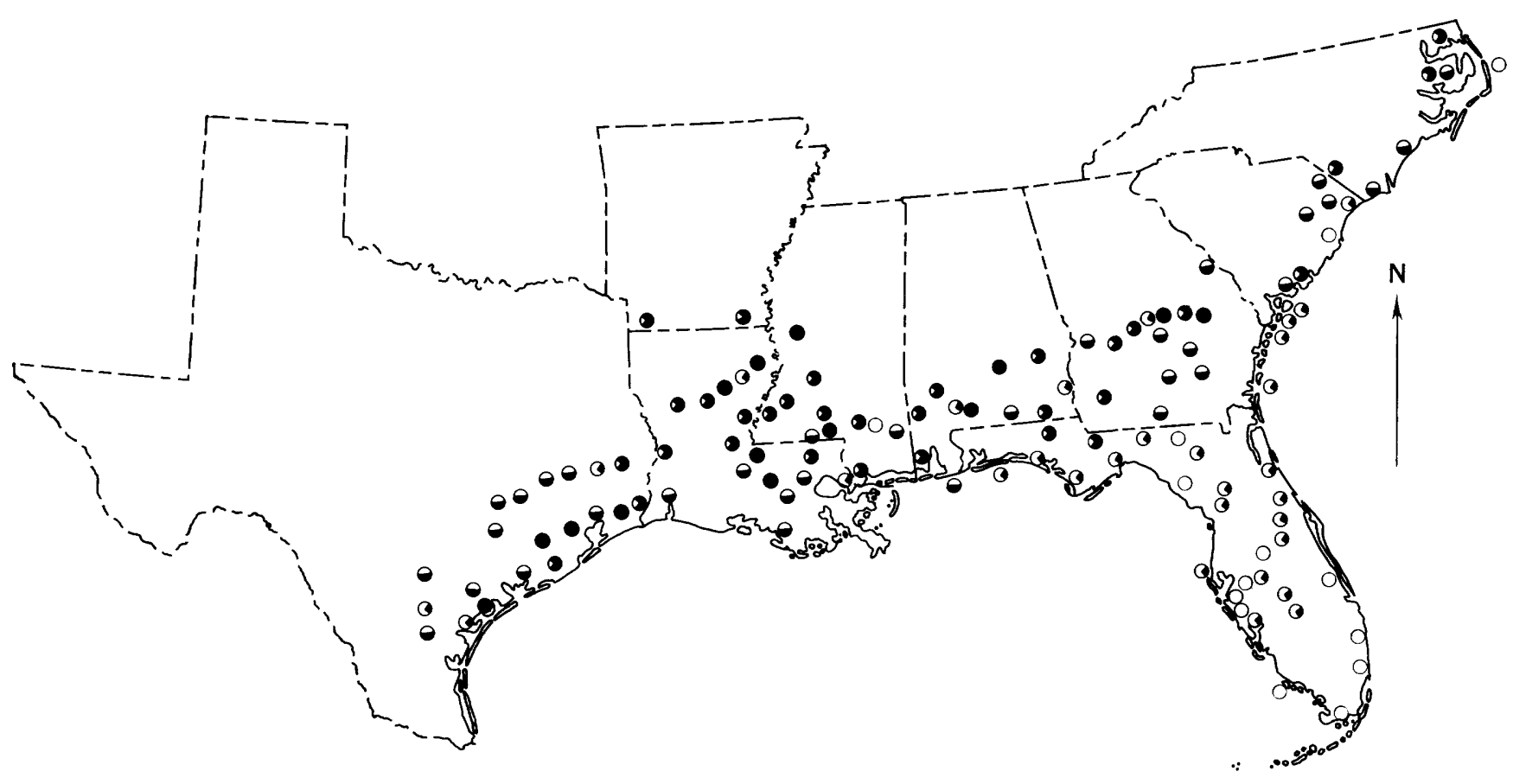

Symbol, and percentage of total samples
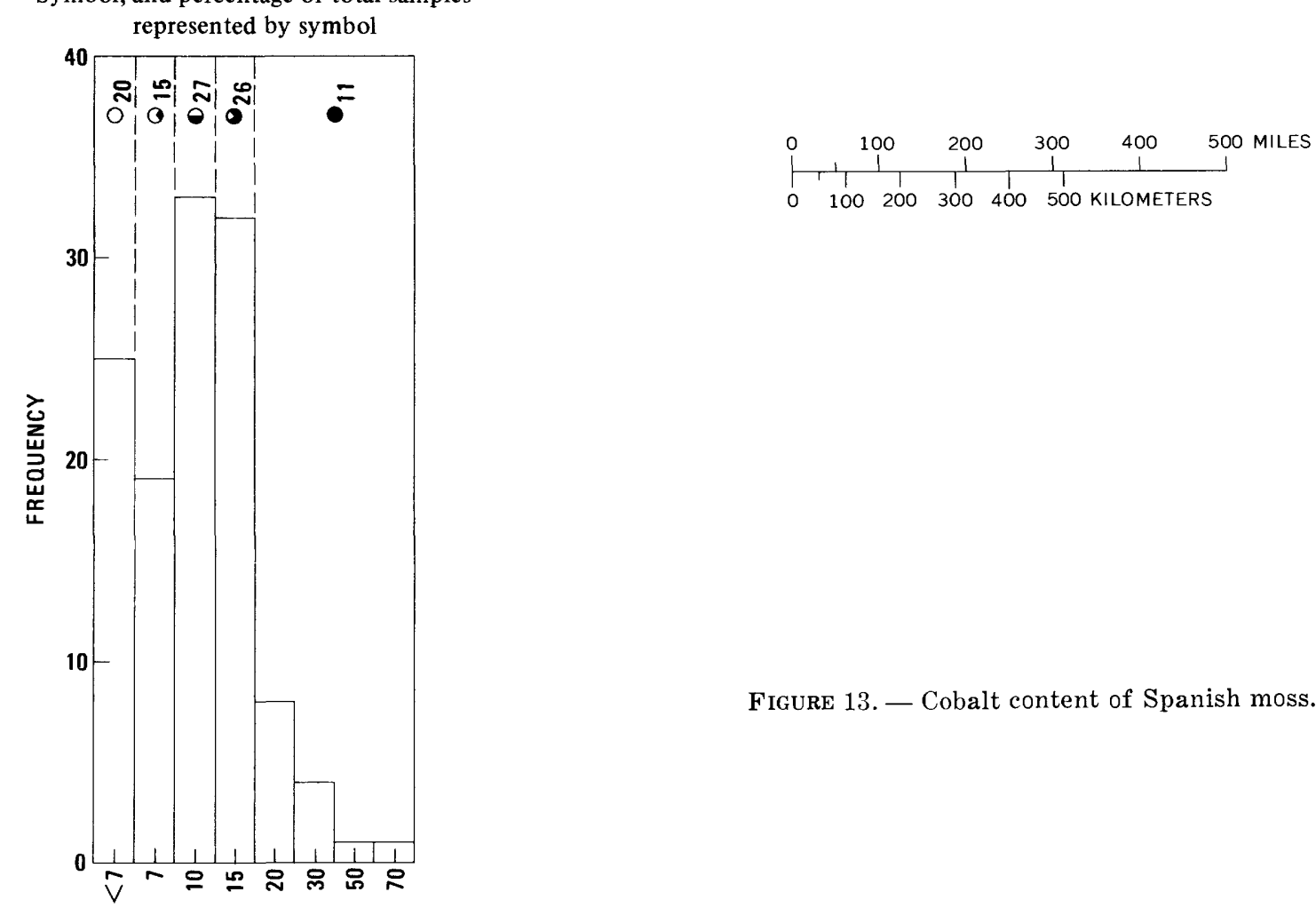

COBALT, IN PARTS PER MILLION IN ASH

Geometric mean, 9.8

Geometric deviation, 1.83

Number of samples and analyses, 123

Figure 13. - Cobalt content of Spanish moss. 

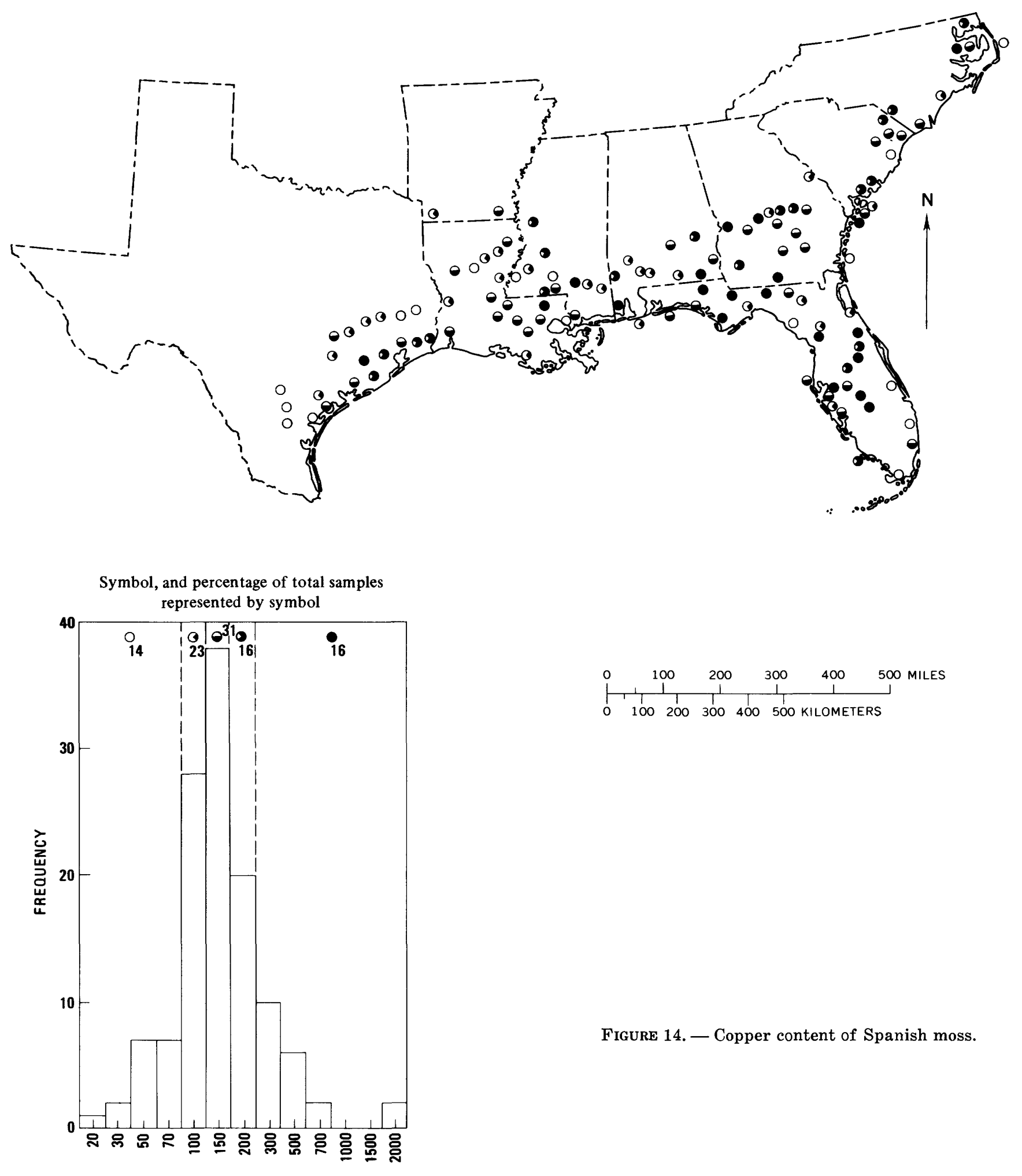

COPPER, IN PARTS PER MILLION IN ASH

Geometric mean, 148

Geometric deviation, 2.01

Number of samples and analyses, 123

Figure 14. - Copper content of Spanish moss. 


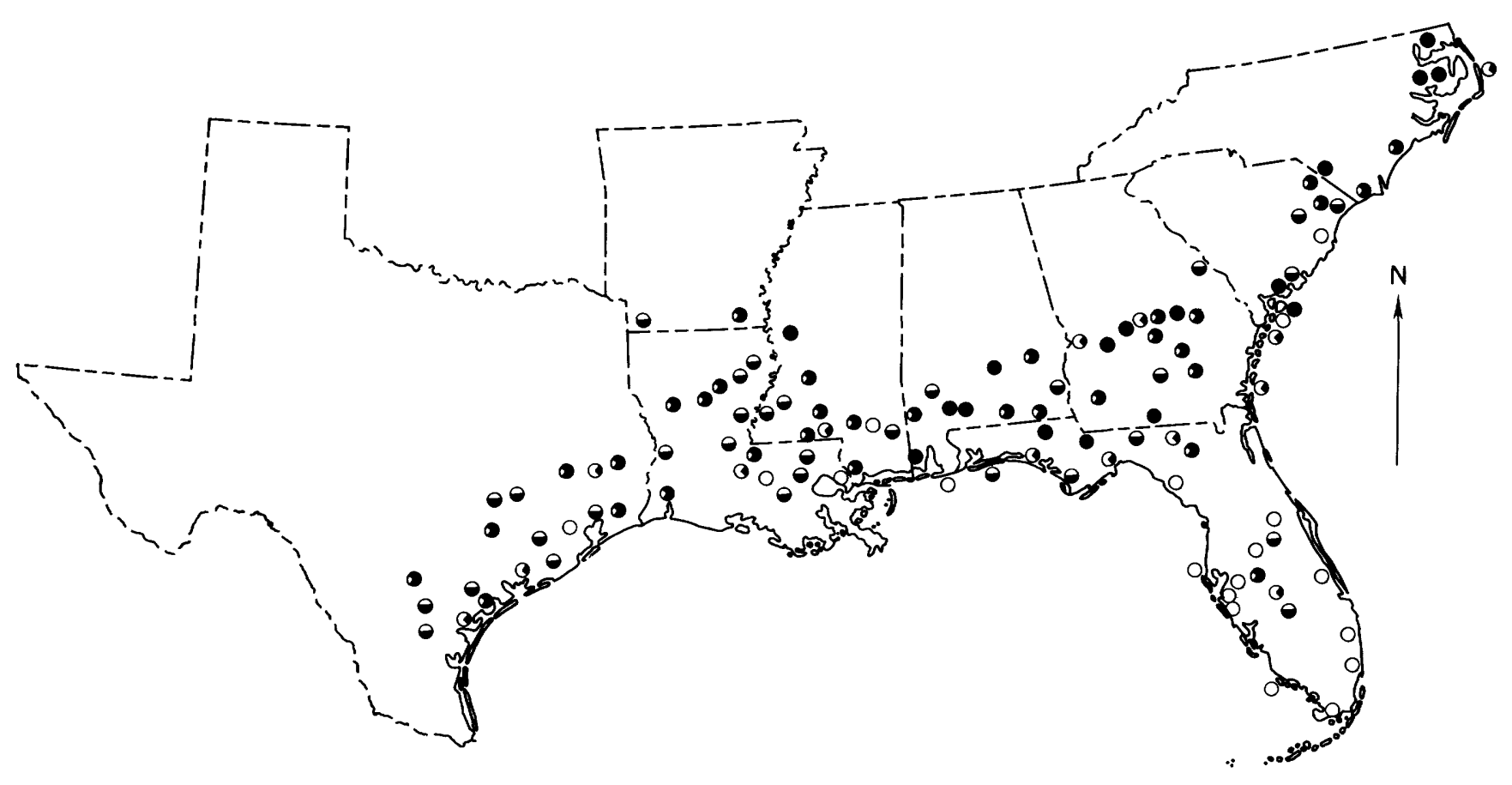

Symbol, and percentage of total samples
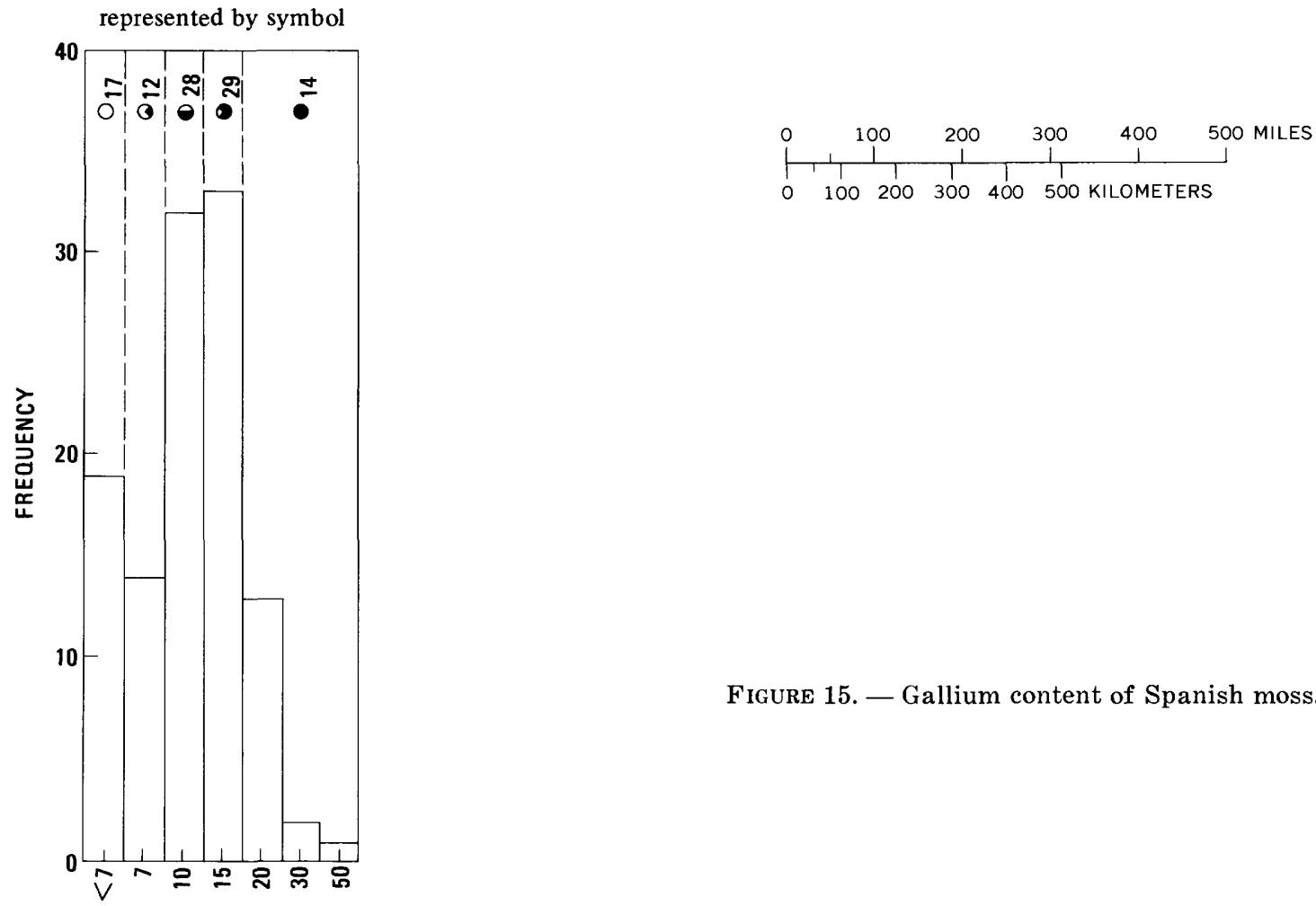

GALLIUM, IN PARTS PER MILLION IN ASH

Geometric mean, 10

Geometric deviation, 1.71

Number of samples and analyses, 114

Figure 15. - Gallium content of Spanish moss. 


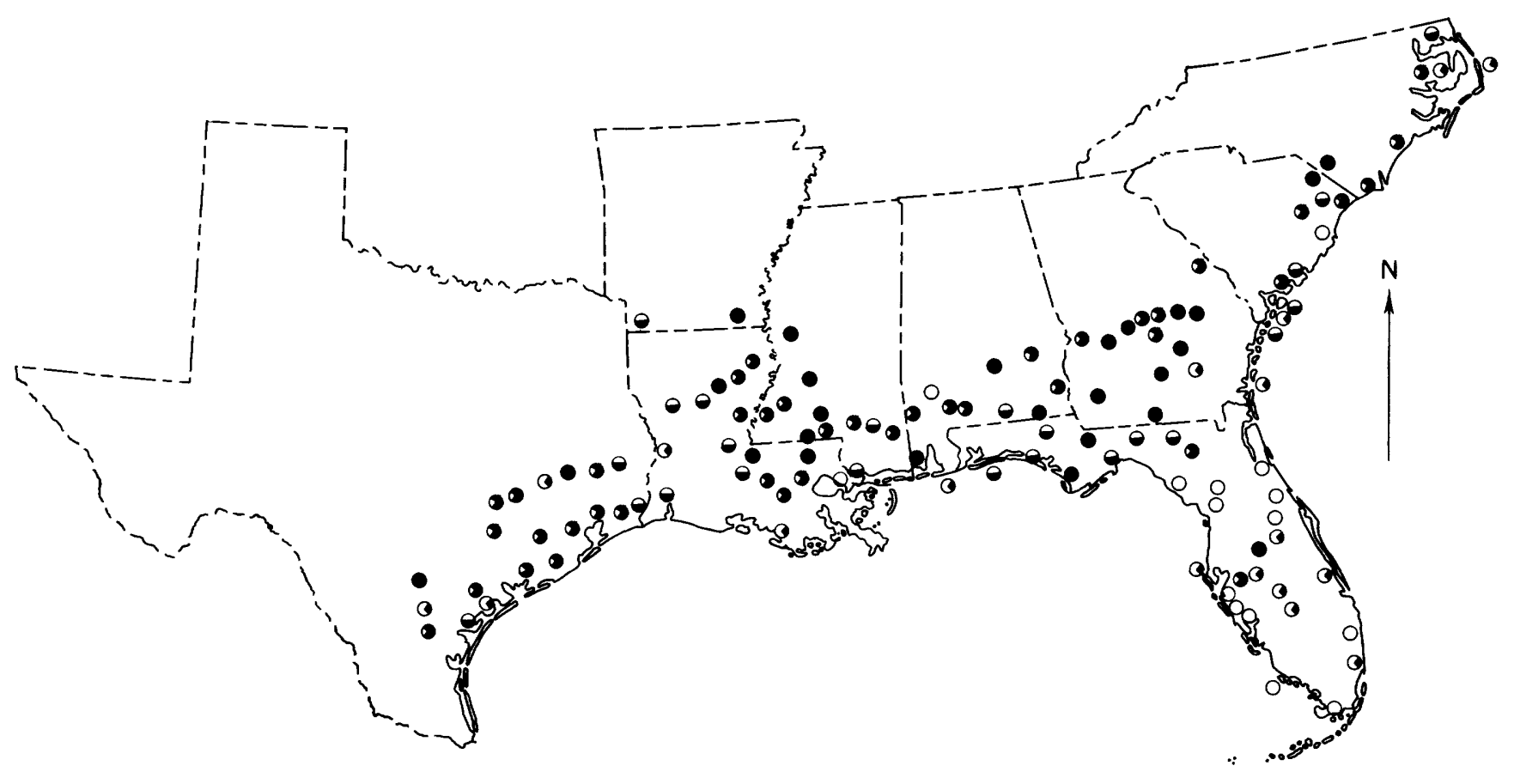

Symbol, and percentage of total samples
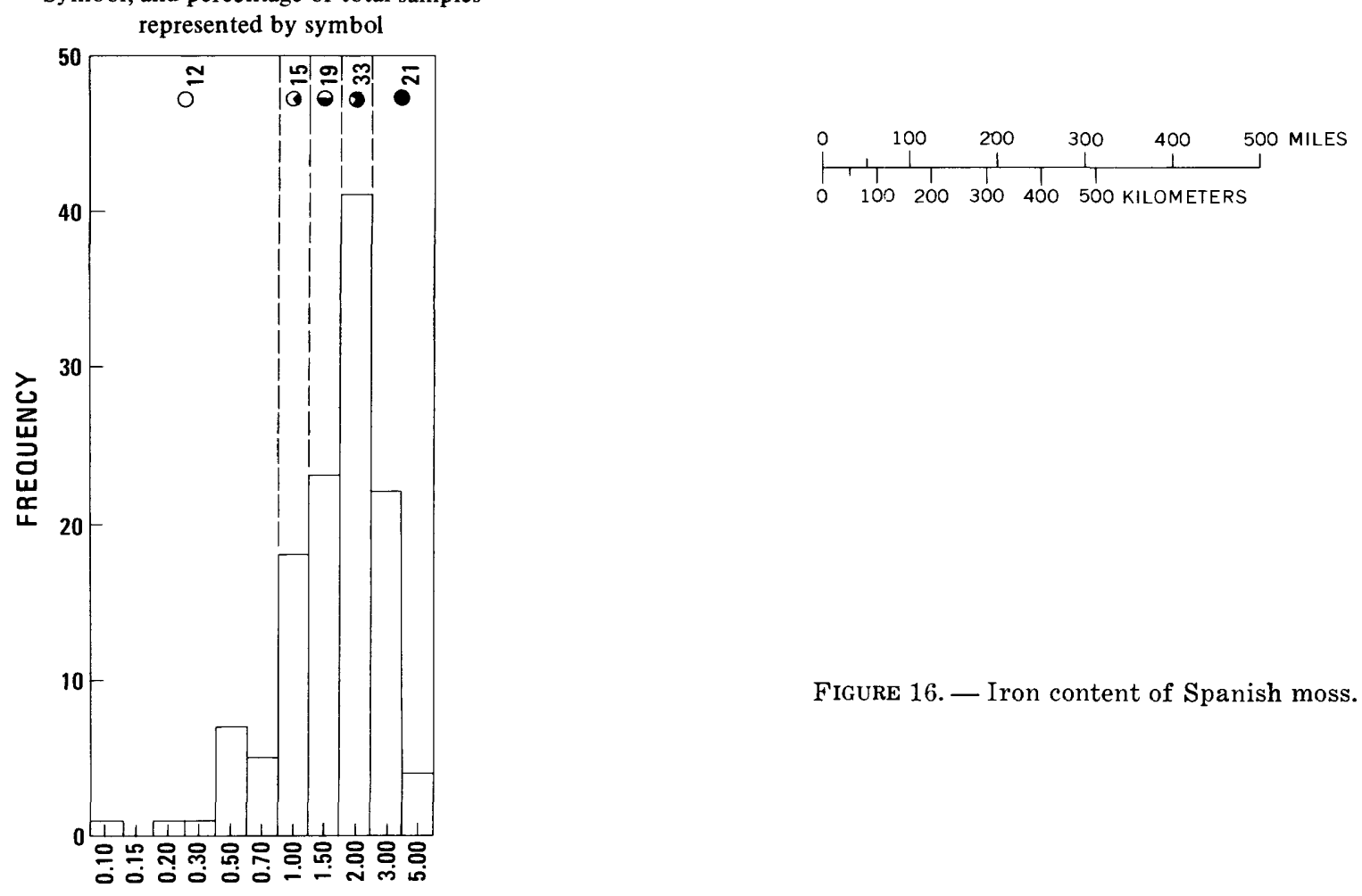

IRON, IN PERCENTAGE IN ASH

Geometric mean, 1.58

Geometric deviation, 1.87

Number of samples and analyses, 123 


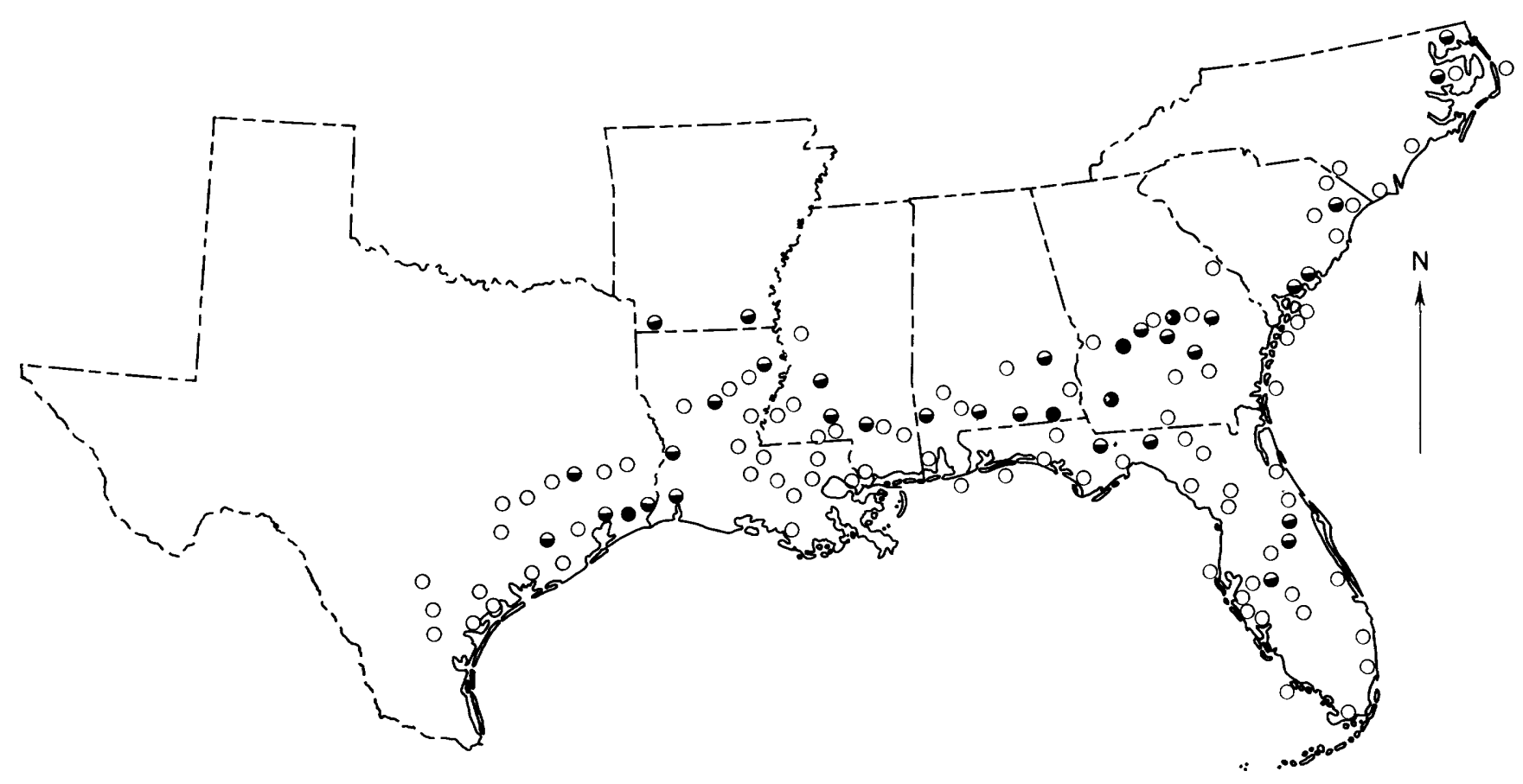

Symbol, and percentage of total samples represented by symbol
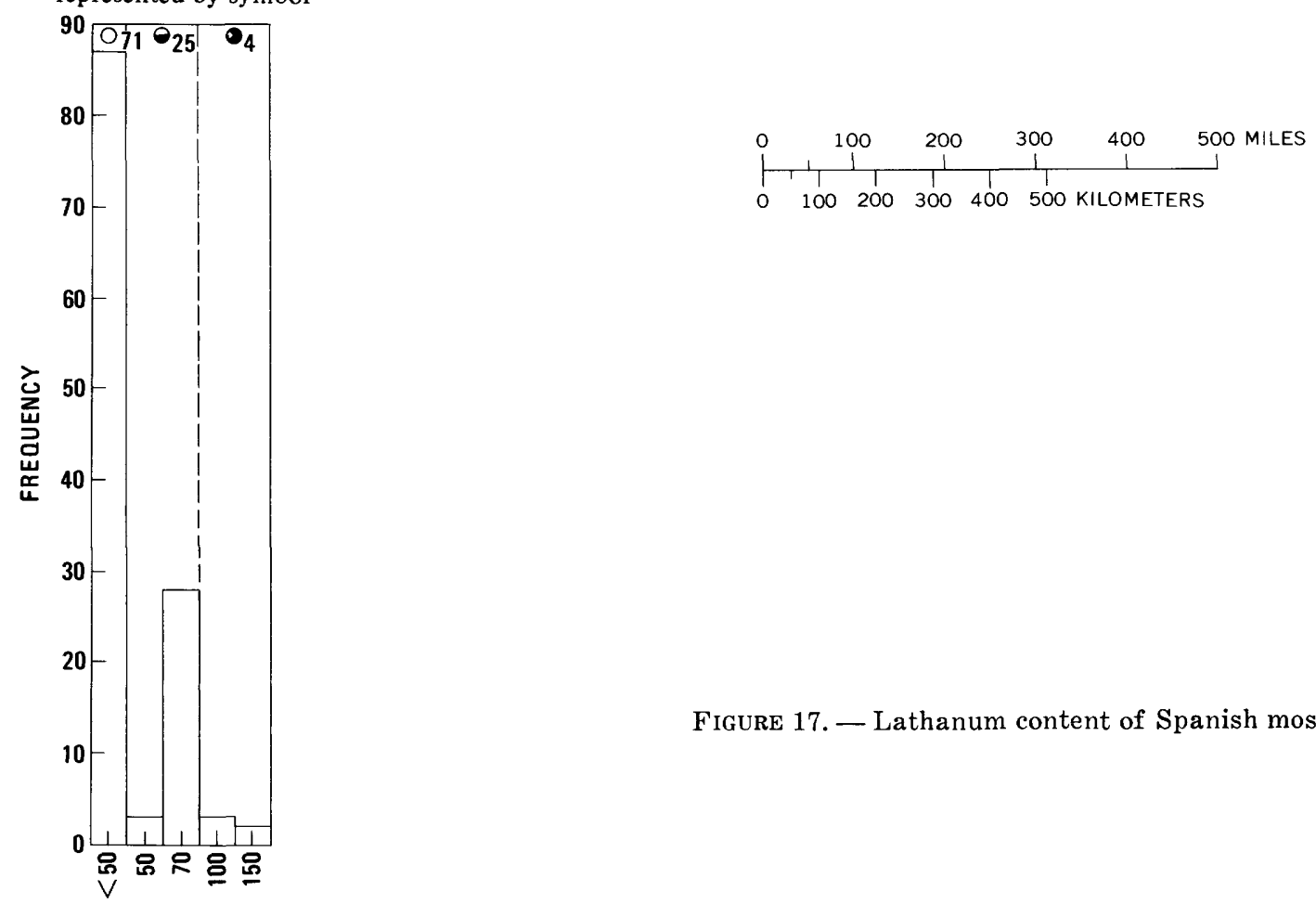

LANTHANUM, IN PARTS PER MILLION IN ASH

Geometric mean, 14

Geometric deviation, 3.80

Number of samples and analyses, 123 

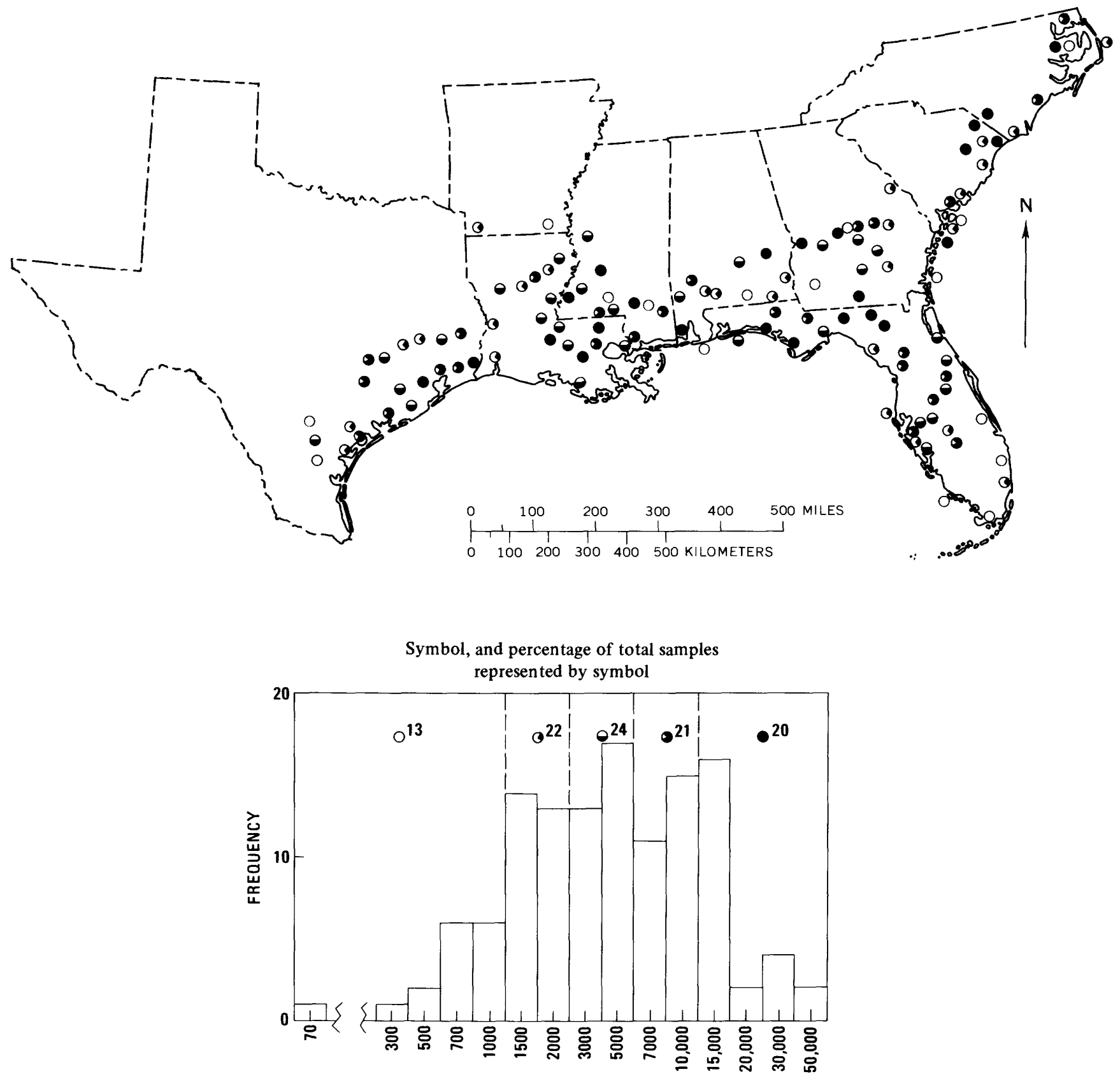

LEAD, IN PARTS PER MILLIDN IN ASH

Geometric mean, 4,170

Geometric deviation, 3.16

Number of samples and analyses, 123

Figure 18. - Lead content of Spanish moss. 


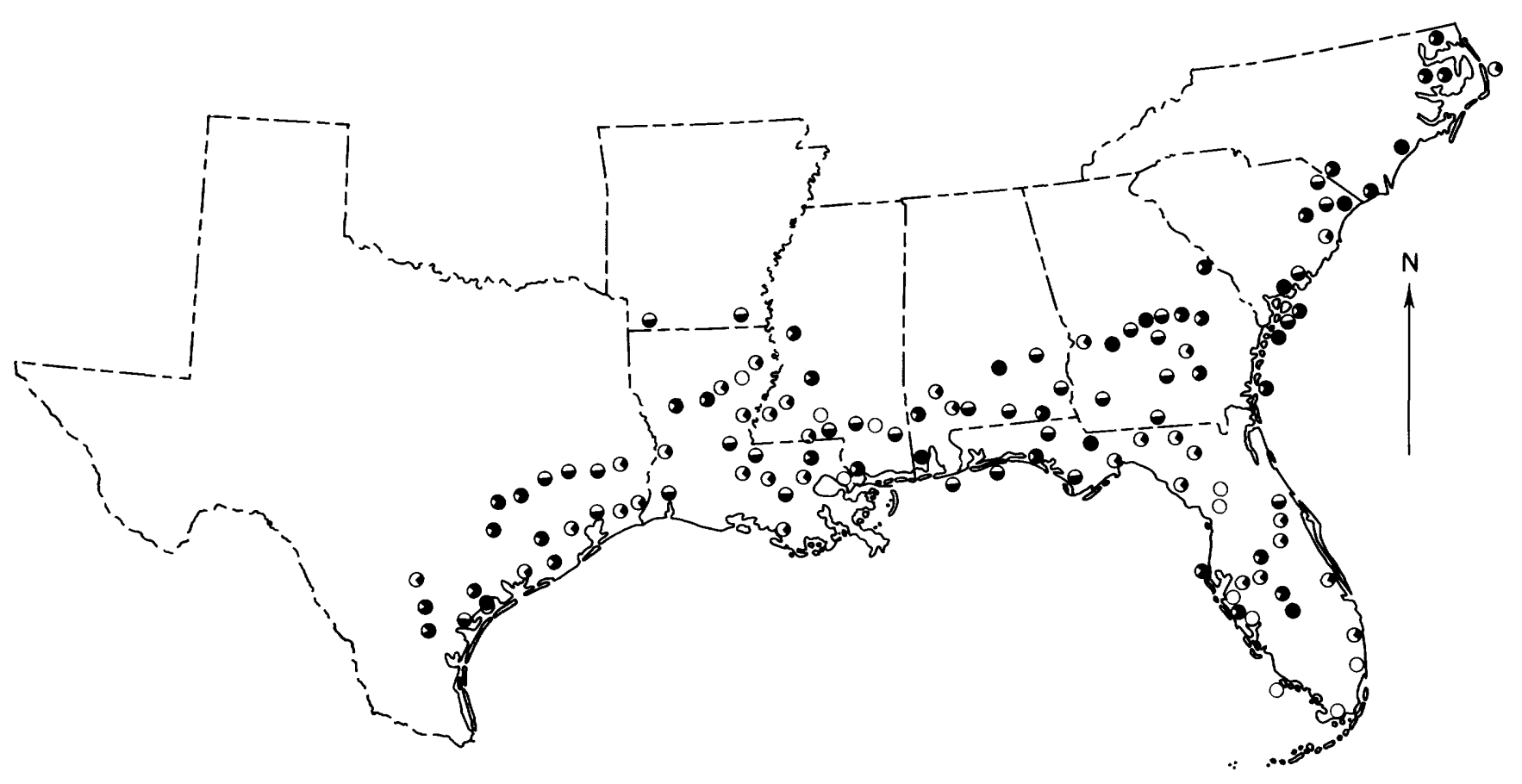

Symbol, and percentage of total samples
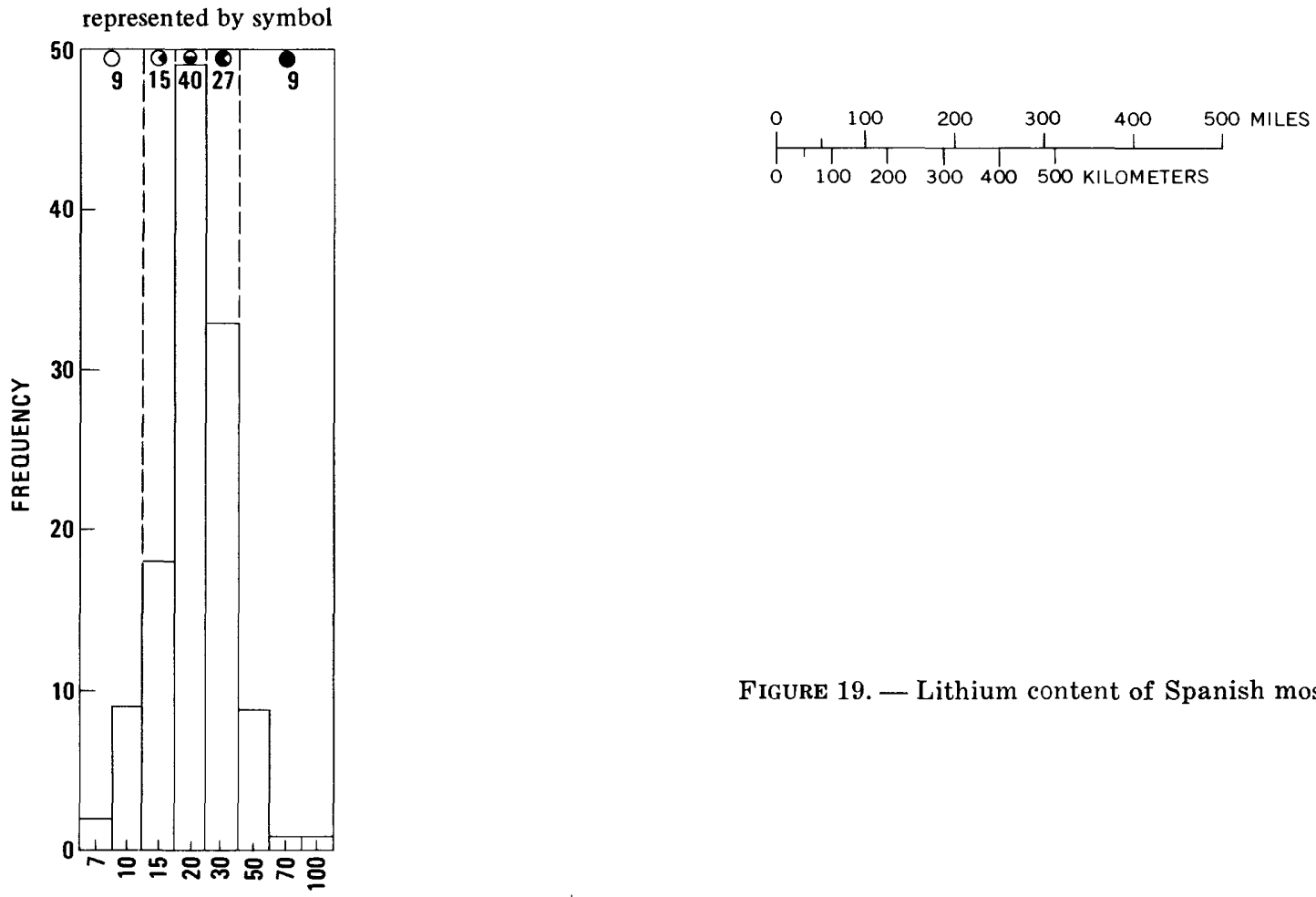

LITHIUM, IN PARTS PER MILLION IN ASH

Geometric mean, 22.4

Geometric deviation, 1.53

Number of samples and analyses, 122

Figure 19. - Lithium content of Spanish moss. 


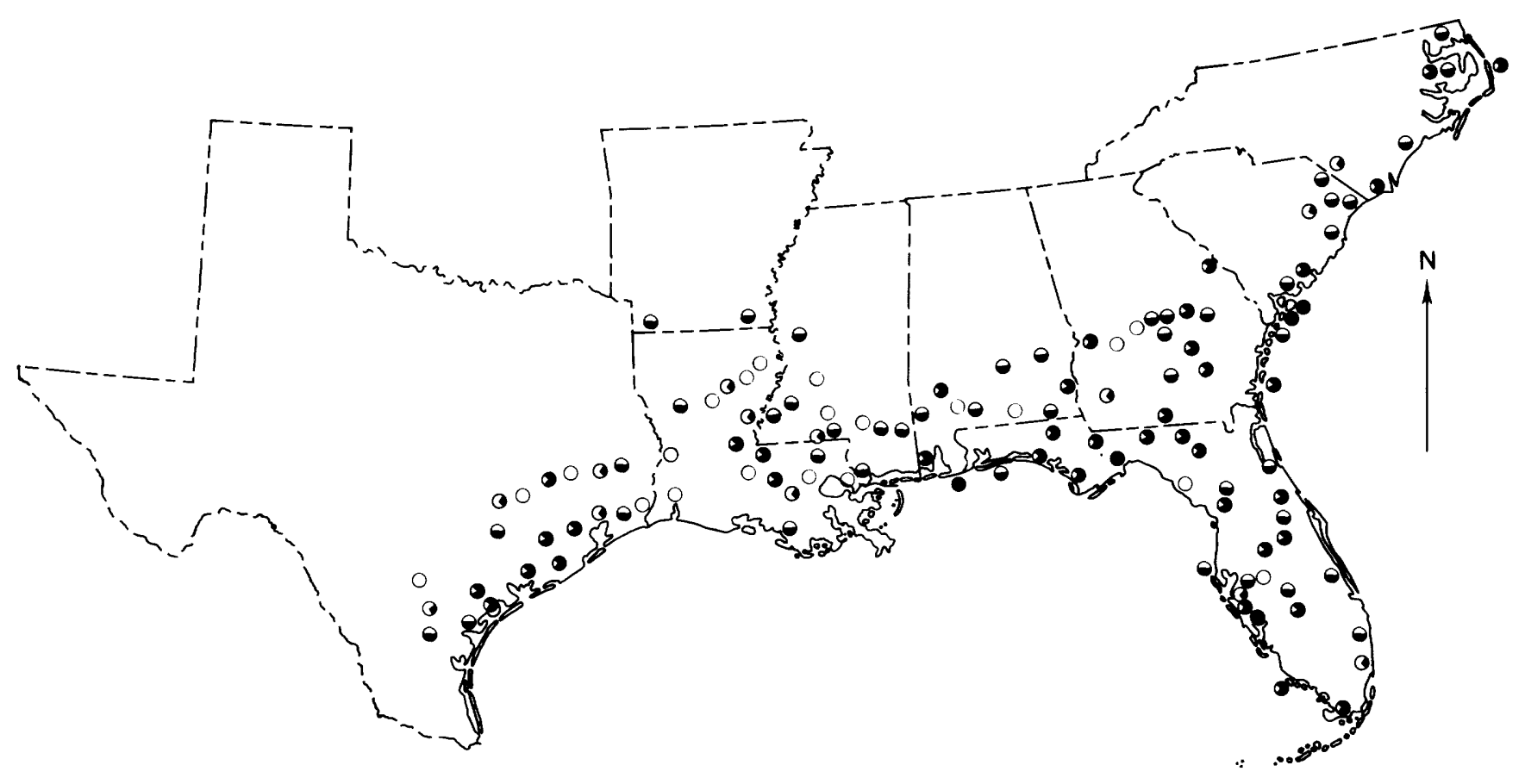

Symbol, and percentage of total samples
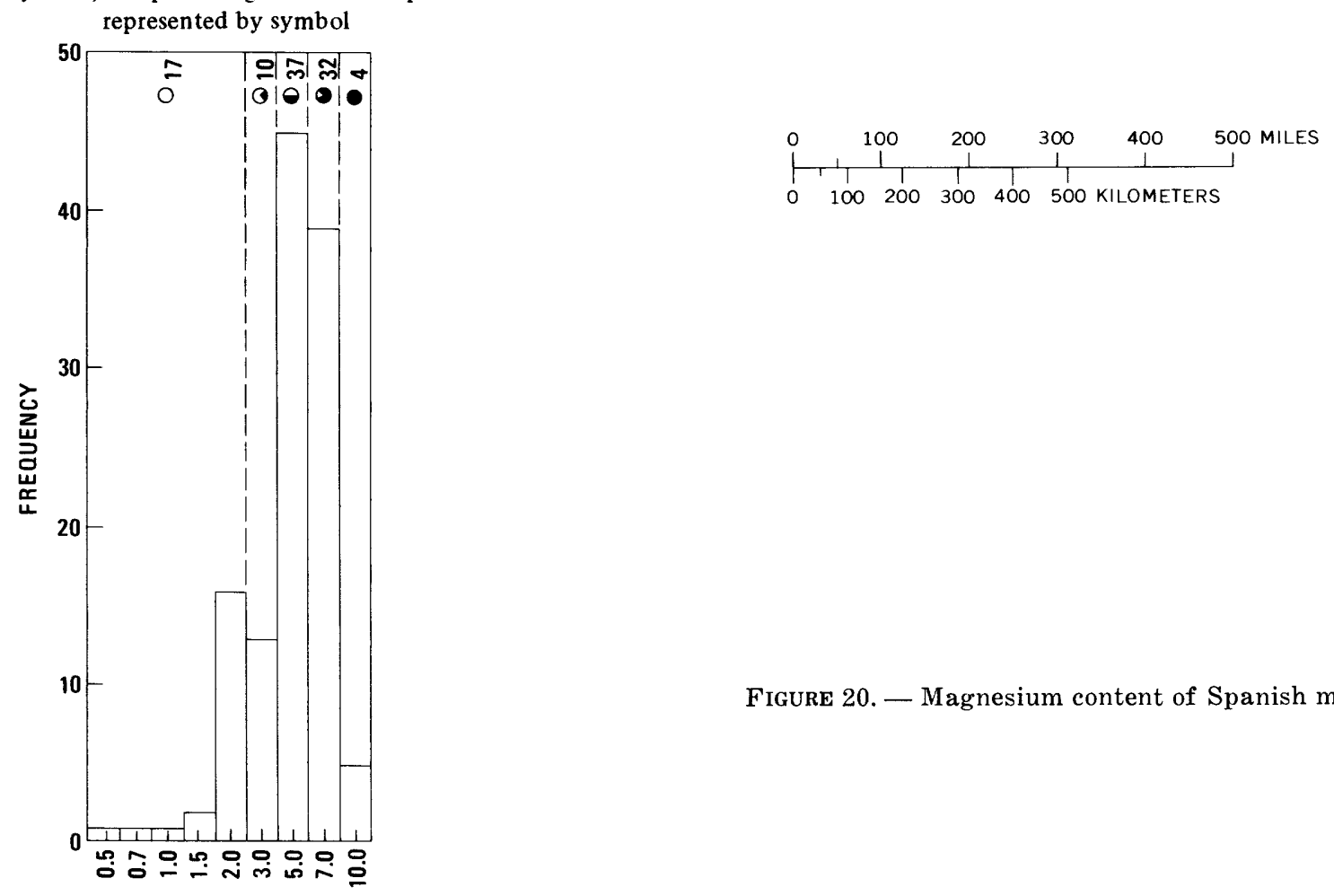

Figure 20. - Magnesium content of Spanish moss.

MAGNESIUM, IN PERCENTAGE IN ASH

Geometric mean, 4.5

Geometric deviation, 1.73

Number of samples and analyses, 123 


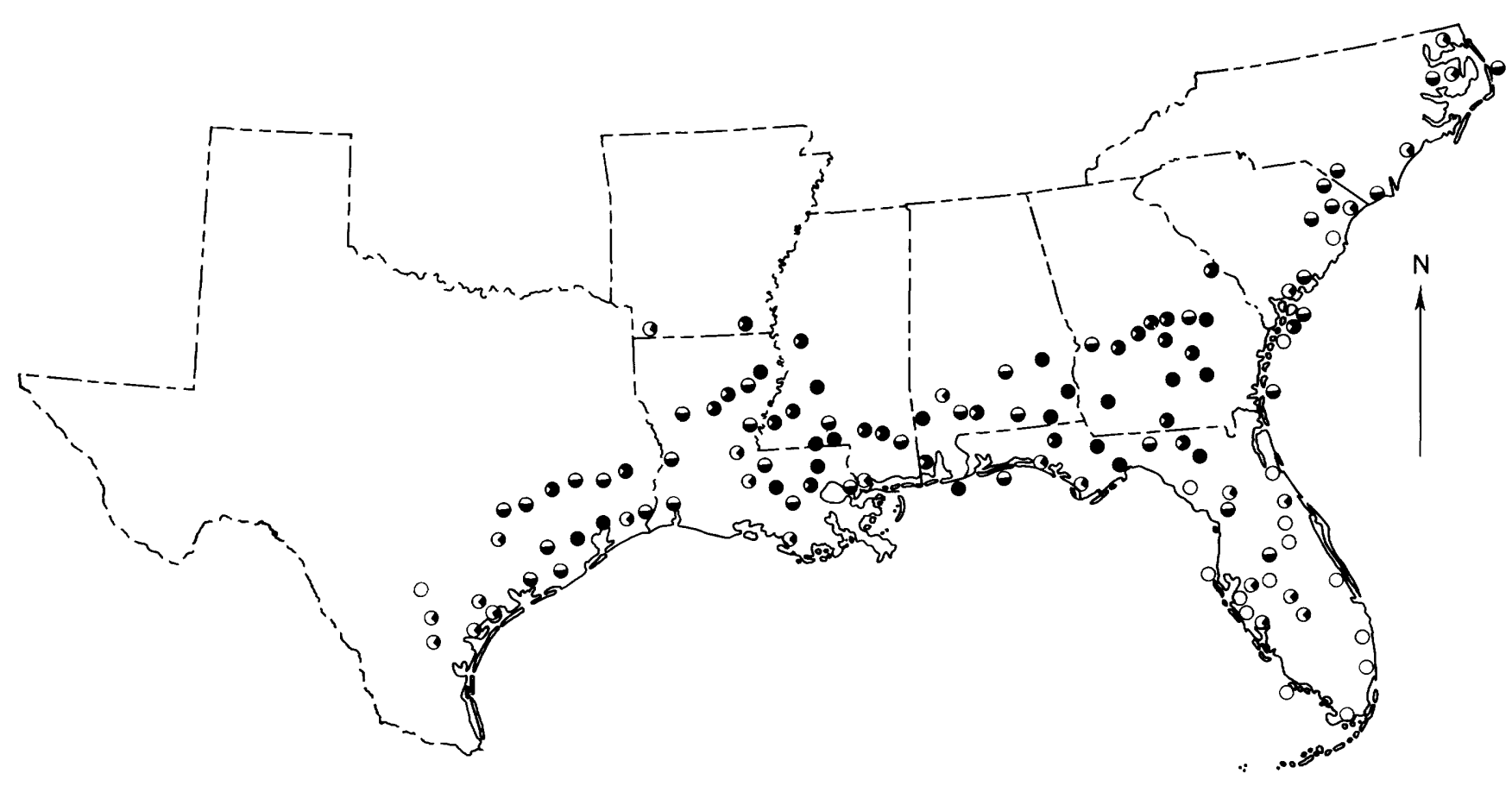

Symbol, and percentage of total samples represented by symbol
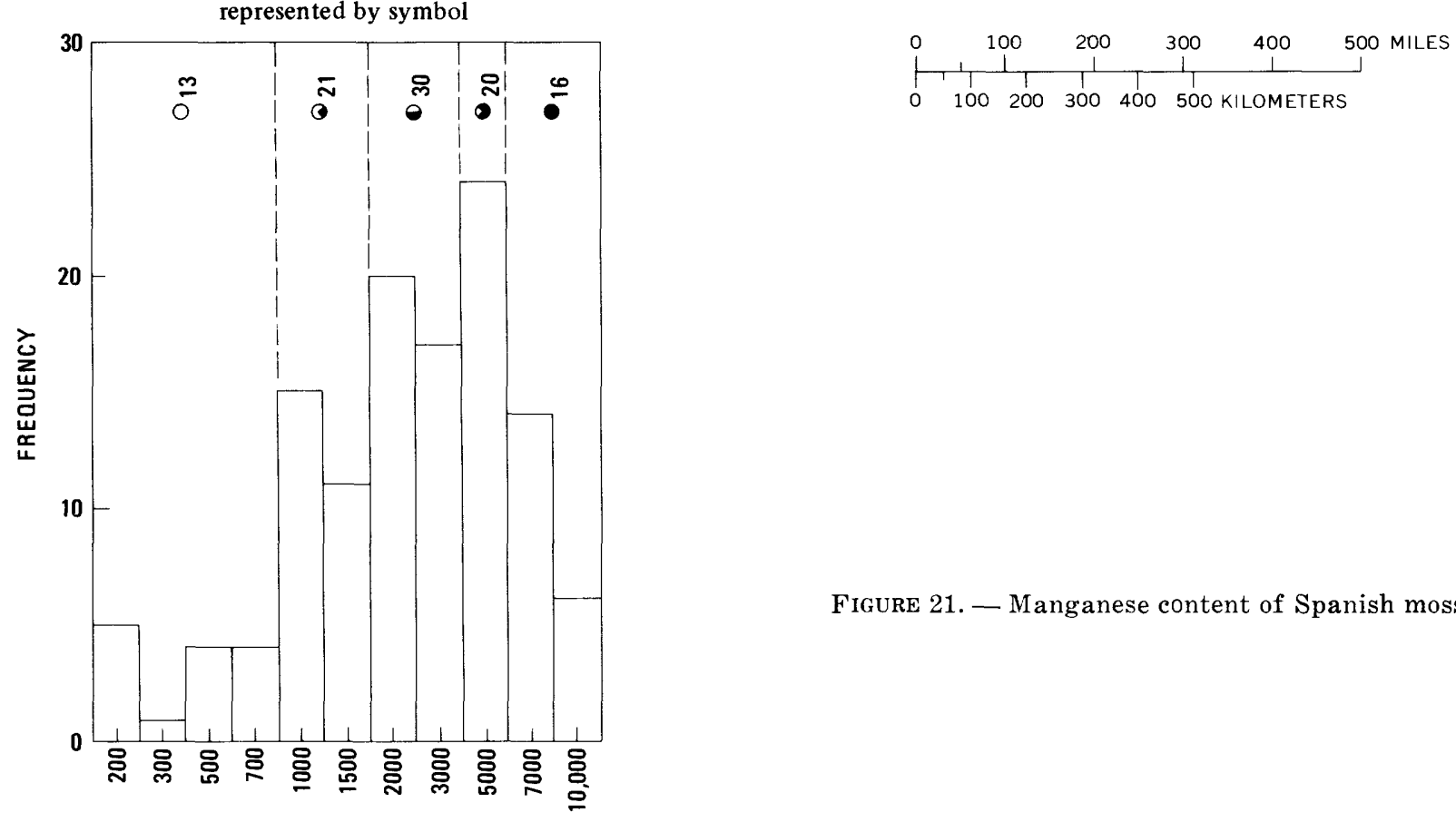

MANGANESE, IN PARTS PER MILLION IN ASH

Geometric mean, 2,300

Geometric deviation, 2.60

Number of samples and analyses, 123 


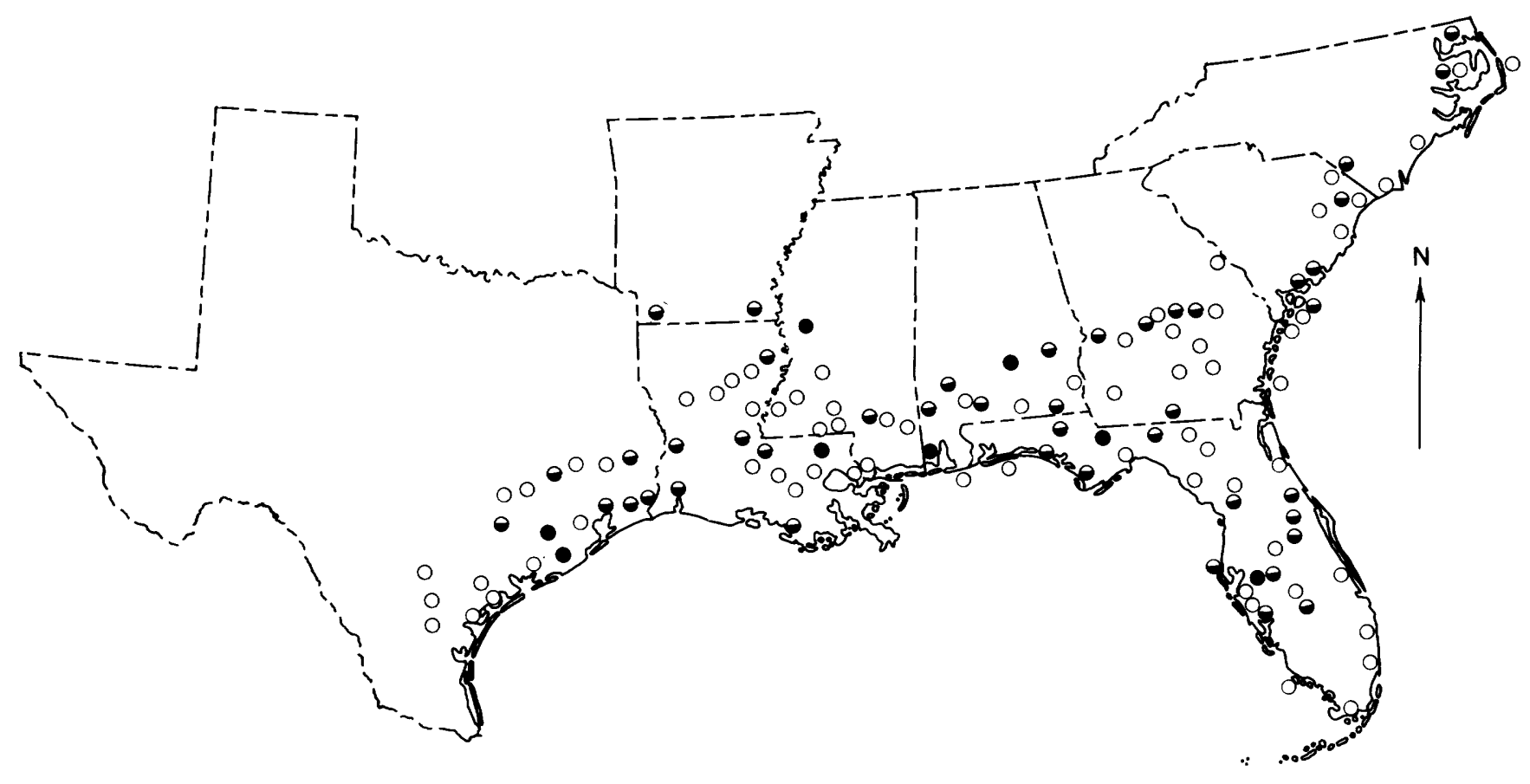

Symbol, and percentage of total samples represented by symbol
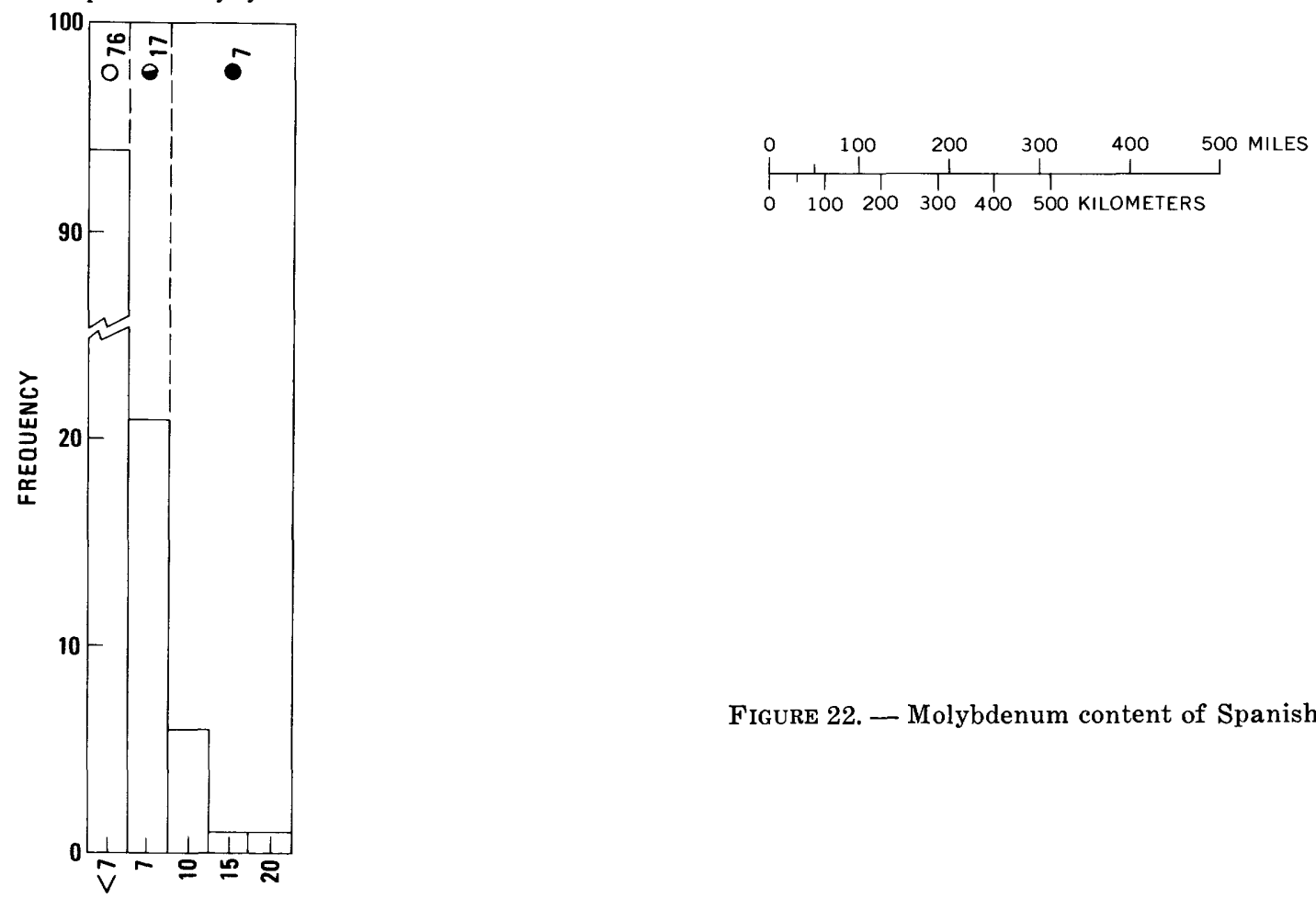

MOLYBDENUM, IN PARTS

PER MILLION IN ASH

Geometric mean, 3.7

Geometric deviation, 1.80

Number of samples and analyses, 123

FIGURE 22. - Molybdenum content of Spanish moss. 

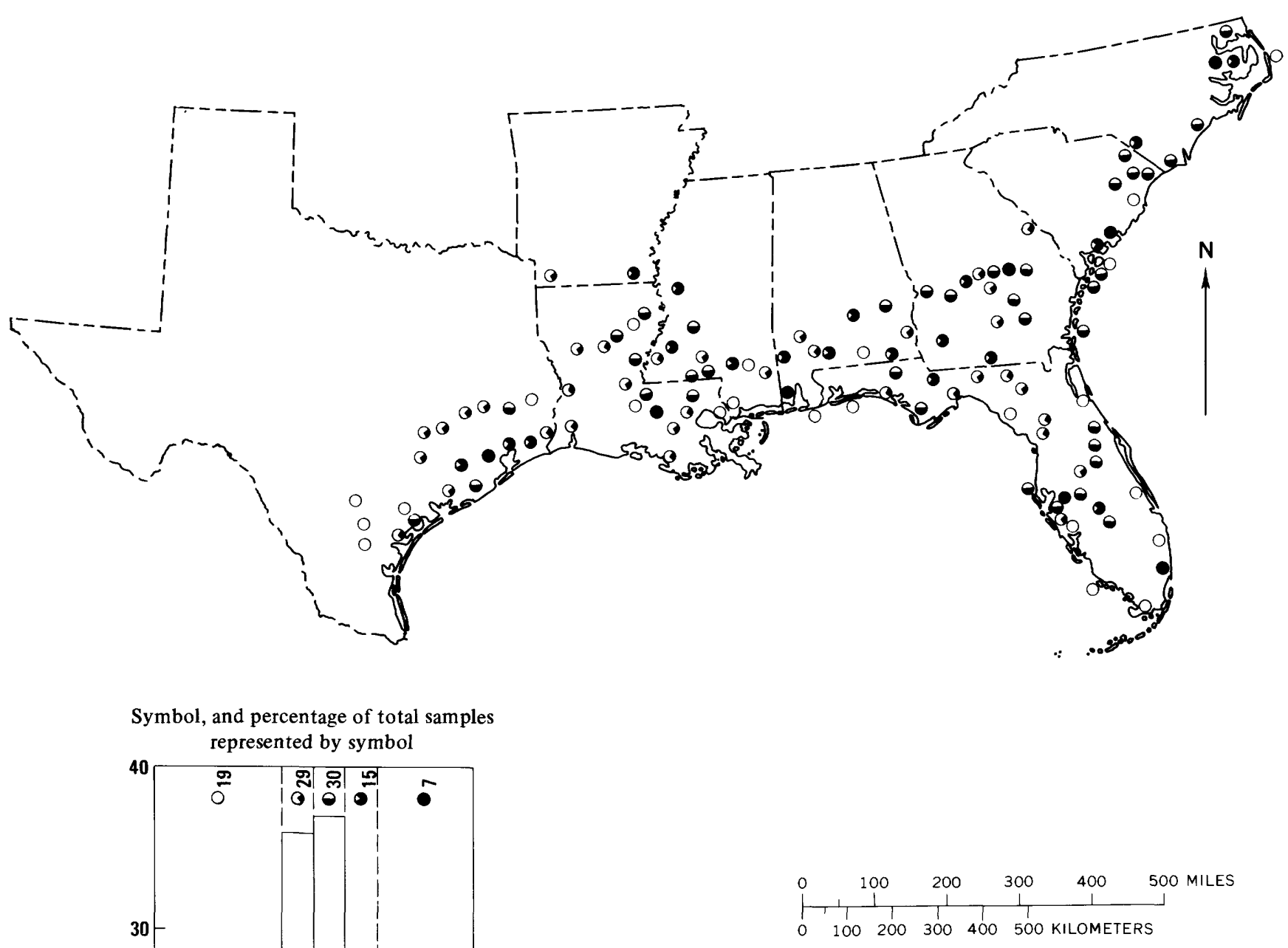

Figure 23. - Nickel content of Spanish moss.

Geometric mean, 39

Geometric deviation, 1.74

Number of samples and analyses, 123 


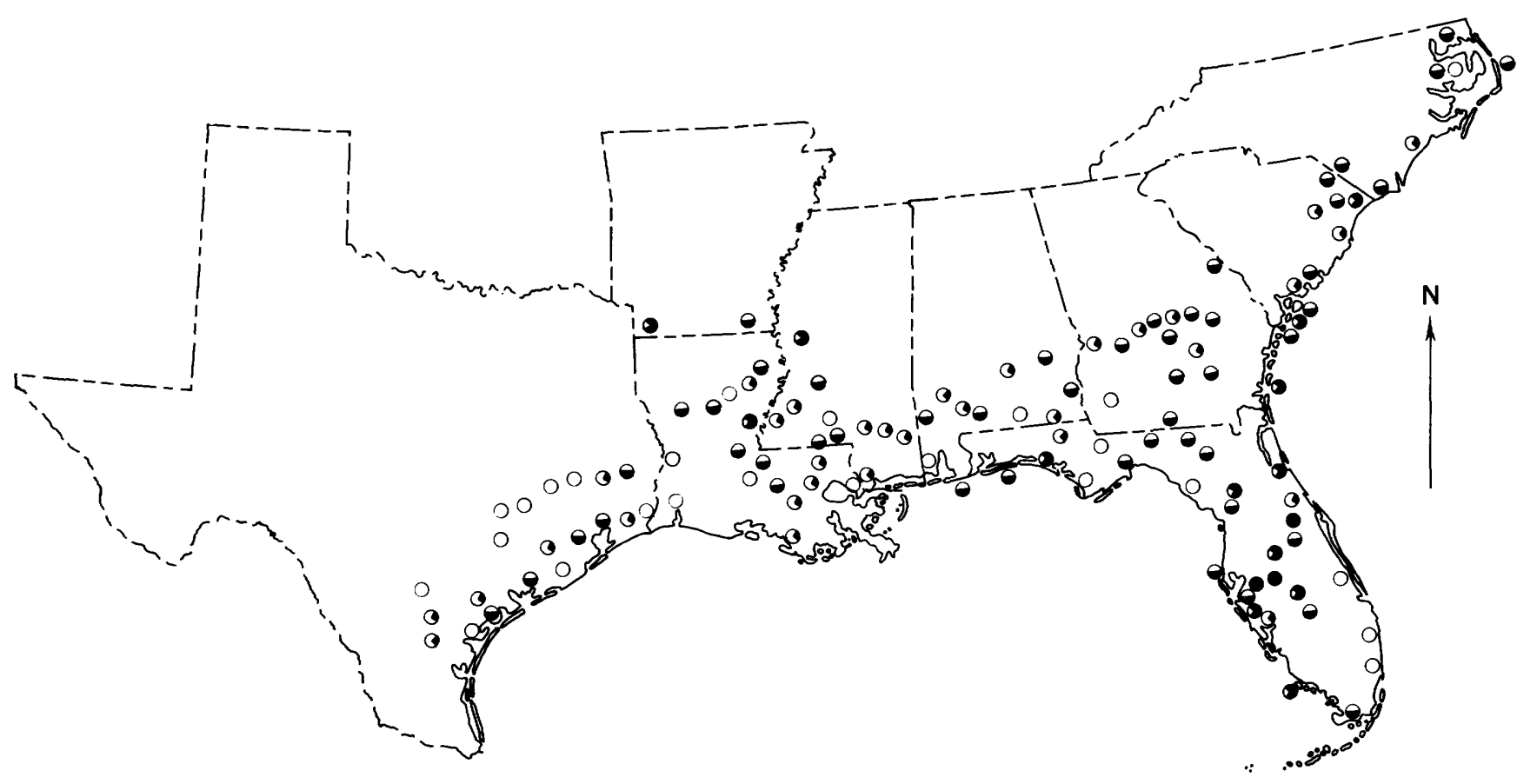

Symbol, and percentage of total samples represented by symbol
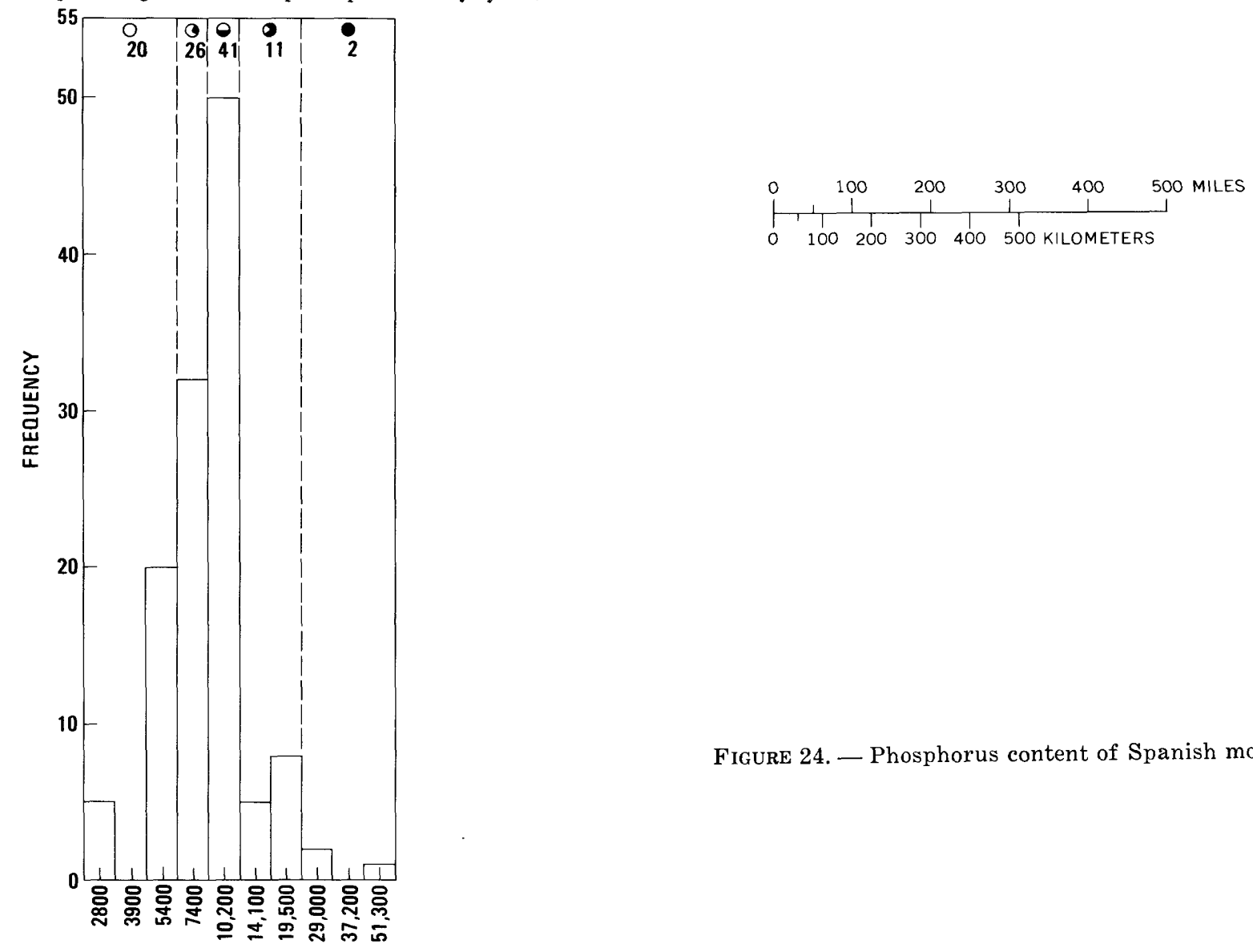

PHOSPHORUS, IN PARTS PER MILLION IN ASH

Geometric mean, 9,371

Geometric deviation, 1.55

Number of samples and analyses, 123 


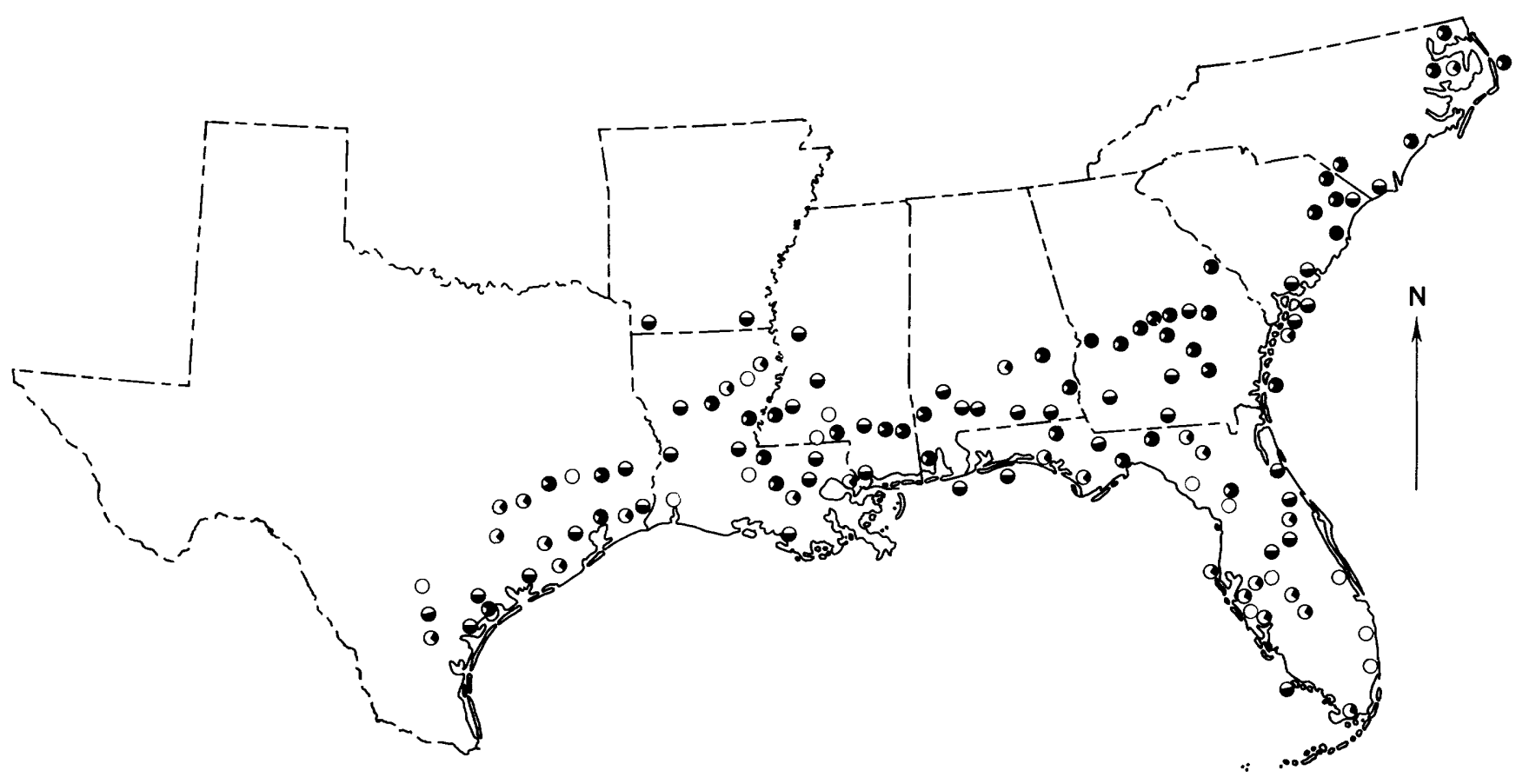

Symbol, and percentage of total samples
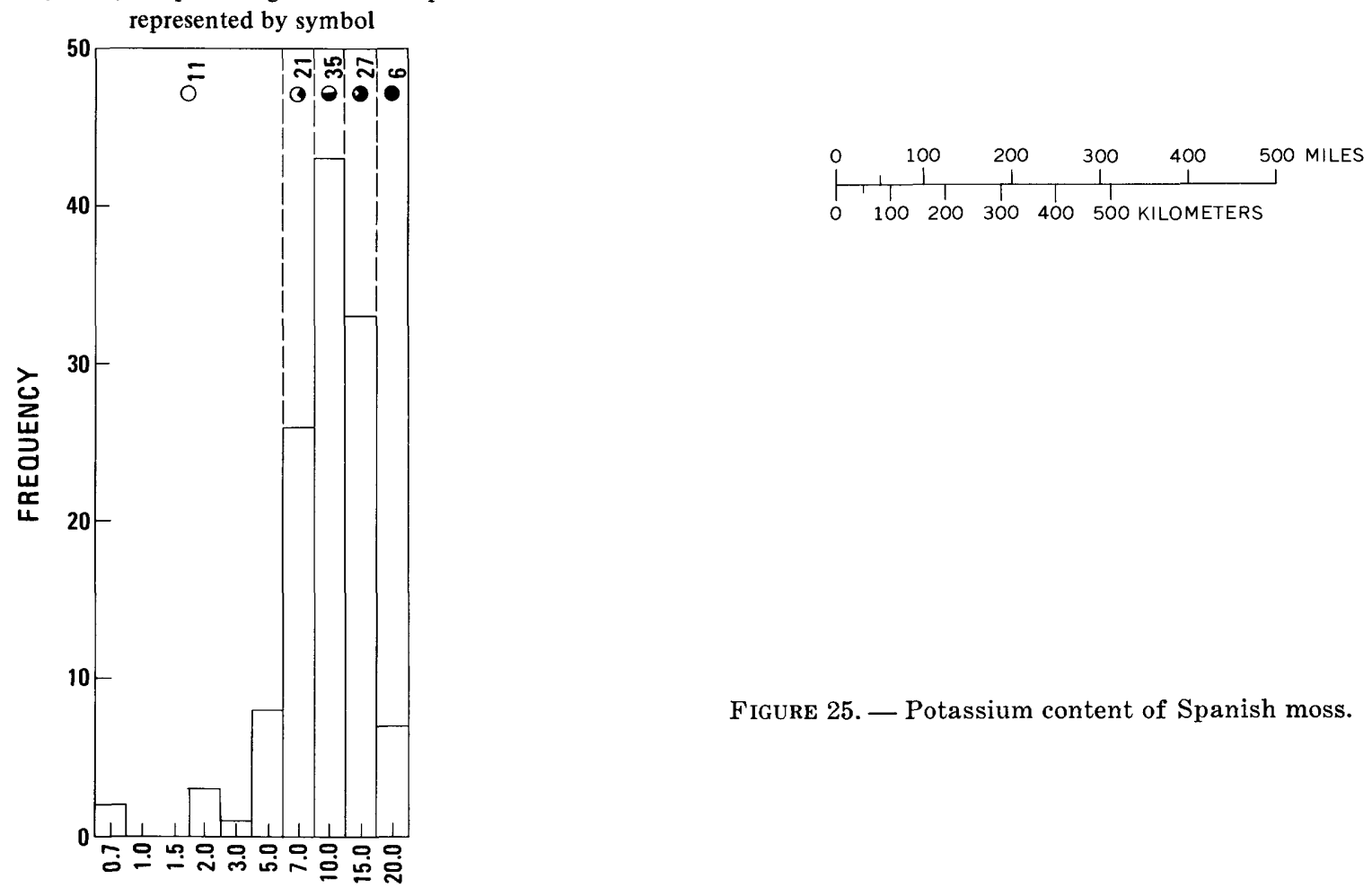

POTASSIUM, IN PERCENTAGE IN ASH

Geometric mean, 9.41

Geometric deviation, 1.74

Number of samples and analyses, 123 


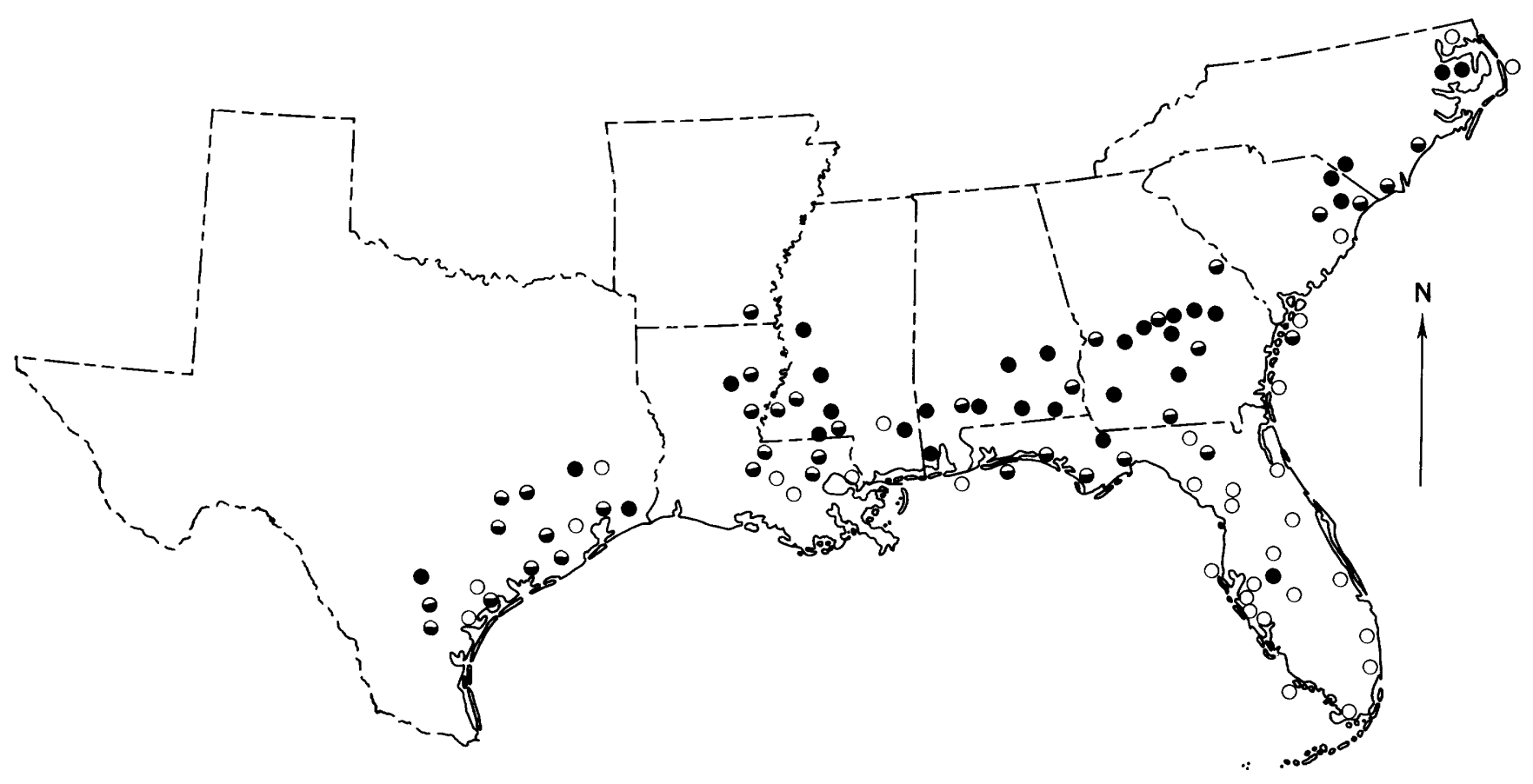

Symbol, and percentage of total samples
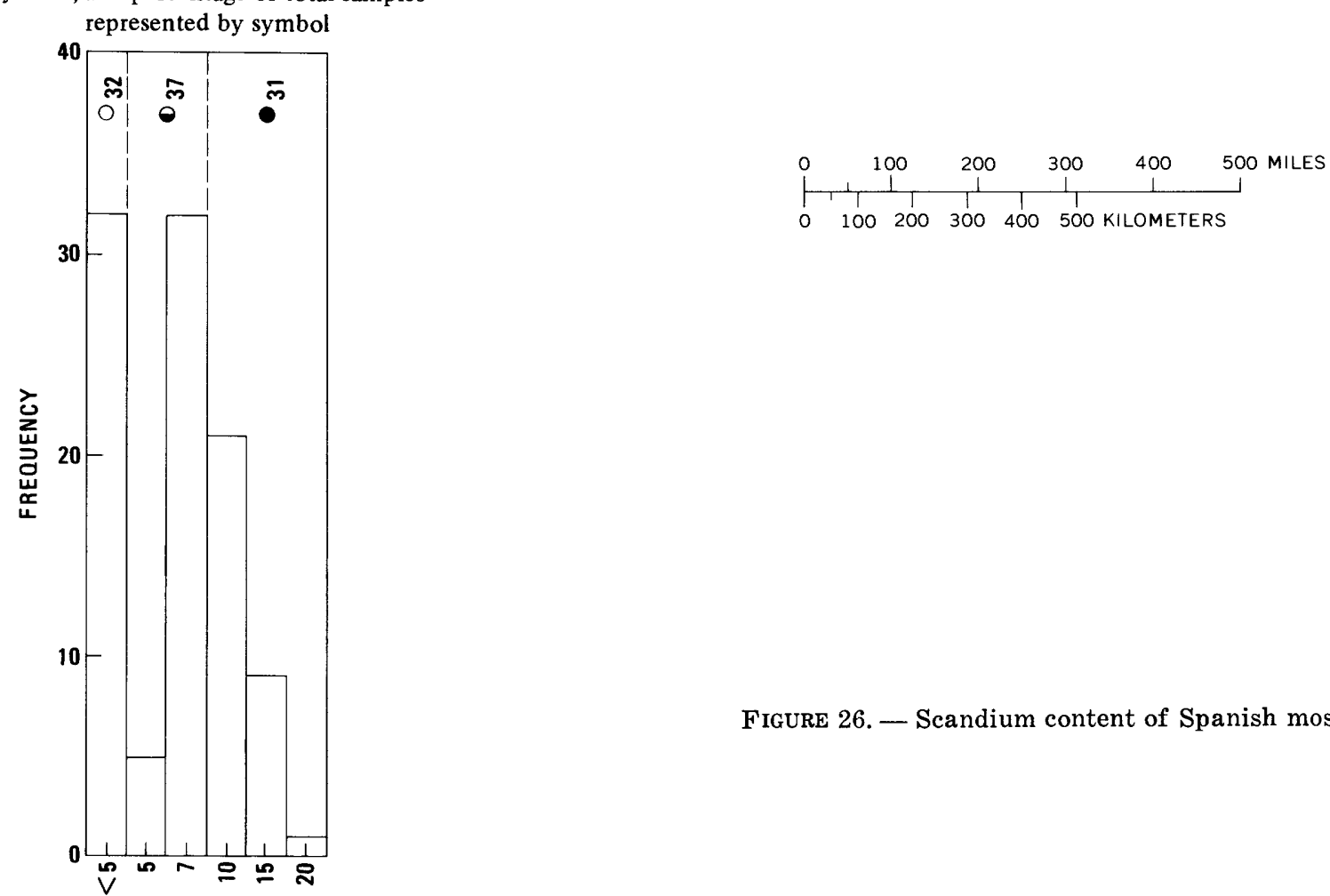

SCANDIUM, IN PARTS PER MILLION IN ASH

Geometric mean, 5.85

Geometric deviation, 1.89

Number of samples and analyses, 100

FIGURE 26. - Scandium content of Spanish moss. 


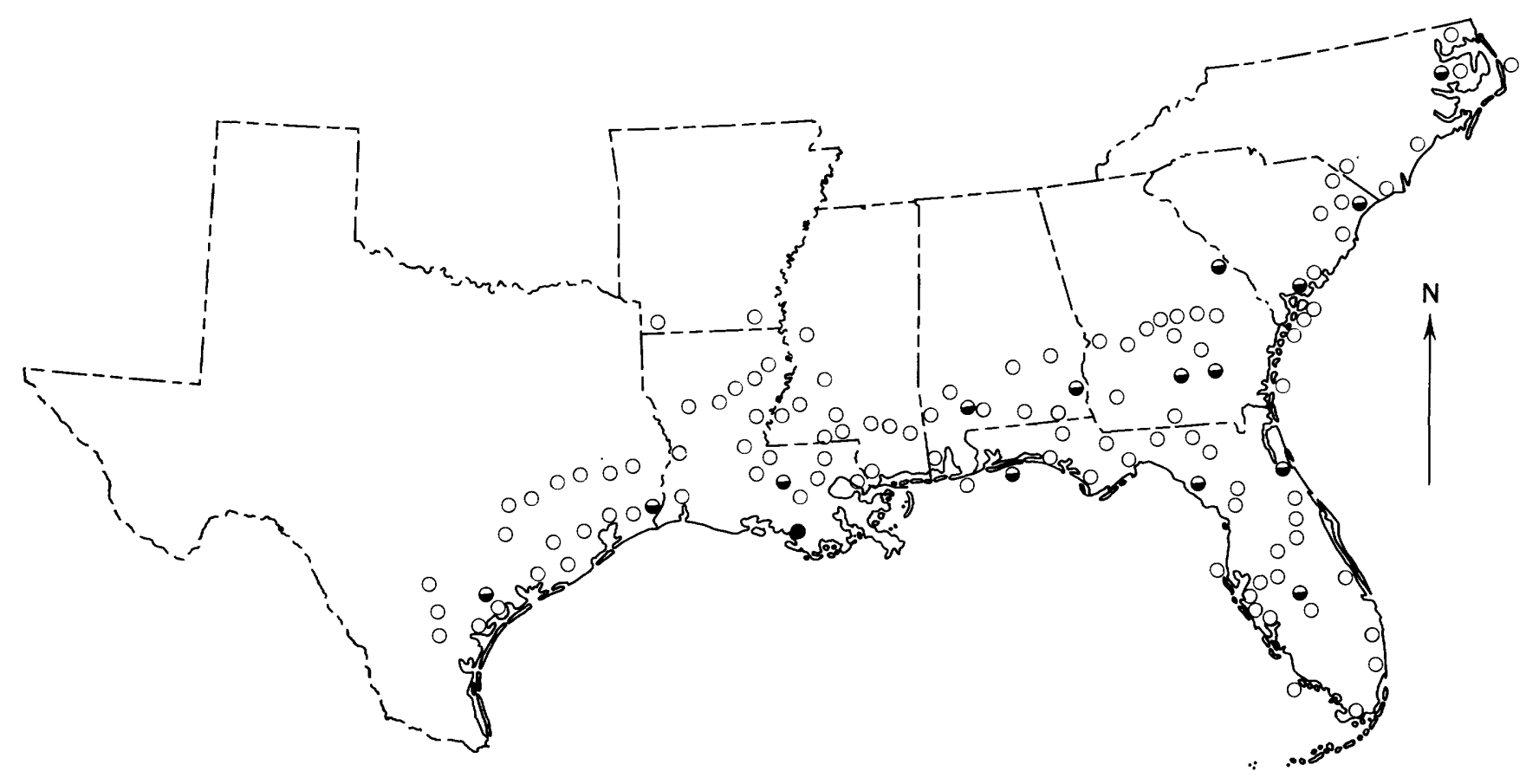

Symbol, and percentage of total samples represented by symbol
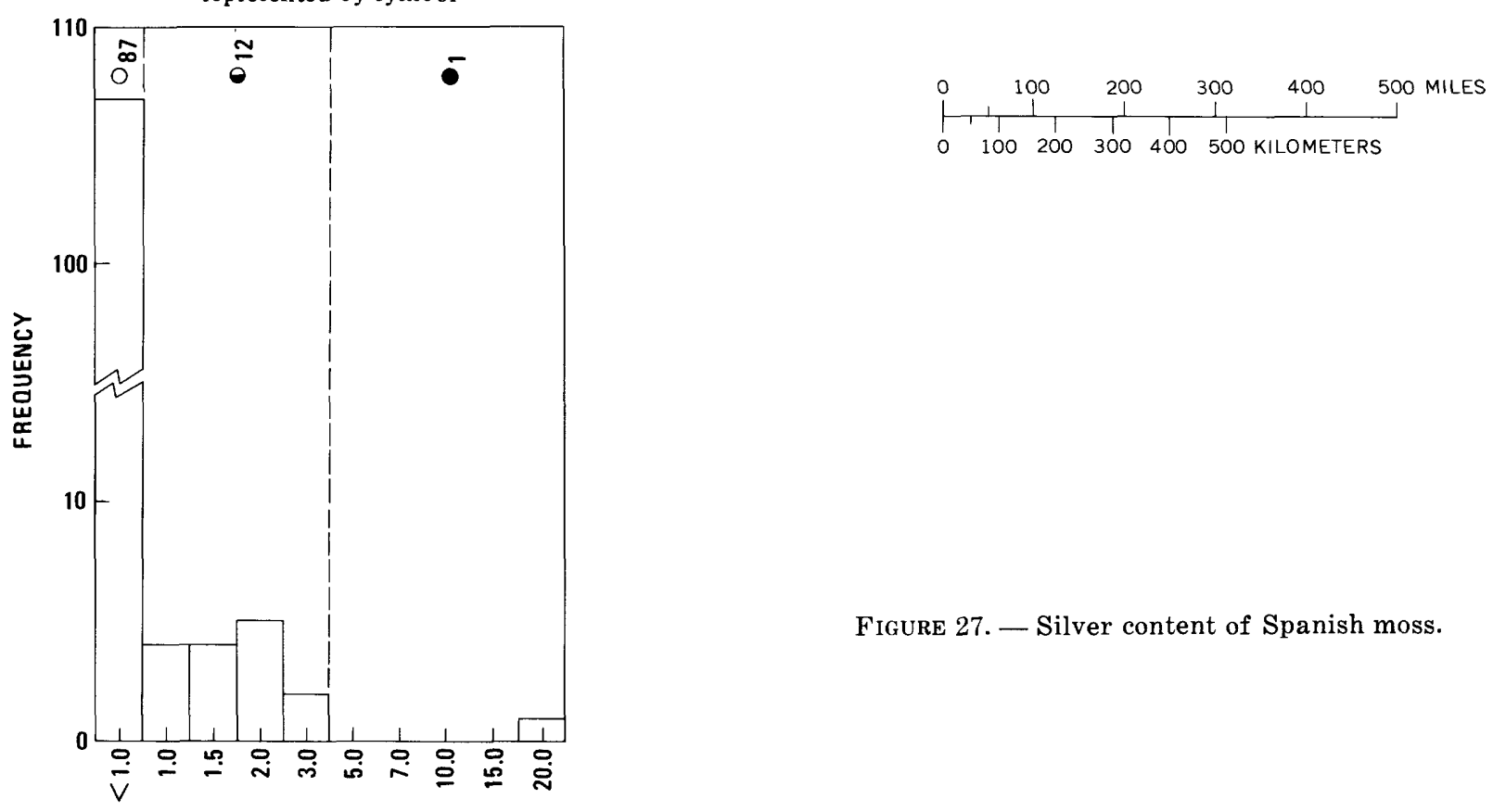

SILVER, IN PARTS PER MILLION IN ASH

Geometric mean, 0.12

Geometric deviation, $\mathbf{5 . 4 2}$

Number of samples and analyses, 123

Figure 27. - Silver content of Spanish moss. 

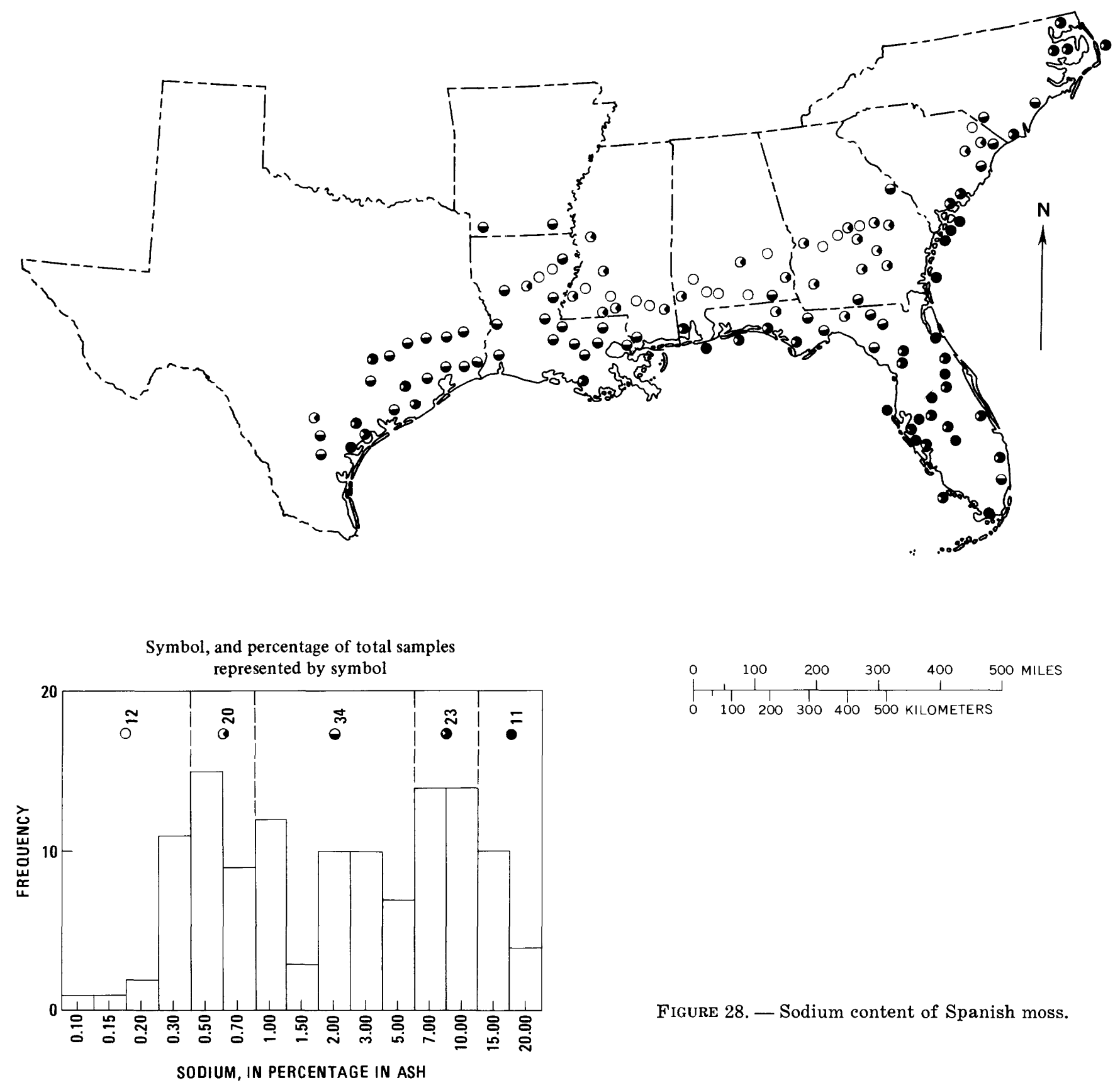

Geometric mean, 2.2

Geometric deviation, 4.05

Number of samples and analyses, 123 


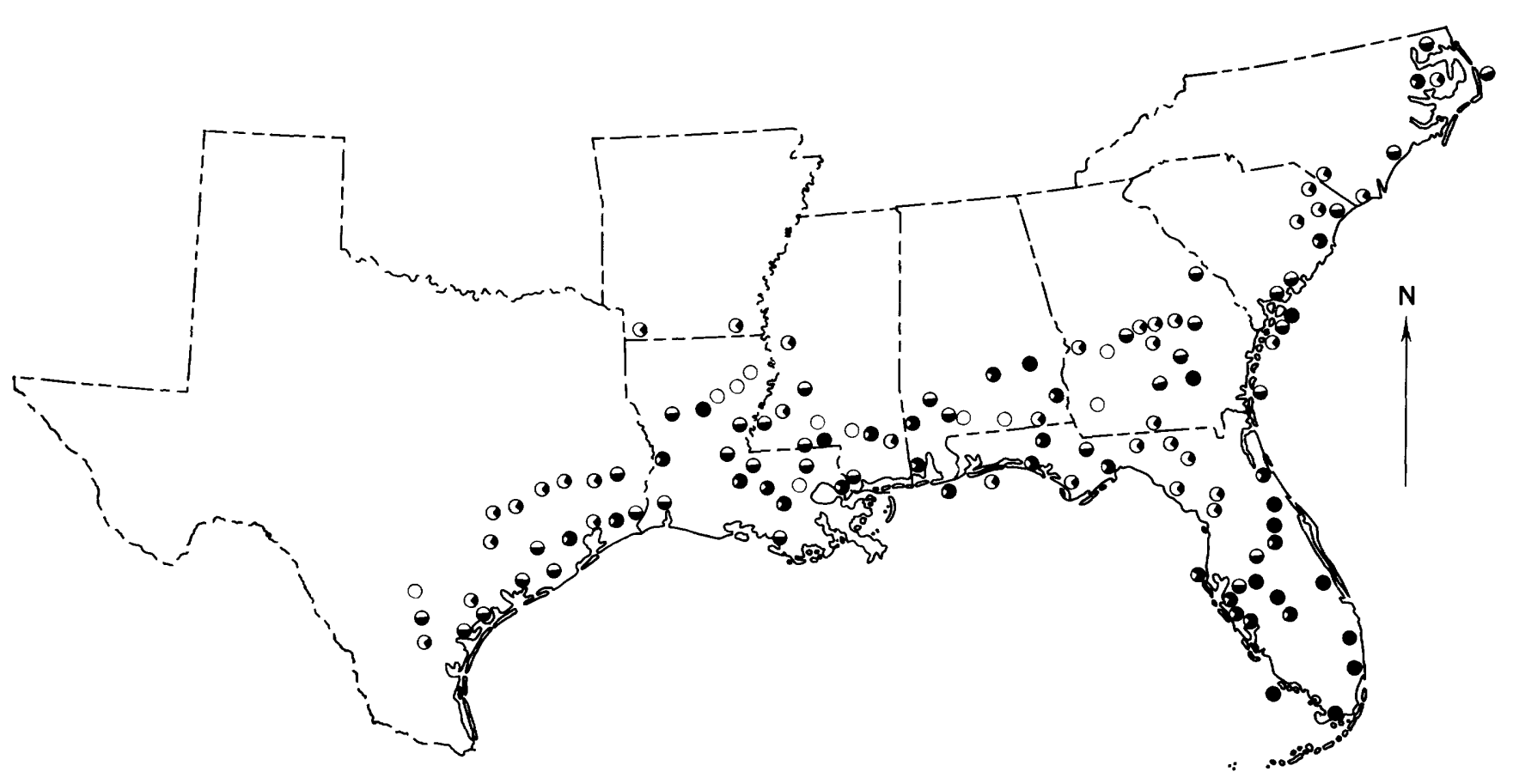

Symbol, and percentage of total samples represented by symbol
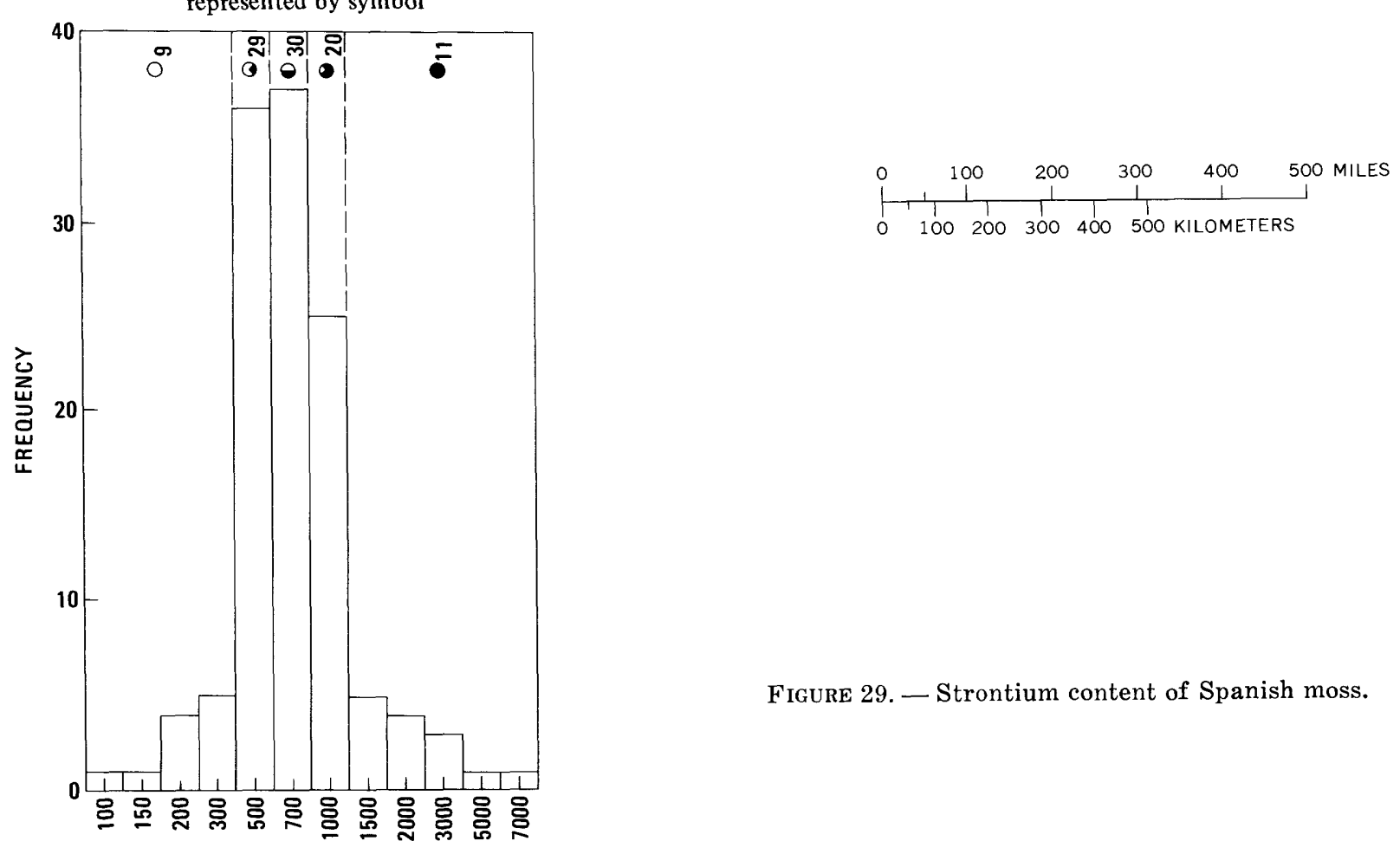

STRONTIUM, IN PARTS PER MILLION IN ASH

Figure 29. - Strontium content of Spanish moss.

Geometric mean, 704

Geometric deviation, 1.85

Number of samples and analyses, 123 

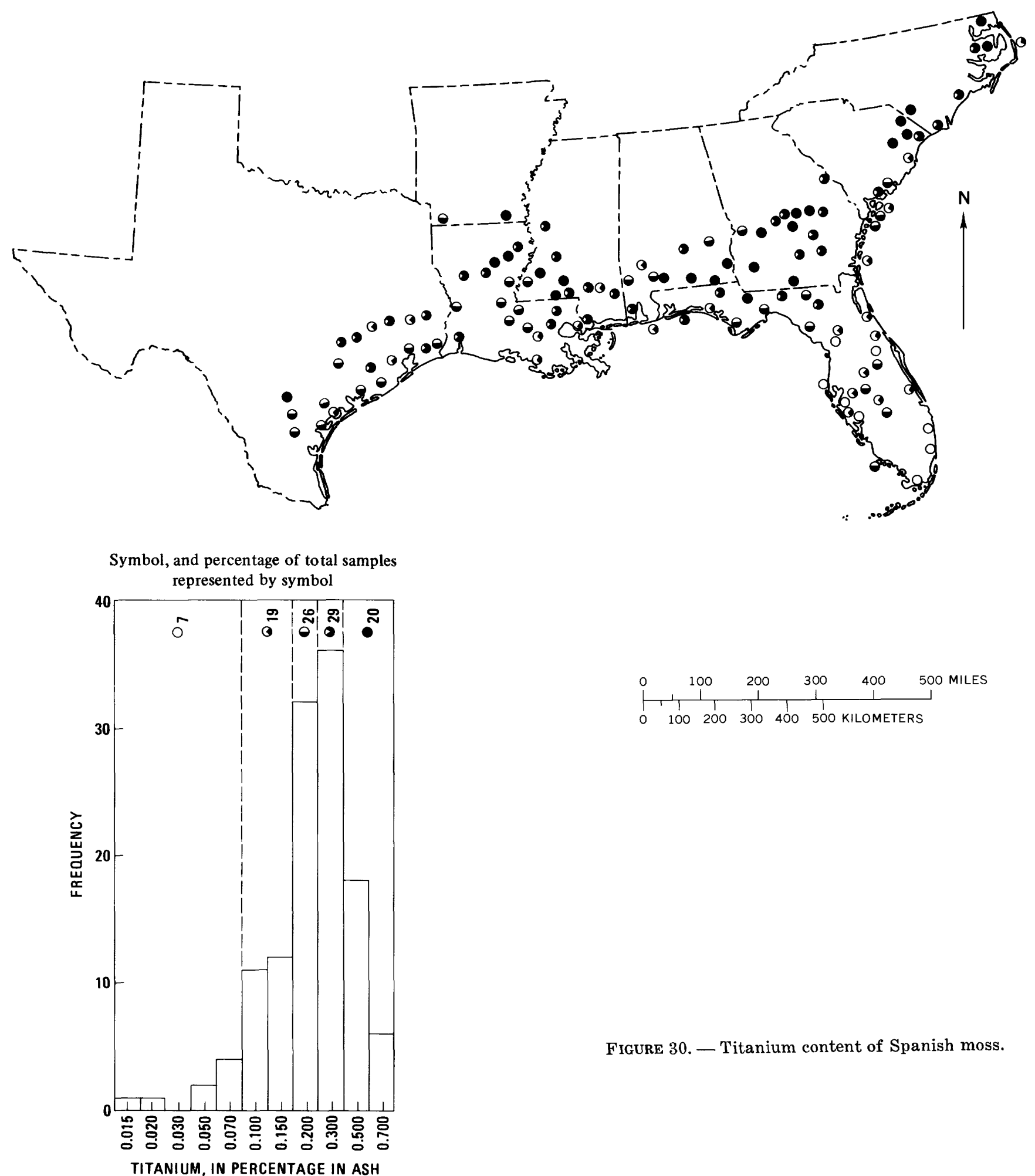

Figure 30. - Titanium content of Spanish moss.

Geometric mean, 0.23

Geometric deviation, 1.96

Number of samples and analyses, 123 


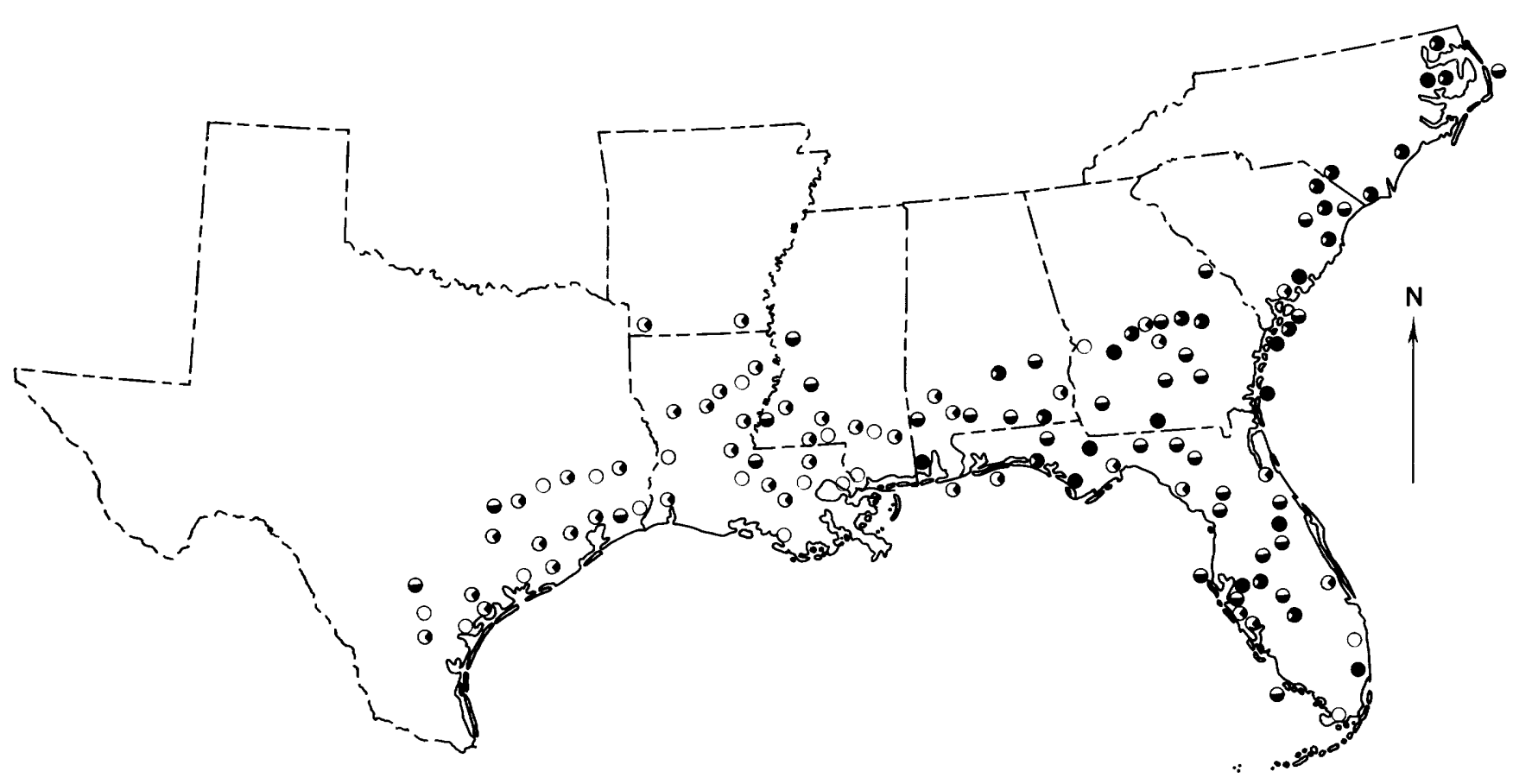

Symbol, and percentage of total samples
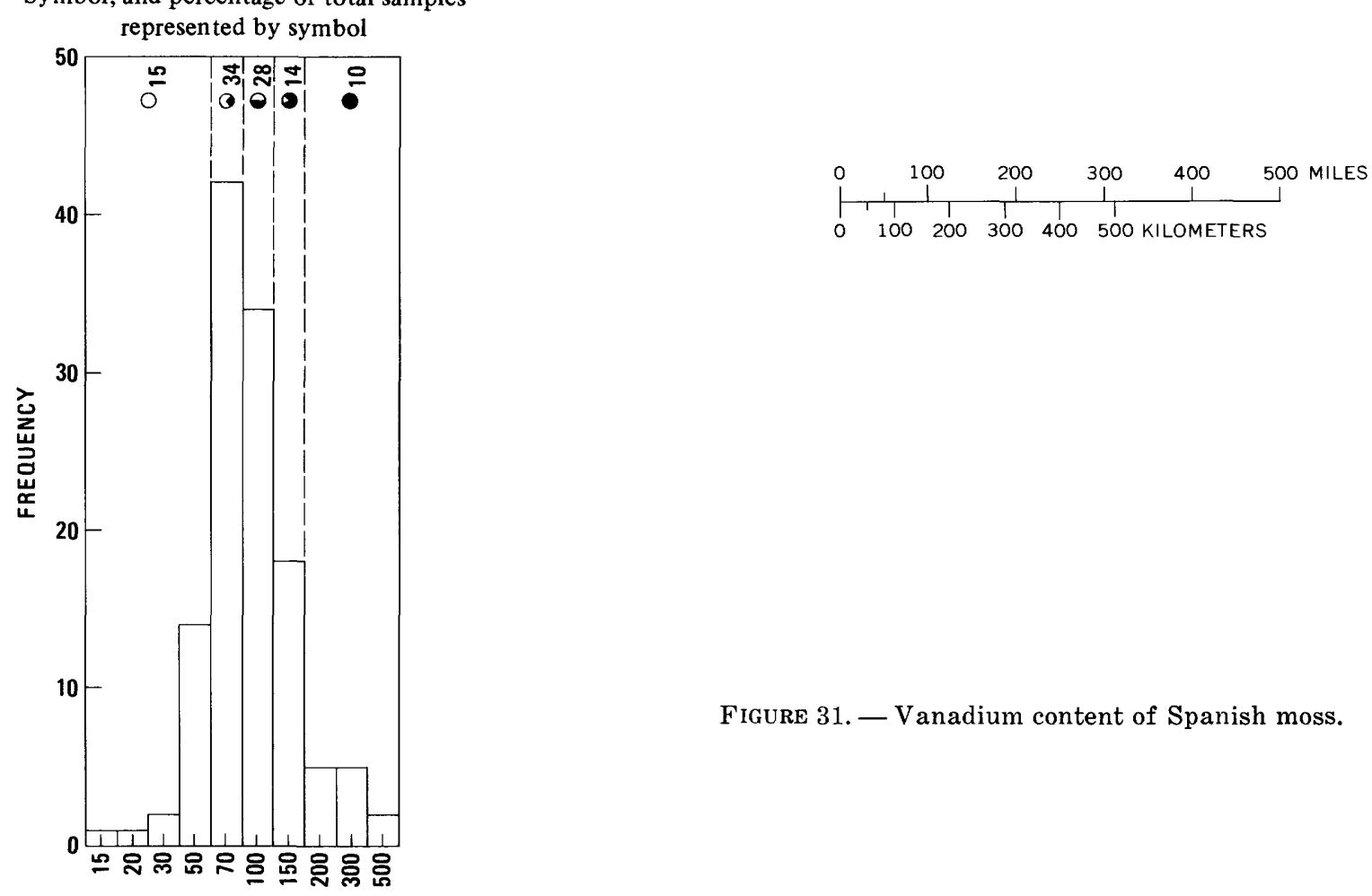

VANADIUM, IN PARTS PER MILLION IN ASH

Geometric mean, 91

Geometric deviation, 1.73

Number of samples and analyses, 123

Figure 31. - Vanadium content of Spanish moss. 


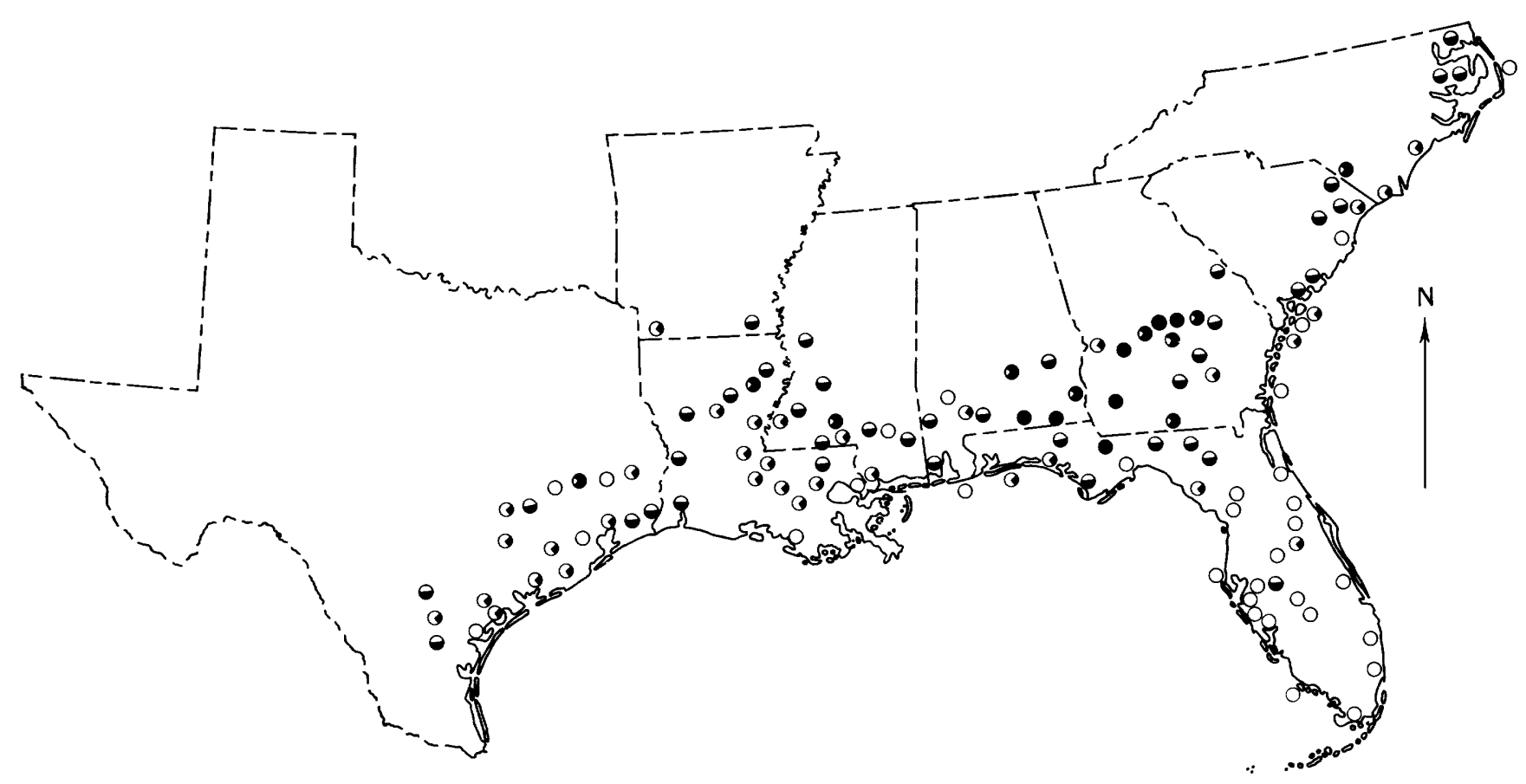

Symbol, and percentage of total samples represented by symbol
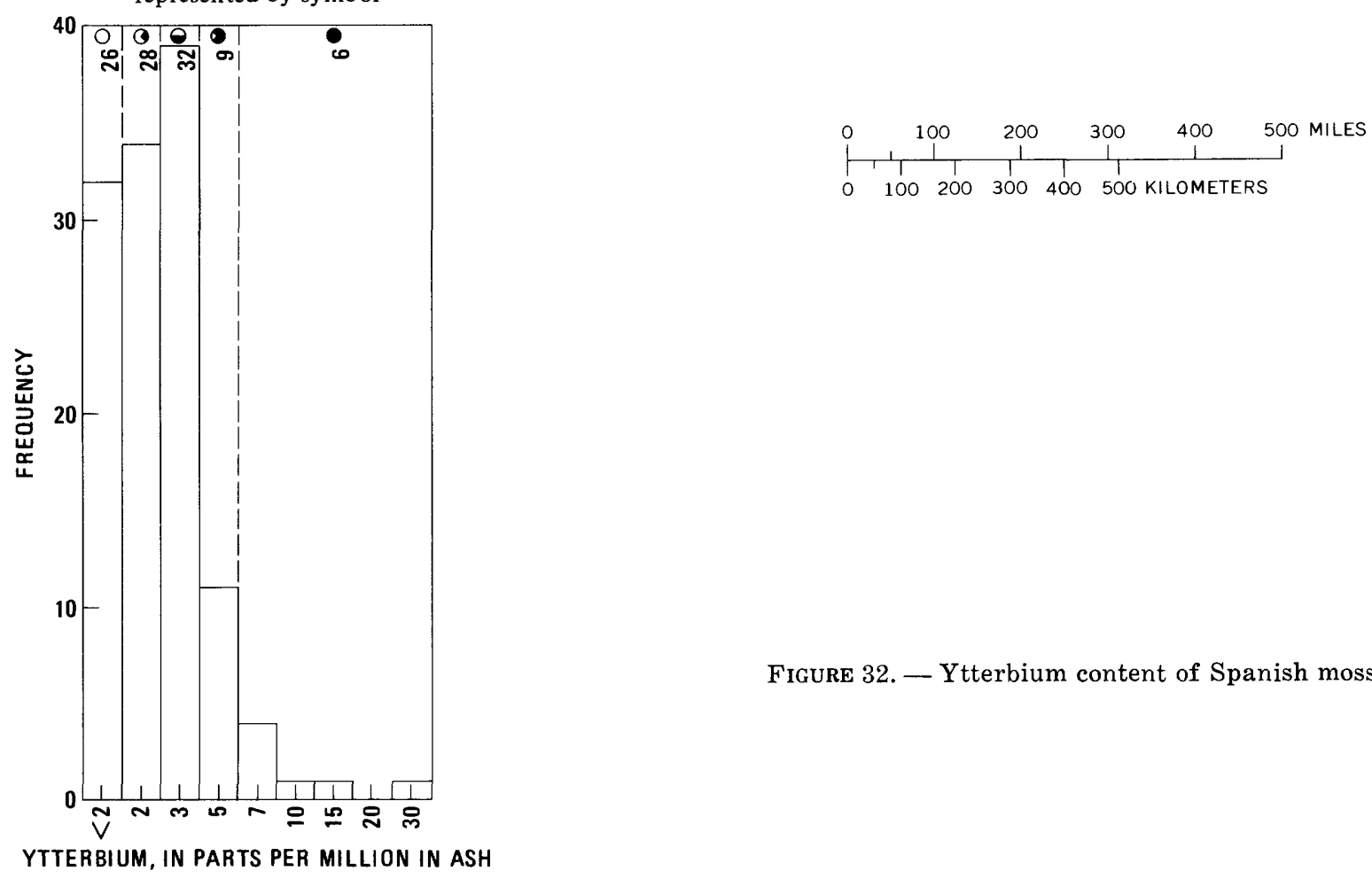

Geometric mean, 2.4

Geometric deviation, 1.81

Number of samples and analyses, 123 


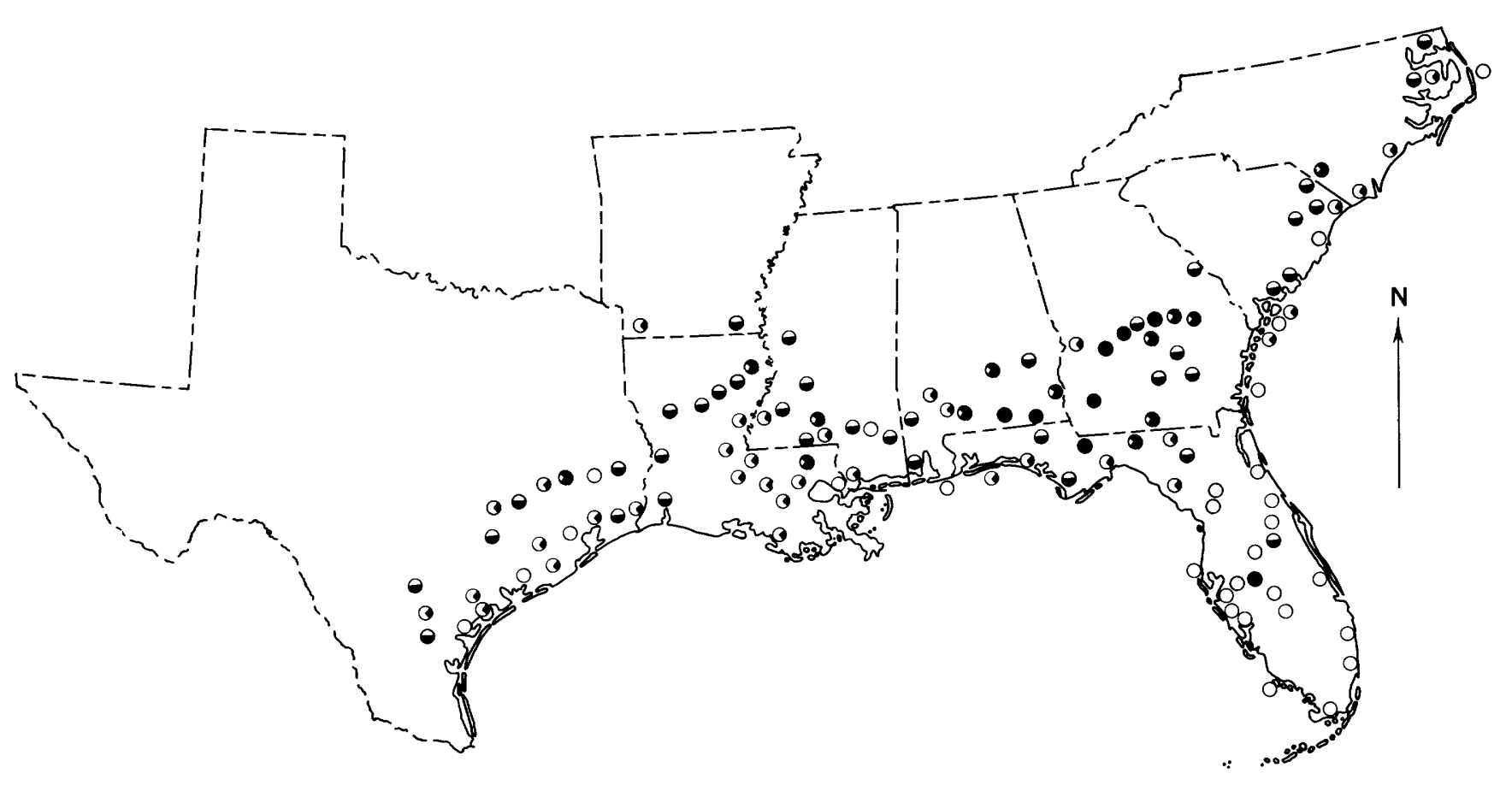

Symbol, and percentage of total samples
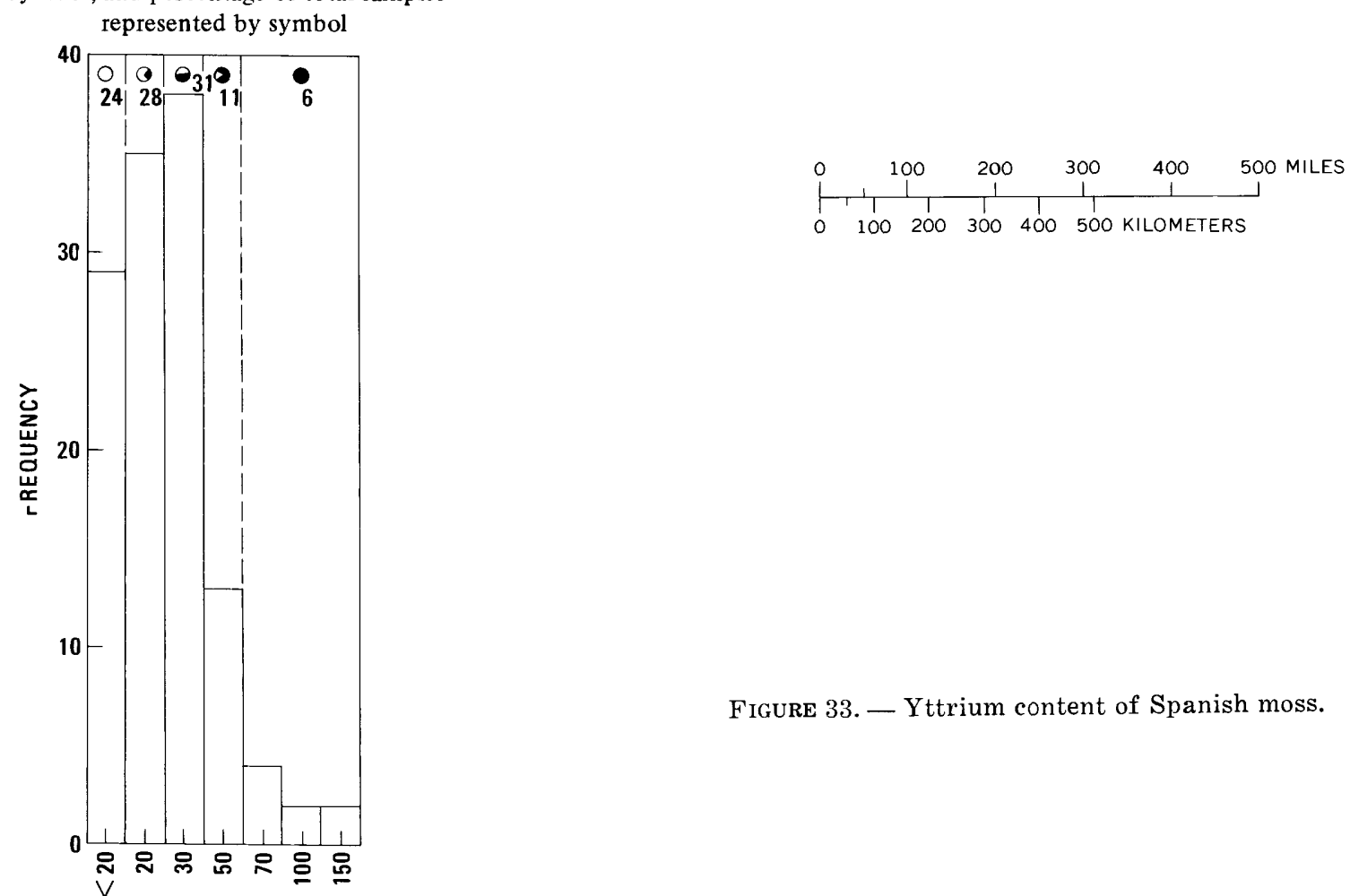

YTTRIUM, IN PARTS PER MILLION IN ASH

Geometric mean, 25

Geometric deviation, 1.78

Number of samples and analyses, 123

FIGURE 33. - Yttrium content of Spanish moss. 


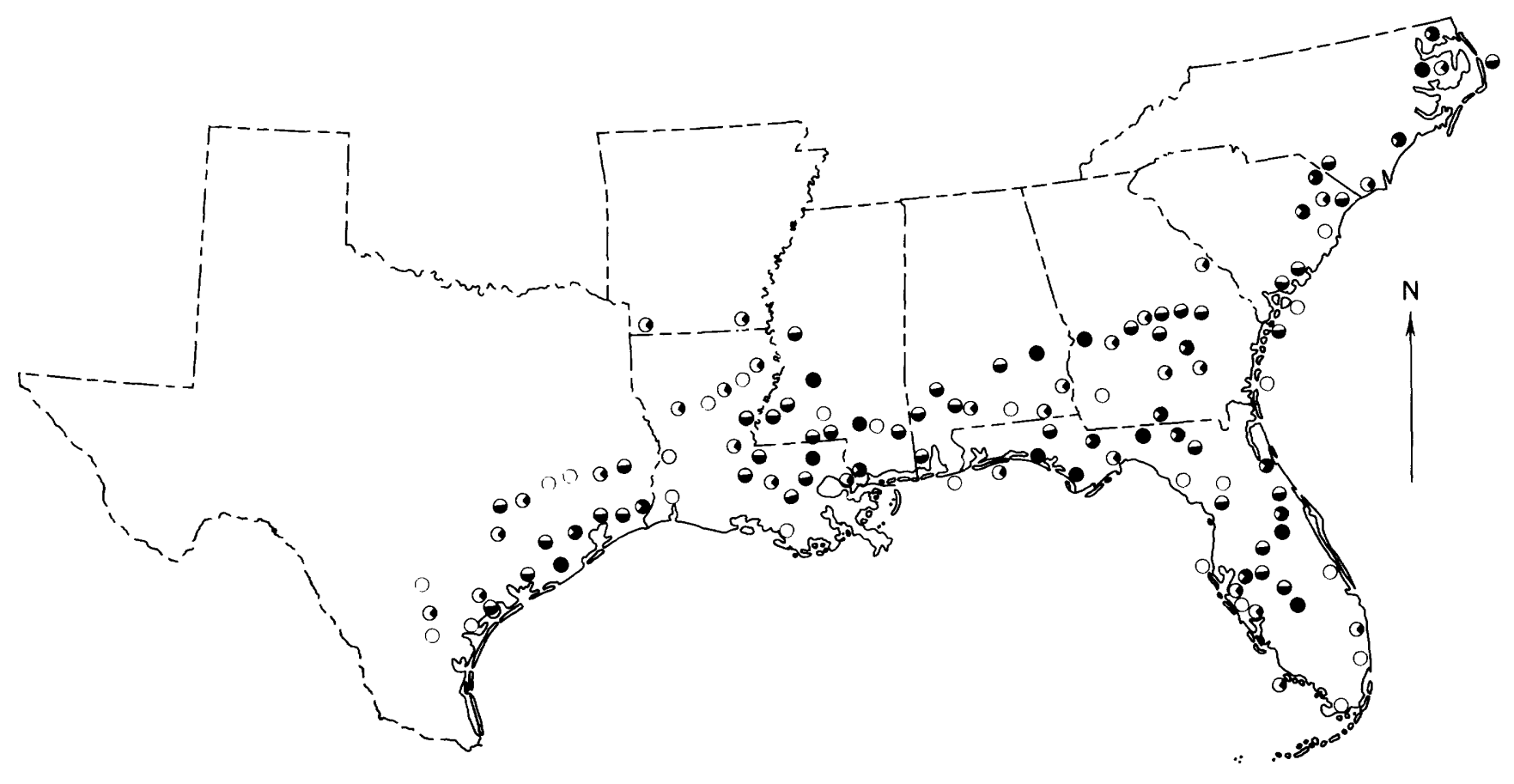

Symbol, and percentage of total samples represented by symbol
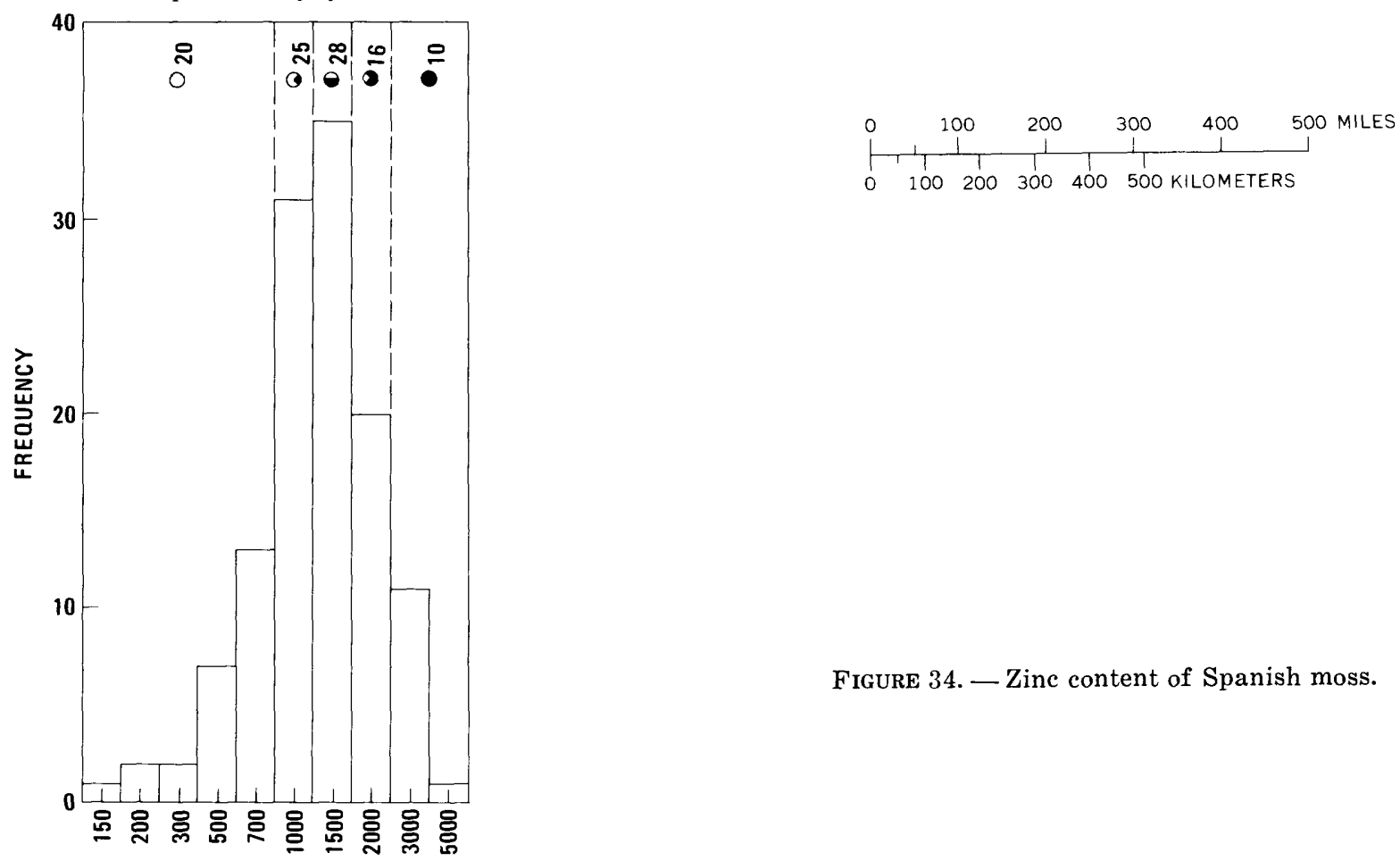

ZINC, IN PARTS PER MILLION IN ASH

Geometric mean, 1,235

Geometric deviation, 1.83

Number of samples and analyses, 123 


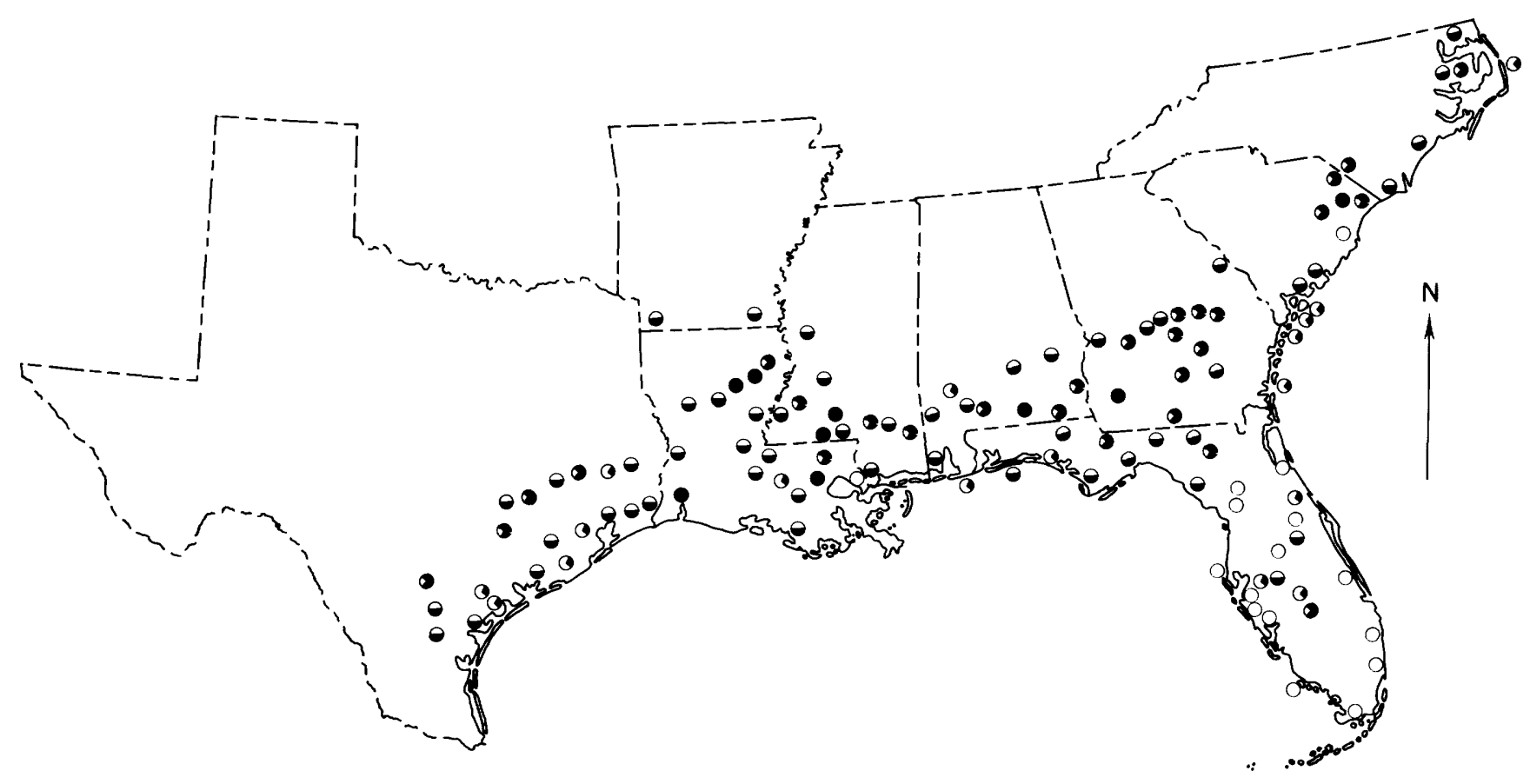

Symbol, and percentage of total samples represented by symbol
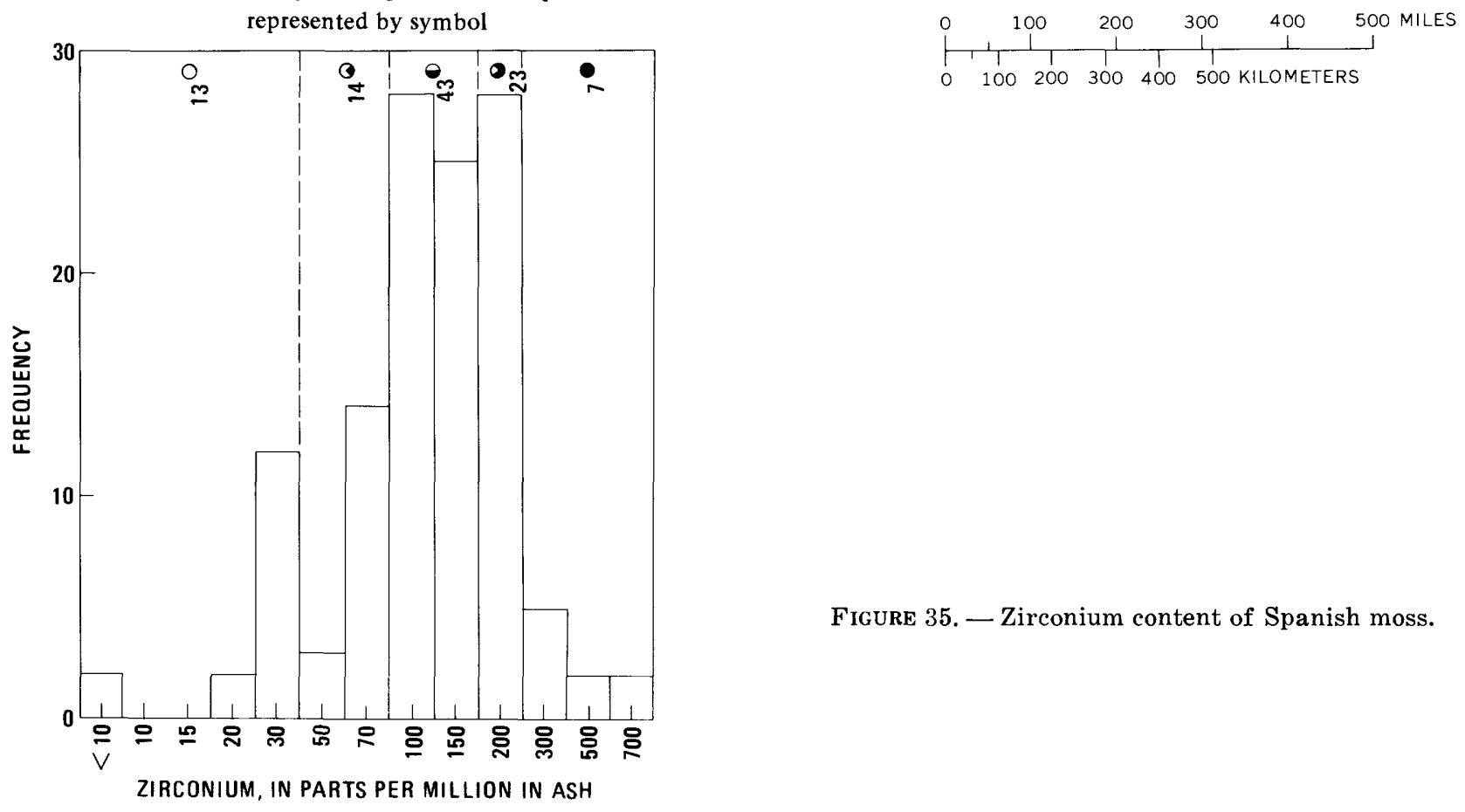

Figure 35. - Zirconium content of Spanish moss.

Geometric mean, 110

Geometric deviation, 2.12

Number of samples and analyses, 123 


\section{DISCUSSION OF RESULTS}

Although most species of flowering plants are believed to absorb only minor amounts of nutritive elements through their leaves (Fried and Broeshart, 1967, p. 119) and therefore must depend largely on absorption by roots, Spanish moss must obtain all nutritive elements by means of leaf and stem absorption. Some gases, including carbon dioxide, oxygen, sulfur dioxide (Berger, 1965, p. 232), chlorine (Berger, 1965, p. 248), and ammonia (Hutchinson and others, 1972), that come in contact with ordinary plant leaves are absorbed directly and are used in metabolic processes. These gases are thought to be similarly utilized by Spanish moss, although such utilization has not been proved experimentally. Particulate matter and materials in solution that become lodged on Spanish moss plants are analogous in function to the soil in which ordinary rooted plants grow. Analyses of Spanish moss samples reveal not only the chemical elements in the plant tissue but also those that are lodged on the plant surfaces, and the concentrations of elements in the two groups cannot be differentiated with certainty. Metabolic processes probably have only a minor effect on the concentrations of most elements discussed in this report. This effect may be largely the immobilization of certain nutritive elements in tissues of the plant, so loss of these elements through leaching by rainfall is reduced. However, both essential and nonessential elements may be held by chemical bonding to organic molecules in the plant, as was suggested by Goodman and Roberts (1971, p. 289 ). Therefore, the action of Spanish moss in accumulating airborne materials probably consists of more than simple atmospheric filtration.

Dissemination of Spanish moss occurs most commonly by wind transport of vegetative fragments of the plant rather than by seed dispersion. Most masses of Spanish moss that were collected as samples probably originated from such fragments, and for this and other reasons they cannot be traced back to their origins or ages as individual plants. A sample of Spanish moss, a perennial plant, is a composite of tissues of different ages, and there is no practical method of determining the age of the oldest tissue that is included. The increase in mass of a plant of this type tends to be exponential rather than linear; therefore, the samples are weighted to a substantial but unknown degree in favor of tissues of more recent growth. Although the effects of this loading cannot be measured readily, they must be considered in evaluating the role of this plant as an integrator of time increments of airborne materials.
For these reasons, analyses of Spanish moss samples probably reflect most strongly the atmospheric burdens of recent months or years, although some portion of a sample may be 10 or more years old.

In order to determine if the morphological and physiological features which adapt Spanish moss to an epiphytic habitat result in accumulations of kinds and amounts of elements different from the accumulations in ordinary soil-rooted (terrestrial) plants, comparisons can be made by using data that are now available. A study of the chemical composition of soil samples from 912 sites throughout the conterminous United States (Shacklette, Hamilton, Boerngen, and Bowles, 1971; Shacklette, Boerngen, and Turner, 1971) did not report analyses of the plants that were sampled concurrently with the soil samples. Summary analytical data for these plant samples and for Spanish moss samples are given in table 3.

The terrestrial plants that were sampled included a wide variety of life forms-trees, shrubs, broadleafed herbs, and grasses-as well as different plant parts. Element concentrations in these plant samples ranged widely; moreover, the suite of samples was heavily weighted in favor of woody plants (trees and shrubs). For these reasons, we believe that in comparing element concentrations in this heterogeneous group (terrestrial plants) with those of an entirely homogeneous group (Spanish moss), geometric mean values in Spanish moss are better compared with the central two-thirds ranges of the terrestrial plant analyses than with the geometric means.

The average percentages of ash obtained by burning dry plants of the two groups are very similar. However, the typical concentrations of aluminum, cobalt, chromium, gallium, iron, sodium, lead, titanium, vanadium, and zirconium in ash of Spanish moss samples exceed the upper limit of the expected 67percent range in ash of the soil-rooted plants. The extremely high concentrations of lead in Spanish moss undoubtedly reflect the fact that most samples were collected at sites near highways. Some samples of Spanish moss had a greater concentration of one or more of the elements chromium, copper, gallium, lead, vanadium, and zirconium than was found in any sample of soil-rooted plants. One sample of Spanish moss contained $15 \mathrm{ppm}$ germanium in ash, an element that is very rarely reported to occur in plants.

No element concentrations in Spanish moss were unusually low, although concentrations of the macronutrient elements potassium and phosphorus are near the lower end of the expected 67-percent range 
TABLE 3. - Chemical composition of Spanish moss samples and samples of soil-rooted plants from the conterminous United States

[Geometric means and ranges of elements reported as parts per million in ash. GM, geometric mean; GD, geometric deviation; ratio, number of samples in which the element was detected to total number of samples; ......, no data available

\begin{tabular}{|c|c|c|c|c|c|c|c|c|c|}
\hline \multirow[b]{2}{*}{$\begin{array}{l}\text { Element, } \\
\text { and ash }\end{array}$} & \multicolumn{4}{|c|}{ Spanish moss } & \multicolumn{5}{|c|}{ Soil-rooted plants } \\
\hline & GM & GD & Range & Ratio & GM & GD & Range & Ratio & $\begin{array}{l}\text { Central } \\
67 \text {-percent } \\
\text { range }\end{array}$ \\
\hline 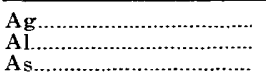 & $\begin{array}{r}41,000 \quad 0.12 \\
.79\end{array}$ & $\begin{array}{l}5.42 \\
2.21 \\
1.55\end{array}$ & $\begin{array}{l}<1-20 \\
1,500->1-2 \\
<100,000\end{array}$ & $\begin{array}{r}16: 123 \\
120: 123 \\
54: 116\end{array}$ & 6,500 & 3.52 & $<150-70$ & $\begin{array}{r}88: 1,125 \\
1,109: 1,117\end{array}$ & $1,900-23,000$ \\
\hline В & $\begin{array}{l}150 \\
560\end{array}$ & $\begin{array}{l}1.34 \\
2.32\end{array}$ & $\begin{array}{l}70-300 \\
50-2,000\end{array}$ & $\begin{array}{l}123: 123 \\
123: 123\end{array}$ & $\begin{array}{l}240 \\
390\end{array}$ & $\begin{array}{l}2.10 \\
3.75\end{array}$ & $\begin{array}{r}<30-3,000 \\
2-70,000\end{array}$ & $\begin{array}{l}1,135: 1,150 \\
1,151: 1,151\end{array}$ & $\begin{array}{l}110-500 \\
100-1,500\end{array}$ \\
\hline $\begin{array}{l}\text { Be } \\
\text { Bi }\end{array}$ & …. & ....... & ${ }^{12}$ & $3: 123$ & -..... & $\ldots \ldots$. & $\begin{array}{l}<2-100 \\
<20-30\end{array}$ & $\begin{array}{l}8: 1,153 \\
4: 1,125\end{array}$ & $\ldots \ldots$ \\
\hline Ca & 100,000 & 1.56 & $18,000-320,000$ & $123: 123$ & 120,000 & 2.69 & $1,600-430,000$ & $988: 988$ & $45,000-320,000$ \\
\hline $\begin{array}{l}\text { Cd } \\
\text { Ce }\end{array}$ & $\begin{array}{c}7.9 \\
\ldots \ldots .\end{array}$ & $\begin{array}{c}1.65 \\
\ldots \ldots .\end{array}$ & $\begin{array}{c}.8-27 \\
200-300\end{array}$ & $\begin{array}{r}122: 122 \\
3: 123\end{array}$ & $\ldots .$. & $\ldots \ldots \cdot$ & $1,000-1,500$ & $2: 1,117$ & $\cdots \cdots$. \\
\hline $\begin{array}{l}\text { Co } \\
\text { Cr. } \\
\text { Cu } \\
\text { Fe } \\
\text { Ga }\end{array}$ & $\begin{array}{c}9.8 \\
57 \\
150 \\
16,000 \\
10\end{array}$ & $\begin{array}{l}1.83 \\
1.73 \\
2.01 \\
1.87 \\
1.71\end{array}$ & $\begin{array}{c}<7-70 \\
7-1,500 \\
20-2,000 \\
1,000-50,000 \\
<7-50\end{array}$ & $\begin{array}{r}98: 123 \\
123: 123 \\
123: 123 \\
123: 123 \\
95: 114\end{array}$ & $\begin{array}{c}9.94 \\
100 \\
3,600 \\
.20\end{array}$ & $\begin{array}{l}5.83 \\
2.85 \\
1.98 \\
2.52 \\
9.83\end{array}$ & $\begin{array}{l}<5-300 \\
<1-700 \\
5-1,500 \\
100-70,000 \\
<3-30\end{array}$ & $\begin{array}{r}232: 1,122 \\
1,096: 1,139 \\
1,153: 1,153 \\
1,153: 1,153 \\
150: 1,105\end{array}$ & $\begin{array}{c}.16-5.5 \\
3.4-27 \\
51-200 \\
1,400-9,100 \\
.02-2.0\end{array}$ \\
\hline $\begin{array}{l}\mathrm{Ge} \\
\mathrm{Hg}^{2}\end{array}$ & ....... & $\ldots \ldots$. & $\begin{array}{l}115 \\
<.5-.7\end{array}$ & $\begin{array}{l}1: 123 \\
8: 116\end{array}$ & $\cdots \cdots$. & ...... & $\cdots . .$. & $\cdots \cdots \cdot$ & $\cdots \cdots$ \\
\hline K & 94,000 & 1.74 & $6,000-200,000$ & $123: 123$ & 130,000 & 1.82 & $8,800-450,000$ & $1,006: 1,006$ & $71,000-240,000$ \\
\hline La & 14 & 3.80 & $<50-150$ & $36: 123$ & ........ & ........ & $<50-1,500$ & $46: 1,125$ & ....... \\
\hline Li................................ & & 1.53 & $8-90$ & $122: 122$ & 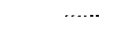 & $\cdots+.$. & $\ldots . .$. & ...... & $\cdots \cdots$ \\
\hline $\mathbf{M g}$ & 45,000 & 1.73 & $5,000-100,000$ & $123: 123$ & 30,000 & 2.05 & $1,000->100,000$ & $1,120: 1,153$ & $15,000-62,000$ \\
\hline $\begin{array}{l}\text { Mn } \\
\text { Mo }\end{array}$ & 2,300 & $\begin{array}{l}2.60 \\
1.80\end{array}$ & $\begin{array}{l}200-10,000 \\
<7-20\end{array}$ & $123: 123$ & 1,100 & 4.38 & $30-100,000$ & $1,153: 1,153$ & $250-4,800$ \\
\hline 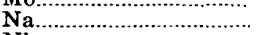 & $22,000^{3.7}$ & $\begin{array}{l}1.80 \\
4.05\end{array}$ & $1,100-240,000$ & $\begin{array}{rl}29 & 123 \\
123: 123\end{array}$ & $4,600^{4.2}$ & $\begin{array}{l}3.94 \\
4.00\end{array}$ & $400-360,000$ & $\begin{array}{l}459: 1,124 \\
277: 277\end{array}$ & $1,200-18,000$ \\
\hline Nb & ........... & & $15-20$ & $2: 123$ & ...... & ...... & ${ }^{1} 30$ & $1: 1,120$ & ....... \\
\hline 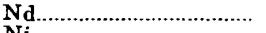 & 76 & 1.46 & ${ }^{1} 150$ & $4: 36$ & 32 & 6.21 & $<150-1,500$ & $11: 50$ & $5.2-200$ \\
\hline $\mathrm{Ni}$ & 39 & 1.74 & $7-200$ & $123: 123$ & 16 & 2.84 & $<5-500$ & $1,028: 1,139$ & $5.6-45$ \\
\hline $\begin{array}{l}\mathrm{P} \\
\mathrm{P}\end{array}$ & 9,400 & 1.55 & $2,400-48,000$ & $123: 123$ & 20,000 & 2.27 & $1,600-400,000$ & $991: 991$ & $8,800-45,000$ \\
\hline Pb.............. & 4,200 & 3.16 & $70-50,000$ & $123: 123$ & 86 & 6.17 & $<10-15,000$ & $980: 1,145$ & $14-530$ \\
\hline & & & $<0-20$ & $68: 100$ & ….. & $\cdots \cdots \cdot$ & $<7-30$ & $43: 1,153$ & $\cdots \cdots$ \\
\hline $\mathrm{Se}^{2} \ldots \ldots \ldots \ldots \ldots \ldots \ldots$ & & & ${ }_{1}$ & $4: 123$ & ...... & ....... & & & \\
\hline Sn & 21 & 1.80 & $20-30$ & $6: 123$ & 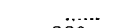 & & $<10-70$ & $22: 1,152$ & \\
\hline Sr & 700 & 1.85 & $100-7,000$ & $123: 123$ & 880 & 3.78 & $<10-20,000$ & $1,145: 1,152$ & $230-3,300$ \\
\hline 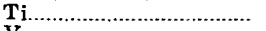 & 2,300 & 1.96 & $150-7,000$ & $123: 123$ & 260 & 3.49 & $<7-15,000$ & $1,122: 1,149$ & $75-910$ \\
\hline V & 91 & 1.73 & $15-500$ & $123: 123$ & 11 & 4.15 & $<7-300$ & $694: 1,123$ & $2.7-46$ \\
\hline $\mathbf{Y}$ & 25 & 1.78 & $<20-150$ & $94: 123$ & $\ldots \ldots$ & ....... & $<10-700$ & $161: 1,128$ & ....... \\
\hline 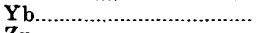 & & 1.81 & $<2-30$ & $91: 123$ & ...... & $\ldots \ldots$ & $<1-70$ & $101: 1,109$ & 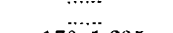 \\
\hline $\mathrm{Zn}_{\mathrm{n}}$ & 1,200 & 1.83 & $140-4,600$ & $123: 123$ & 450 & 2.73 & $<25-5,800$ & $642: 643$ & $170-1,235$ \\
\hline $\mathbf{Z r}$ & 110 & 2.12 & $<20-700$ & $121: 123$ & 14 & 3.45 & $<20-500$ & $470: 1,152$ & $4.1-48$ \\
\hline Ash, percent ${ }^{2} \ldots \ldots \ldots$ & 4.6 & 1.46 & $2.2-34$ & $123: 123$ & 5.3 & 1.98 & $.43-65$ & $1,152: 1,152$ & $2.7-11$ \\
\hline
\end{tabular}

${ }^{1}$ All analyses were the same in samples in which the element was detected.

All analyses were the same in samples in
?Analyses reported on dry weight basis.

for soil-rooted plants and concentrations of magnesium and calcium are nearer the center of the range. Cerium, potassium, and niobium were the only elements that occurred at lower levels in a Spanish moss sample than in any sample of soilrooted plants represented in table 3 .

The capability of Spanish moss to serve as a longterm integrator of local airborne element loads is suggested by data in figure 3. In most plant ash, tin generally occurs in concentrations below the limit of analytical detection, and tin was quantitatively recorded in only six of the 123 Spanish moss samples. Four of the six samples were collected in the Houston-Galveston area in Texas. Because all 123 samples were analyzed in a sequence randomized with respect to geographic location, the probability of four samples in a localized area containing detectable concentrations of tin by chance alone is quite small. We hypothesize, therefore, that the atmosphere in this area carries unusually high concentrations of tin. This hypothesis seems confirmed by the fact that a tin smelter, the only one in the United States, is located at Texas City, Tex. (Lewis, 1971, p. 1066), across the bay from Galveston.

In order to characterize possible differences in the local airborne element load, analyses of five samples from each of four kinds of areas, classified according to their principal economic uses, were examined, and the elements that occurred in concentrations greater than the geometric mean are shown in table 4. More complete descriptions of the sample localities are given in table 1.

Table 4 shows that high concentrations of arsenic, cadmium, chromium, cobalt, copper, lead, nickel, and vanadium in Spanish moss samples occur in areas where high rates of vehicular and industrial emissions are expected.

The influence of ocean spray on sodium concentrations in the samples is indicated in figure 28 . All samples (except one from Texas) that have greater-than-average sodium concentrations are from locations where airborne saltwater is expected 
TABLE 4. - Elements found in concentrations greater than average in Spanish moss samples from four kinds of sites

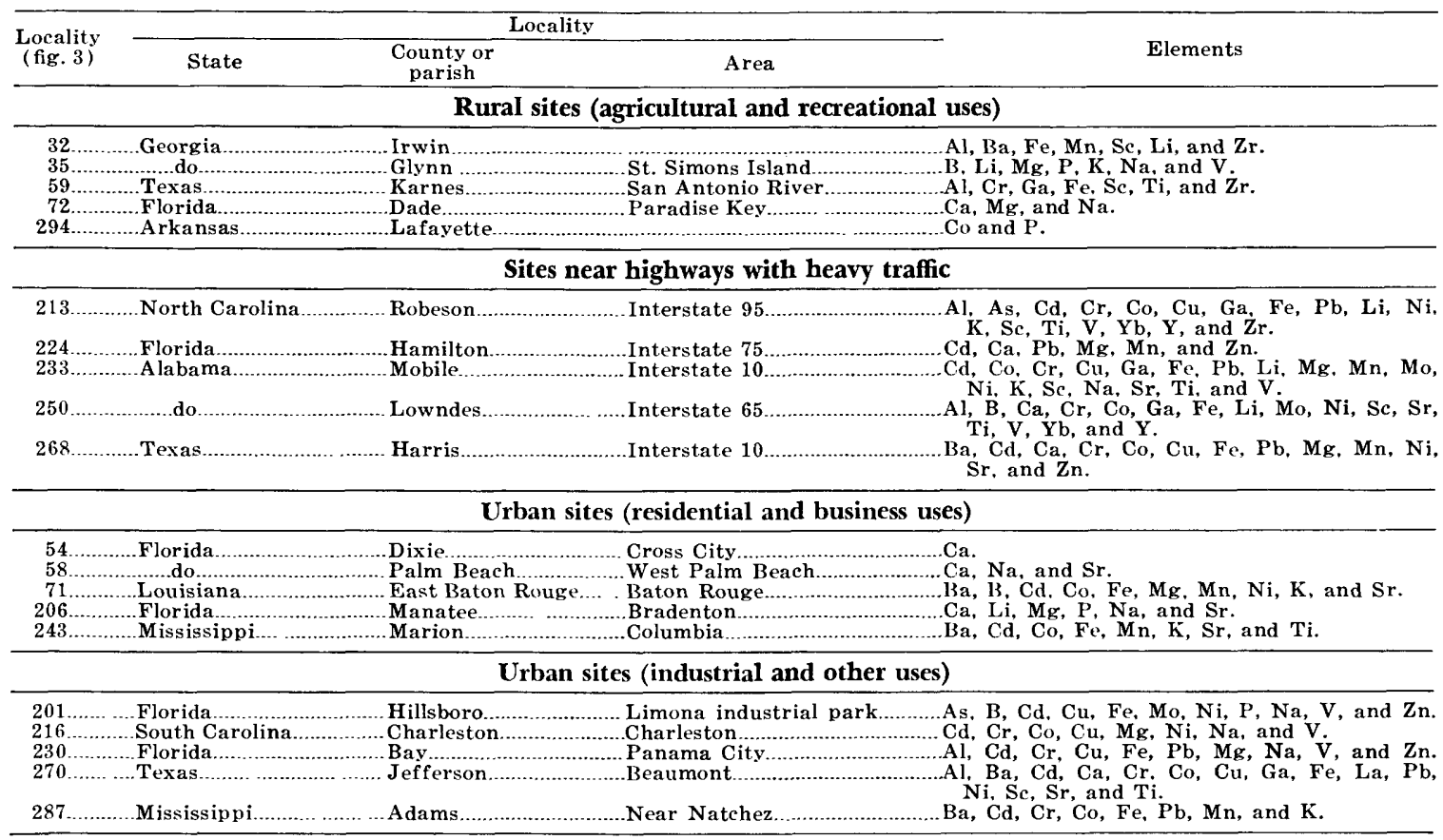

to be present at times, and no sample that contains less-than-average amounts of sodium is from such a location. Elements that are common constituents of soil dust, such as aluminum, calcium, magnesium, and iron, are found in samples from all areas.

Multivariate statistical analysis methods are being used to provide further interpretations of element distribution patterns in these Spanish moss samples, and the results of this study are planned to be presented in a subsequent paper.

\section{SUMMARY AND CONCLUSIONS}

1. Airborne chemical elements, which are accumulated by many species of plants, may contribute to the nutrition of the plant or may produce toxic effects. These elements are carried as gases, solutes, or particulate matter and may be actively or passively accumulated by the plant.

2. The concentration of airborne elements in the plant is thought to be determined by the concentrations present in air or airborne materials, the inherent ability of the plant to absorb the elements, the ratio of plant surface to total mass, and the length of time that the plant is exposed to the air.

3 . Perennial plants which have a high surfaceto-mass ratio and which have no direct connection to the soil by means of a conductive system are effective integrators of airborne materials over time.
Analyses of lichens, mosses, and Spanish moss have been used to estimate the degree of atmospheric contamination.

4. Elemental analyses of Spanish moss samples collected from rural, residential, highway, and industrial locations reflect significant differences in concentrations of metals. Samples from industrial and highway locations can be characterized as containing greater-than-average amounts of arsenic, cadmium, chromium, cobalt, copper, lead, nickel, and vanadium. The high levels of lead found in some samples from highway locations are especially noteworthy. Of 123 samples analyzed, only six were found to contain tin; four of these grew in the Houston-Galveston area and are believed to reflect the presence, in the area, of a tin smelter, the only one in the United States.

5. Many samples from sites near the seashore contained greater-than-average amounts of sodium that is thought to have been derived from ocean spray. Samples from rural locations commonly contain low concentrations of the metals usually associated with urban or industrial activities.

6. Results of this study indicate that elemental analysis of Spanish moss can be used as an economical and rapid method of estimating the kind and relative concentration of airborne chemical elements among locations over a period of months or years. 


\section{REFERENCES CITED}

Aso, K., 1909, Können Bromeliaceen durch die Schuppen der Blätter Salze aufnehmen? [Can plants in the Bromeliaceae family absorb salts through the leaf scales?]: Flora, v. 100 , p. $447-450$.

Benzing, D. H., and Renfrow, A., 1971, The nutrient status of populations in south Florida, part 1 of The biology of the epiphytic bromeliad Tillandsia circinata Schlect.: Am. Jour. Botany, v. 58 , no. 9 , p. 867-873.

Berger, K. C., 1965, Introductory soils: New York, Macnillan Co., $371 \mathrm{p}$.

Billings, F. H., 1904, A study of Tillandsia usneoides: Bot. Gaz., v. 38, p. 99-121.

Brewer, R. F., 1966, Fluorine, in Chapman, H. D., ed., Diagnostic criteria for plants and soils: California Univ., Div. Agr. Sci., p. 180-196.

Chilean Iodine Educational Bureau, 1956, Geochemistry of iodine: London, The Shenval Press, $150 \mathrm{p}$.

Cohen, A. C., Jr., 1961, Tables for maximum likelihood estimates - Singly truncated and singly censored samples: Technometrics, v. 3 , no. 4 , p. 535-541.

Egnér, H., 1965, Die Bedeutung der Schwefelverbindungen in der Luft für die Bodenfruchtbarkeit [The importance to soil fertility of sulfur compounds in the atmosphere]: Agrochimica, v. 9, no. 2, p. 133-143.

European Congress on the Influence of Air Pollution on Plants and Animals, 1969, Air pollution: European Cong. on Influence of Air Pollution on Plants and Animals, 1st, Wageningen, The Netherlands, 1968, Proc., $415 \mathrm{p}$.

Fried, Maurice, and Broeshart, Hans, 1967, The soil-plant system in relation to inorganic nutrition: New York and London, Academic Press, 358 p.

Garber, K., 1968, Über den Fluorgehalt der Pflanzen [The fluorine content of plants], in Fluor-Wirkungen - Forschungsergebnisse bei Pflanze und Tier [Fluorine effects -Results of research with plants and animals]: Wiesbaden, Franz Steiner Verlag, Inv. Rept. 14, p. 42-48.

Garber, K., Guderian, R., and Stratmann, H., 1968, Untersuchungen über die Aufnahme von Fluor aus dem Boden durch Pflanzen [Investigations on the uptake of fluorine from the soil by plants], in Fluor-Wirkungen - Forschungsergebnisse bei Pflanze und Tier [Fluorine effects -results of research with plants and aninals]: Wiesbaden, Franz Steiner Verlag, Inv. Rept. 14, p. 28-41.

Garth, R. E., 1964, The ecology of Spanish moss (Tillandsia usneoides) - Its growth and distribution: Ecology, v. 45, no. 3 , p. 470-481.

Goodman, G. T., and Roberts, T. M., 1971, Plants and soils as indicators of metals in the air: Nature, v. 231, no. 5301, p. 287-292.

Holley, W. D., 1965, The CO.z story, in Ball, Vic, ed., The Ball Red Book [11th ed.]: Chicago, Geo. J. Ball, Inc., p. 94-98.

Hutchinson, G. L., Millington, R. J., and Peters, D. B., 1972, Atmospheric ammonia - absorption by plant leaves: Science, v. 175, no. 4023 , p. 771-772.

Ingham, G., 1950, The mineral content of air and rain and its importance to agriculture: Jour. Agr. Sci., v. 40, p. 55-61.

Jaakkola, Timo, Takahashi, Hiroshi, and Miettinen, J. K., 1971, Cadmium content in sea water, bottom sediment, fish, lichen and elk in Finland: in Trace elements in relation to cardiovascular disease: World Health Organiza- tion Mtg. Rept., Geneva, Switzerland, Feb. 8-13, 1971, $16 \mathrm{p}$.

Lewis, J. R., 1971, Tin: U.S. Bur. Mines Minerals Yearbook 1969 , v. 1-2, p. 1065-1080.

LeBlanc, Fabius, 1969, Epiphytes and air pollution, in Air pollution: European Cong. on Influence of Air Pollution on Plants and Animals, 1st, Wageningen, The Netherlands, 1968, Proc., p. 211-221.

MacIntire, W. H., Hardin, L. J., and Hester, Winnifred, 1952, Measurement of atmospheric fluorine - Analyses of rain waters and Spanish moss exposures: Indus. Eng. Chemistry, v. 44, no. 6 , p. 1365-1370.

Malo, B. A., and Purvis, E. R., 1964, Soil absorption of atmospheric ammonia: Soil Sci., v. 97, p. 242-247.

Martinez, J. D., Nathany, Madhusudan, and Dharmarajan, Venkatram, 1971, Spanish moss, a sensor for lead: Nature, v. 233, no. 5321, p. 564-565.

Miesch, A. T., 1967, Methods of computation for estimating geochemical abundance: U.S. Geol. Survey Prof. Paper, $574-\mathrm{B}, 15 \mathrm{p}$.

Myers, A. T., Havens, R. G., and Dunton, P. J., 1961, A spectrochemical method for the semiquantitative analysis of rocks, minerals, and ores: U.S. Geol. Survey Bull. 1084-I, p. 207-229.

Nylander, M. W., 1866, Les Lichens du Jardin du Luxembourg [The lichens of the Luxembourg Garden]: Soc. Bot. France, v. 13, p. 364-372.

Osburn, W. S., Jr., 1963, The dynamics of fallout distribution in a Colorado alpine tundra snow accumulation ecosystem, in Schultz, Vincent, and Klement, A. W., Jr., eds., Radioecology - National symposium on radioecology, 1st, Colorado, 1961, Proc.: New York, Reinhold Publishing Corp., p. 51-71.

Riehm, H., 1965, Pflanzennährstoffe in den atmosphärischen Niederschlägen unter besonderer Berücksichtigung des Schwefels [Plant nutrients in atmospheric precipitation, with particular reference to sulfur], in Lo zolfo in agricoltura-Atti del V Simposio Internazionale di Agrochimica, Palermo, 1964: Inst. di Chimica Agraria, Collana della rivista "Agrochimica," 7, p. 453-472.

Rühling, Åke, 1969, Tungmetallföroreningar inom Oskarshamnsomradet [Heavy metal pollution within the limits of the Oskarshamn area]: Forskningsrapport, Ekologiska tungmetallundersökningar, Avd. för ekologisk botanik, Lunds Universitet, 11 p.

1971, Tungmetallföroreningar inom Stor-Stockholmsområdet [Heavy metal pollution within the limits of the Greater Stockholm area]: Rapport nr. 25 från ekologiska tungmetallundersökningar, Avd. för ekologisk botanik, Lunds Universitet, $34 \mathrm{p}$.

Rühling, Åke, and Tyler, Germund, 1968, An ecological approach to the lead problem: Botaniska Notiser, v. 121, p. 321-342.

1969 , Ecology of heavy metals - a regional and historical study: Botaniska Notiser, v. 122, p. 248-259.

1971, Regional differences in the deposition of heavy metals over Scandinavia: Jour. Appl. Ecology, v. 8, p. 497-507.

Shacklette, H. T., 1972, Cadmium in plants: U.S. Geol. Survey Bull. 1314-G, 28 p.

Shacklette, H. T., and Cuthbert, M. E., 1967, Iodine content of plant groups as influenced by variation in rock and 
soil type, in Cannon, H. L., and Davidson, D. F., eds., Relation of geology and trace elements to nutrition - A symposium, New York, 1963: Geol. Soc. America Spec. Paper 90, p. 31-46.

Shacklette, H. T., Boerngen, J. G., and Turner, R. L., 1971, Mercury in the environment - Surficial materials of the conterminous United States: U.S. Geol. Survey Circ. 644, $5 \mathrm{p}$.

Shacklette, H. T., Hamilton, J. C., Boerngen, J. G., and Bowles, J. M., 1971, Elemental composition of surficial materials in the conterminous United States: U.S. Geol. Survey Prof. Paper 574-D, 71 p.

Shacklette, H. T., Sauer, H. I., and Miesch, A. T., 1970, Geochemical environments and cardiovascular mortality rates in Georgia: U.S. Geol. Survey Prof. Paper 574-C, 39 p.

Sloover, Jacques De, and LeBlanc, Fabius, 1968, Mapping of atmospheric pollution on the basis of lichen sensitivity, in Misra, R., and Gopal, B., eds., Symposium on recent advances in tropical ecology, 1968, Proc.: Varanasi-5, India, Internat. Soc. Tropical Ecology, pt. 1, p. 42-56.
Sower, F. B., Eicher, R. N., and Selner, G. I., 1971, The STATPAC system: [U.S.] Geol. Survey Computer Contr. $11,36 \mathrm{p}$.

Watson, D. C., Hanson, W. C., Davis, J. J., and Rickard, W. H., 1966, Radionuclides in terrestrial and freshwater biota, chap. 42 in Wilimovsky, N. J., and Wolfe, J. N., eds., Environment of the Cape Thompson region, Alaska: U.S. Atomic Energy Comm., p. 1165-1200; available only from U.S. Dept. Commerce, Natl. Tech. Inf. Service, Springfield, Va. 22151, as Rept. PNE-481.

Wherry, E. T., and Buchanan, Ruth, 1926, Composition of the ash of Spanish-moss: Ecology, v. 7, no. 3, p. 303-306.

Wherry, E. T., and Capen, R. G., 1928, Mineral constituents of Spanish-moss and Ballmoss: Ecology, v. 9, no. 4, p. 501-504.

Wöhlbier, W., 1968, Zusammenfassung und Ausblick [Summary and outlook], in Fluor-Wirkungen - Forschungsergebnisse bei Pflanze und Tier [Fluorine effects - results of research with plants and animals]: Wiesbaden, Franz Steiner Verlag, Inv. Rept. 14, p. 142-147. 